\title{
ESTRUTURA GENÉTICA DE POPULAÇÕES NATURAIS DE Chorisia speciosa St. Hil. (BOMBACACEAE) EM FRAGMENTOS FLORESTAIS NA REGIÃO DE BAURU (SP) - BRASIL
}

\section{LINA MARIA FARINA INGLEZ DE SOUZA}

Engenheira Agrônoma

Orientador: Prof. Dr. Paulo Yoshio Kageyama

\begin{abstract}
Dissertação apresentada à Escola Superior de Agricultura "Luiz de Queiroz”, Universidade de São Paulo para obtenção do título de mestre em Ciências, Área de Concentração: Ciências Florestais.
\end{abstract}

P I R A C I C A B A

Estado de São Paulo - Brasil

Julho de 1997 
Dados Internacionais de Catalogação na Publicação (CIP) DIVISÃO DE BIBLIOTECA E DOCUMENTAÇÃO - Campus "Luiz de Queiroz"/USP

Souza, Lina Maria arina Inglez de Estrutura enética de populaçōes naturais de Chorisia speciosa St. Hil. (Bombacaceae) em fragmentos florestais na regiāo de Bauru (SP) - Brasil / Lina Maria Farina Inglez de Souza. - - Piracicaba, 1997.

$76 \mathrm{p}$.

Dissertaçāo (mestrado) - - Escola Superior de Agricultura Luiz de Queiroz, 1997. Bibliografia.

1. Diversidade genética 2. Genética florestal 3. Paineira 4. Populaçāo 5. Reserva Estadual de Bauru 6. Sucessão florestal I. Título 


\section{ESTRUTURA GENÉTICA DE POPULAÇÕES NATURAIS DE Chorisia speciosa St. Hil. (BOMBACACEAE) EM FRAGMENTOS FLORESTAIS NA REGIÃO DE BAURU (SP) - BRASIL}

LINA MARIA FARINA INGLEZ DE SOUZA

Aprovada em: 01/09/1997

Comissão julgadora:

Prof. Dr. Paulo Yoshio Kageyama

ESALQ/USP

Prof. Dr. Roland Vencovsky

ESALQ/USP

Prof. Dr. Mário Luiz Teixeira de Moraes

FEIS/UNESP

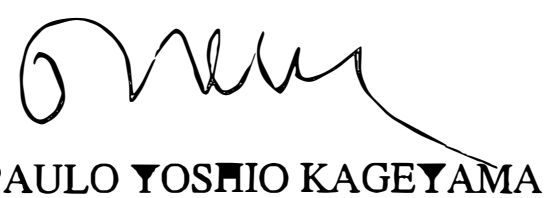

Prof. Dr. PAULO YOSHIO KAGE YAMA

Orientador 
Dedico aos meus pais Marcelo e Edina e aos meus irmãos Ana e Marcelinho, cujo o exemplo de otimismo e coragem me ensinou a perseverar sempre.

Ao meu marido Ari e à minha filha Ana Teresa, duas jóias raras, que me inspiraram e me apoiaram, com todo meu amor e gratidão eu ofereço. 


\section{AGRADECIMENTOS}

A concretização deste trabalho só foi possível pela profunda bondade de inúmeras pessoas, que de alguma forma se dispuseram a colaborar. Agradeço à todas. Em especial;

- Ao mestre e acima de tudo amigo professor Dr. Paulo Yoshio Kageyama, que foi muito além da orientação científica e me ajudou a formar valores éticos, me estimulou a militar em prol das causas ambientais, me ofereceu oportunidades de trabalho e me apoiou como irmão em momentos difíceis. O destino me foi generoso, pois na busca de um orientador eu encontrei também um integrante da minha "tribo".

- Ao Professor Dr. Roland Vencovsky pelos valiosos ensinamentos e discussões.

- Ao bom e querido Enciclopedista Julio Seabra Inglez de Sousa ("Vô Julio"), meu maior incentivador, que me ajudou muito em todas as etapas deste trabalho, espiritual, científica e materialmente. Infinitos agradecimentos.

- Aos amigos e "co-autores" deste estudo, que dedicaram uma boa parte de seus preciosos tempos para me ajudar a pensar e a entender o conteúdo deste trabalho: Nadja Lepsch-Cunha, Flávio B. Gandara, Pedro Moraes e Alexandre Magno Sebben.

- Ao Instituto Florestal (Bauru), especialmente à Ana Cristina Siqueira, que me proporcionou todo suporte para o desenvolvimento da fase do campo.

- Ao DEPRN (Bauru), especialmente ao Ernani Bevenutti, que sacrificou o feriado de Carnaval para "caçar" paineiras em fragmentos florestais.

- Aos professores Mário Moraes, Edson Mori e Maurício Reis pelos ensinamentos e sugestões.

- Ao Departamento de Isótopos Estáveis - CENA, pelo apoio técnico.

- Ao CNPq e à FAPESP pelo apoio financeiro.

- À todos os funcionários do Departamento de Ciências Florestais / ESALQ-USP. 
- Aos "colegas de eletroforese" que por suas amizades e espírito de solidariedade tornaram mais leve a árdua jornada de trabalho no laboratório: Elza M. Ferraz, Helena Maltez, Cristina Lacerda, Gelson e Veridiana.

- À equipe de campo mais eficiente e divertida: Rê, Edu, Úrsula, Zé Cardoso, sr. Osni e Sr. Adolpho.

- Ao pessoal do IPEF (Setor de Sementes e Viveiro) pelo apoio irrestrito nas fases de campo: Israel, Amarildo, Zé Cardoso, Chico, Zé Falafina, e Peterson. Sem eles, a matéria prima deste trabalho (sementes e mudas) não teria sobrevivido.

- À todos os colegas da pós-graduação pelo carinho e amizade.

- Aos meus irmãos-espirituais: Renata Mauro Freire, Carmen Lúcia Rodrigues (Calú), Ulisses Monte, Renata Evangelista (Renatinha), Dirce Lacôrte e Maria Teresa lacôrte.

- Aos meus "anjos da guarda": Lia, Rô, José e Cida. O trabalho de vocês foi imprescindível e maravilhoso.

- Ao amigo Vitor J. M. Oliveira e ao Jesuíno (Topografia) pela competência na elaboração de mapas e edição de textos.

- À todos os seres sagrados, Buddhas, Bodhisattvas, Protetores do Dharma que há muitos eons vêem me guiando.

OM MANI PAME HUM 
Como a paina que o vento leva

Vão nossos desejos

Amores

Rancores

Pesares

Prazeres

Encontros

O Saber

Para onde vai?

Para além

Alcançar alguém

Que o entenda e transforme

Em luz

Em paz

Em amor

Em criação

Como a Paina que o vento leva

E carrega uma semente

Que dorme

Acorda em Solo

E cria outra vida. 


\section{SUMÁRIO}

Página

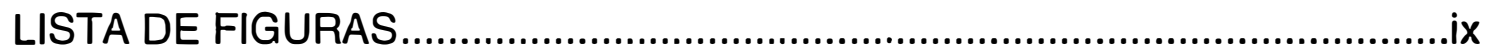

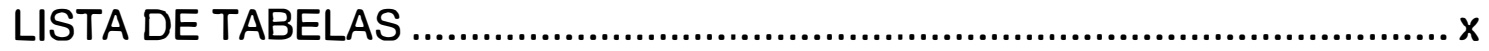

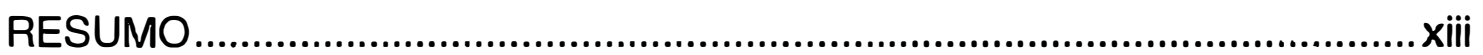

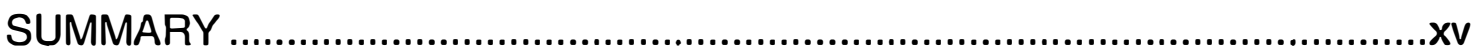

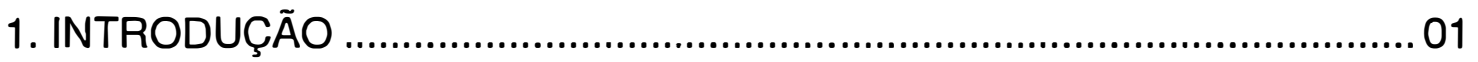

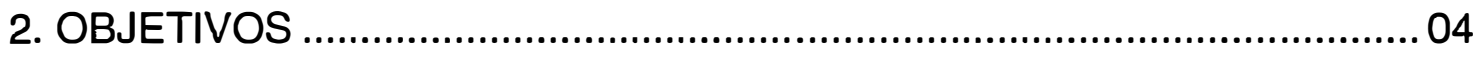

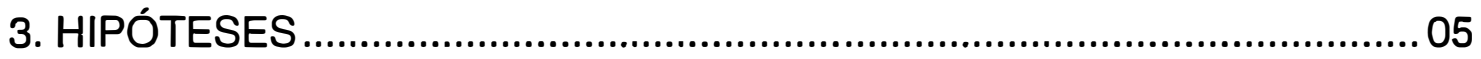

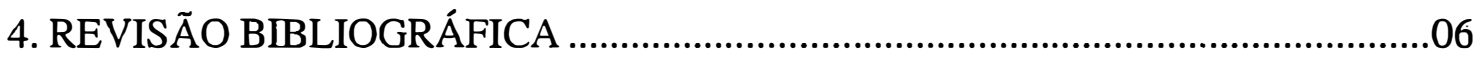

4.1. A espécie Chorisia speciosa St Hil.........................................................

4.2. Estudos de variação genética em populações naturais ...............................10

4.3. Fragmentação florestal e suas consequiências genéticas..............................12

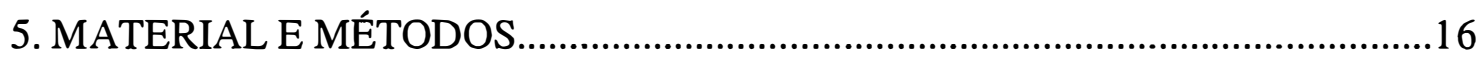

5.1. Caracterização dos locais de estudo ..........................................................16

5.2. Levantamento das populações, coleta de materiais e produção

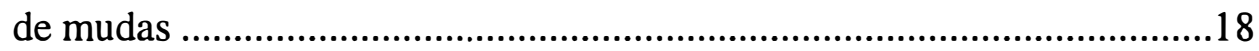

5.3. Eletroforese de Isoenzimas ......................................................................19

5.3.1. Testes preliminares.....................................................................19

5.3.2. Extração das isoenzimas...............................................................20

5.3.3. Preparo do tampão de gel e tampão de eletrodo ............................21

5.3.4. Sistemas isoenzimáticos testados ..................................................21 


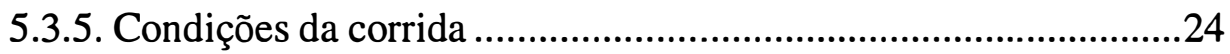

5.3.6. Leitura dos zimogramas............................................................25

5.4. Metodologia utilizada para fragmentação de população da reserva..........25

5.5. Metodologia estatística ..............................................................................30

5.5.1. Caracterização da variação genética..............................................30

5.5.2. Determinação da taxa de cruzamento ...........................................32

5.5.3. Estrutura genética espacial ..........................................................33

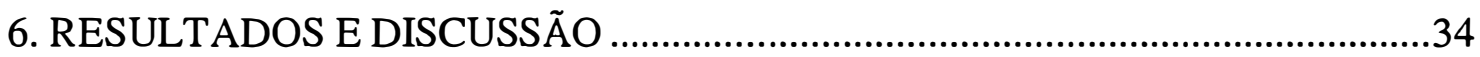

6.1. Estrutura genética da população situada na Estação Ecológica

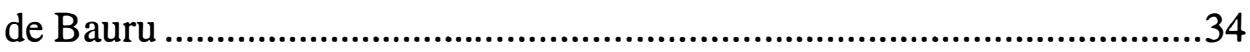

6.1.1. Distribuição espacial.......................................................................34

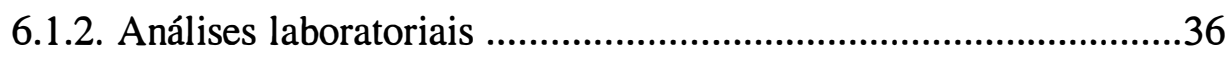

6.1.3. Interpretação genética dos zimogramas ...........................................36

6.1.4. Análise da variação genética ........................................................39

6.1.5. Taxa de cruzamento.........................................................................44

6.1.6. Estrutura genética espacial ...........................................................46

6.2. Estrutura genética em populações fragmentadas ......................................53

6.2.1. Estrutura genética de subpopulações artificiais originadas da Estação Ecológica de Bauru (Reserva) ..........................................53

6.2.2. Estrutura genética em fragmentos florestais de diferentes tamanhos e níveis de perturbação ...................................................58

6.2.2.1. Amostragem de campo e genética..................................58

6.2.2.2. Diversidade genética .........................................................60

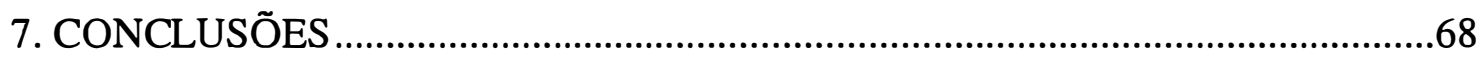

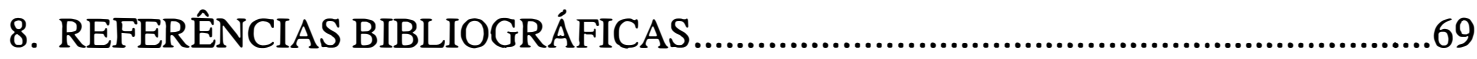




\section{LISTA DE FIGURAS}

1. Distribuição espacial da categoria I com 4 subpopulações: Subpopulação $1=13$ árvores, Subpopulação $2=13$ árvores, Subpopulação $3=14$ árvores, Subpopulação $4=13$ árvores, simulando o corte de $75 \%$ das árvores.

2. Distribuição espacial da categoria II com 2 subpopulações: Subpopulação $1=26$ árvores, Subpopulação $2=27$ árvores, simulando o corte de 50\% da população original.

3. Distribuição espacial da categoria III com 1 subpopulação $=29$ árvores, simulando o corte das árvores com DAP $>60 \mathrm{~cm}$. 29

4. Localização dos 53 indivíduos adultos de C. speciosa na área de estudo.

5. Esquema dos zimogramas dos padrões eletroforéticos oriundos de uma população natural de C. speciosa, para 9 locos e 6 sistemas enzimáticos.

6. Correlogramas para: Lap-1 alelo 1 e Mdh-3 alelo 1, para 9 classes de distância (eixo $x$ ) e os índices I de Moran (eixo y), em uma população natural de $C$. speciosa $(*$ significativo a $1 \% ; * *$ significativo a $5 \%)$.......49

7. Correlogramas para: Pgi-1 alelo 1, Pgi-1 alelo 2, Pgi-1 alelo 3 e Pgm-1 alelo 1, para 9 classes de distância (eixo $x$ ) e índices I de Moran (eixo $y$ ), em uma população natural de $C$. speciosa. .50

8. Correlogramas para: Pgm-1 alelo 2, Po-1 alelo 1, Po-2 alelo 1 e Média para 9 classes de distância (eixo $x$ ) e índices I de Moran (eixo $y$ ), em uma população natural de $C$. speciosa

9. Esquema dos fragmentos amostrados, com suas respectivas áreas, distâncias entre fragmentos e número de indivíduos. .59 


\section{LISTA DE TABELAS}

Tabela 1. Ocorrência de Chorisia speciosa em florestas mesófilas semidecíduas do interior do Estado de São Paulo, baseado em levantamentos fitossociológicos.

Tabela 2. Frequiências alélicas e índices de diversidade genética para adultos e famílias de uma população natural C. speciosa situada na Reserva, baseadas em 9 locos e seis sistemas enzimáticos (os números entre parênteses referem-se aos desvios padrões).

Tabela 3. Estimativa de parâmetros genéticos relativos a algumas esécies arbóreas que pertencem à família Bombacaceae. 41

Tabela 4. Teste qui-quadrado e exato de Fisher para os desvios do equilíbrio de Hardy Weinberg, considerando números observados (no) e esperados (ne) dos genótipos não agrupados ( $x^{2}$ nagrup), ou agrupados ( $x^{2}$ agrup.) em 3 classes para adultos e progênies de $C$. speciosa. $\mathrm{P}$ é a probabilidade do teste de Fisher. 43

Tabela 5. Estimativas da taxa de cruzamento multiloco $\left(\mathrm{t}_{\mathrm{m}}\right)$ para cada família, média referente a 26 famílias e taxa de cruzamento uniloco média $\left(\mathrm{t}_{\mathrm{s}}\right)$ para uma população natural de C. speciosa situada na Reserva Estadual de Bauru. O valor entra parênteses corresponde ao desvio padrão da média. 45

Tabela 6. Coeficientes de autocorrelação espacial (índice I de Moran) de uma população natural de Chorisia speciosa, para 2 métodos de pareamento de indivíduos: vizinho mais próximo ( $\left.\mathrm{I}_{\mathrm{vmp}}\right)$ e conexão de Gabriel $\left(\mathrm{I}_{G}\right)$, distância média entre indivíduos pareados e número de comparações. .. 47

Tabela 7. Coeficientes de autocorrelacão espacial (coeficiente I de Moran) em uma populacão natural de $C$. speciosa, para 9 classes de distância ${ }^{(1)}, 9$ alelos e número de comparações. 48 
Tabela 8. Índices de diversidade genética de subpopulações (Sp) criadas artificialmente pela simulação de fragmentação da população da Reserva em 3 categorias: Fr-25\%: permanência de 25\% das árvores no local (4 repetições: Sp-1, Sp-2 Sp-3 e Sp-4); Fr-50\%, permanência de 50\% de árvores no local (2 repetições: Sp-5 e Sp-6); Cs $\geq \mathbf{6 0}$ (Sp-7), corte seletivo das árvores com DAP igual ou superior a $60 \mathrm{~cm}$ e PO, permanência de todas as árvores da população original situada na Reserva. Os valores entre parentes são os desvios padrões........................................................53

Tabela 9. Freqüências alélicas, número de alelos perdidos e número de alelos fixados de subpopulações criadas artificialmente e agrupadas em 3 categorias: Fr-25\%: permanência de 25\% das árvores no local (4 repetições: Sp-1, Sp-2 Sp-3 e Sp-4); Fr-50\%, permanência de 50\% de árvores no local (2 repetições: Sp-5 e Sp-6); Cs $\geq \mathbf{6 0}$ (Sp-7), corte seletivo das árvores com DAP igual ou superior a $60 \mathrm{~cm}$ e PO, permanência de todas as árvores da população original situada na Reserva. 55

Tabela 10. Estatísticas $F$ de Wright para cada loco e a média de uma população natrual de C. speciosa, referente as categorias de fragmentação Fr-25\% e Fr-50\%, onde $F_{\text {is }}$ é o coeficiente de endogamia médio dentro de cada subpopulação, $F_{s t}$ é a divergência genética entre populações e $F_{i t}$ é o coeficiente de endogamia total para espécie: 57

Tabela 11. Estimativas das freqüências alélicas e índices de diversidade genética de 4 populações naturais de $C$. speciosa procedentes de fragmentos florestais situados na região de Bauru/SP, obtidos através da análise de 8 locos alozímicos. Os valores entre parênteses são os desvios padrões. 60

Tabela 12. Probabilidades relativas ao teste exato de Fisher (Valores de P) para verificar os desvios do equilíbrio de Hardy-Weinberg, em 4 populações naturais de $C$. speciosa procedentes de fragmentos florestais na região de Bauru/SP, obtidos através da análise de 6 locos alozímicos 64 
Tabela 13. Estatísticas F de Wright para cada loco e a média dos locos, referentes a 4 populações naturais de C.speciosa, procedentes de fragmentos florestais na região de Bauru/SP, obtidos pela análise de 6 locos alozímicos: ........65

Tabela 14. Distância genética de Nei (1972) em porcentagem, referentes a 4 populações naturais de C.speciosa, procedentes de fragmentos florestais na região de Bauru/SP, obtidas pela análise de 6 locos alozímicos: ........67 


\title{
ESTRUTURA GENÉTICA DE POPULAÇÕES NATURAIS \\ DE Chorisia speciosa St. Hil. (BOMBACACEAE) EM \\ FRAGMENTOS FLORESTAIS NA REGIÃO \\ DE BAURU (SP) - BRASIL
}

\author{
Autora: LINA MARIA FARINA INGLEZ DE SOUZA \\ Orientador: Prof. Dr. PAULO YOSHIO KAGEYAMA
}

\section{RESUMO}

Para investigar os efeitos da fragmentação florestal na variação genética de Chorisia speciosa St. Hil (Bombacaceae) foram comparados os parâmetros genéticos de 4 populações naturais, sendo uma representando um fragmento grande e não perturbado e três representando fragmentos florestais pequenos e perturbados. Os. dados foram provenientes de locos alozímicos. A área selecionada como fragmento grande e não perturbado foi a Reserva Estadual de Bauru (Reserva), onde foram amostradas 53 árvores e 30 progênies. Os fragmentos pequenos e perturbados situam-se a um raio de 30 km da Reserva, onde foram amostradas, 15 árvores (Fazenda Santa Terezinha), 12 árvores (Fazenda Laranja Azeda) e 10 árvores (Fazenda Shangrilá). Na população situada na Reserva, além das estimativas dos parâmetros genéticos, foram feitas análise de autocorrelação espacial, estimativa da taxa de cruzamento e a simulação de efeitos de fundadores potenciais, obtidos pela subdivisão artificial desta população em diferentes tamanhos (categorias de fragmentação). A espécie apresentou altos valores relativos aos índices de diversidade (heterozigosidade média observada, heterozigosidade média esperada, polimorfimo e número médio de alelos por loco) em todos os fragmentos. Não houve perda significativa de heterozigosidades da população fonte (todas as árvores analisadas conjuntamente) para as populações fragmentadas. Conforme as predições 
teóricas, a deriva genética ficou evidenciada pela perda, fixação e oscilação aleatória de alelos e também pela alta divergência interpopulacional $\left(F_{s t}=0,183\right)$ A da taxa de cruzamento multiloco $\left(t_{m}\right)$ estimada para um evento reprodutivo ocorrido em 1991 foi 0,881, sugerindo níveis de endogamia para a espécie proveniente de autofecundação e cruzamento entre índivíduos aparentados. Esta estimativa corrobora com o coeficiente de endogamia obtido para as progênies que teve um valor significativo e positivo $(F=0,239)$. Os gargalos artificiais criados na população da Reserva, mostraram que a perda genética se refletiu nas distribuições alélicas, através das perdas e oscilações de freqüências de alelos raros e não se refletiu nas heterozigosidades. Esta análise corroborou com a autocorrelação espacial que mostrou ausência de estruturação nesta população. 


\title{
GENETIC STRUCTURE OF NATURAL POPULATION GENETIC OF Chorisia speciosa St. Hil. (BOMBACACEAE) IN FOREST FRAGMENTS IN BAURU (SP) - BRAZIL
}

\author{
Author: LINA MARIA FARINA INGLEZ DE SOUZA \\ Adviser: Prof. Dr. PAULO YOSHIO KAGEYAMA
}

\section{SUMMARY}

In order to investigate the effects of forest fragmentation on the genetic variation of Chorisia speciosa, the genetic parameter estimates of four natural population were compared. These populations comprise a non-disturbed large fragment (284 hectares) and three disturbed and small forest fragments (30 hectares). Through isoenzyme electrophoresis, the genotypes were obtained from enzimatic patterns of 6 enzymes ( 8 or 9 locos) extracted from leaf tissue. The large fragment is the "Estação Ecológica de Bauru" (Reserve), where 53 trees and 30 progeny arrays were sampled. The small and disturbed fragments are located in a radius of $30 \mathrm{Km}$ from large one (Reserve), where populations of 15 trees (Farm "Santa Terezinha"), 12 trees (Farm "Laranja Azeda") and 10 trees (Farm "Shangrila") were sampled in each one. In the Reserve population besides the genetic parameter estimates, spatial autocorrelation analysis and the mating system through multilocus outcrossing rate were made. The founder effect were simulated through artificial subdivision of the Reserve population in different categories of fragmentation. The species presented relatively high values of genetic diversity when compared to other species tropical trees. There were not significant heterozigosity losses between the source population (all population grouped) and the fragments. In accordance with the theoretical predictions, the genetic drift was evident by loss, fixation and oscillation of alleles and also by high interpopulation divergence $\left(F_{s t}=0.183\right)$. The estimated multilocus outcrossing rate $\left(t_{m}\right)$ for one reproductive event (1991) was 0.881 . 
This value suggests levels of inbreeding for Chorisia speciosa originated from selffertilization and mating between relatives. This amount of inbreeding is corroborated by the inbreeding coefficient of progeny arrays $(F=0.239)$, which had a significant and positive value. The artificial founder effect created in the Reserve population showed that the genetic losses were reflected in the allelic distributions through losses and oscilation of rare allele frequences and not in heterozigosite values. 


\section{ESTRUTURA GENÉTICA DE POPULAÇÕES NATURAIS DE Chorisia speciosa St. Hil. (BOMBACACEAE) EM FRAGMENTOS FLORESTAIS NA REGIÃO DE BAURU (SP) - BRASIL}

\section{INTRODUÇÃO}

A destruição de habitats e conseqüente fragmentação de populações naturais, tem levado muitas espécies a atingirem uma limitação evolutiva, decorrente da perda de variabilidade genética, que basicamente reduz a habilidade das populações de se adaptarem a mudanças ambientais (Barret \& Kohn, 1991).

Ellstrand \& Ellan (1993) esclarecem que a fragmentação florestal ocasiona o isolamento populacional, os efeitos de borda, a colonização de espécies exóticas, a diminuição do fluxo gênico e a reprodução entre indivíduos aparentados ou entre menor número de indivíduos. As duas principais causas da diminuição do tamanho populacional são a deriva genética e a endogamia. A primeira provoca perda de variação genética e a segunda é responsável pela perda da heterozigosidade.

No Brasil, estudos de fragmentação florestal têm sido desenvolvidos pelo Projeto Dinâmica Biológica de Fragmentos Florestais (PDBFF). Este trabalho existe há 16 anos na região amazônica, próximo à cidade de Manaus e contempla diversos tipos de pesquisas referentes aos efeitos da fragmentação de habitats, por exemplo: a interrelação entre animais, as alterações microclimáticas, a demografia de plantas, a dinâmica de populações de animais, a relação com a biodiversidade e outros (Schierholz, 1991). Recentemente foi desenvolvida uma pesquisa sobre a estrutura genética de duas espécies de Lecythdaceae nestes fragmentos (Lepsch-Cunha,1996).

Outra linha de pesquisa que vem sendo desenvolvida é apontada por Viana (1995), e envolve a sucessão florestal e a biodiversidade de fragmentos. Fatores tais como o histórico de perturbação de fragmentos, seu tamanho e sua forma, seu nível de isolamento, natureza de sua vizinhança e do ecossistema são apontados como aspectos 
que influenciam a estrutura da comunidade de plantas. $\mathrm{O}$ autor enfatiza a necessidade de se considerar os fragmentos florestais pequenos como remanescentes de uma rica e ameaçada biodiversidade e, portanto, merecedores de uma abordagem séria, priorizando o manejo e conservação destas unidades.

A literatura que aborda estimativa de parâmetros genéticos advindos de populações nativas de espécies arbóreas tropicais ainda é escassa, sendo que os estudos normalmente tratam aspectos ecológicos e demográficos de populações.

O laboratório de reprodução e genética de espécies arbóreas tropicais (LARGEA- ESALQ/USP) vem trabalhando com estudos de variação genética, visando dar subsídios à conservação genética e ao manejo de populações naturais, priorizando espécies raras ou que ocorrem em baixa densidade na mata.

No Brasil, um ecossistema que representa este modelo de paisagem fragmentada é a floresta mesófila semidecídua, também conhecida como floresta do planalto. Ocupa os Estados de São Paulo, Paraná, Mato Grosso, Mato Grosso do Sul e Goiás e é abrigo de uma rica diversidade de espécies, distinta em sua estrutura e composição das Florestas Amazônica e Atlântica (strictu-sensu) (Leitão- Filho, 1987). Este ecossistema é um bom alvo para estudos, visando a conservação.

As espécies raras, que conforme Hubbell \& Foster (1986), possuem densidade igual ou menor que 1 indivíduo por hectare, podem ser apontadas como referência, para estudos genéticos visando a conservação. Por exigirem grandes áreas para manutenção de suas populações, um plano de conservação centrado nestas, contemplará a conservação de muitos outros grupos. Outro aspecto a ser considerado é que estas espécies são as maiores representantes da diversidade em floresta tropical e que apesar disso, existem poucos estudos ecológicos e genéticos pertinentes, sobretudo porque são dificilmente capturadas em amostragens normais (Kageyama \& Gandara, 1994).

A raridade em floresta tropical tem sido amplamente debatida, por diversos autores. Lepsch-Cunha (1996) cita e discute diversos trabalhos que abordam a raridade, 
desde a sua definição até o entendimento das comunidades e a sua importância para a coexistência de um elevado número de indivíduos de diferentes espécies no mesmo local.

Uma categorização clássica de raridade foi apontada por Bawa \& Ashton (1991), distinguindo quatro grupos em floresta tropical; seguintes:

1. Espécies uniformemente raras, ou seja tipicamente ocorrem em populações de baixa densidade (menos de 1 indivíduo por ha);

2. Espécies comuns em um local e raras entre os locais, onde as áreas de maiores concentrações representam fontes de propágulos, e as áreas de menores densidades estão sujeitas a grandes flutuações;

3. Espécies endêmicas, sendo que o tamanho populacional pode ser grande ou pequeno;

4. Espécies agrupadas, mas em que a densidade populacional total é baixa. Neste caso os agrupamentos podem estar associados à biologia da espécie e também aos requisitos físicos locais.

Em linhas gerais, o presente trabalho consiste no estudo da diversidade genética de populações naturais de $C$. speciosa em fragmentos florestais de diferentes tamanhos e estados de conservação. Trata-se de uma espécie de baixa densidade, típica das florestas de planalto, de uso paisagístico, com dispersão de sementes pelo vento e polinização por animais, que por não apresentar valor econômico possui populações representadas mesmo em pequenos fragmentos. 


\section{OBJETIVOS}

Os objetivos dividem-se em duas partes:

a.) Quantificar a variação genética, determinar a taxa de cruzamento, inferir sobre o equilíbrio genético e verificar a estrutura familiar de uma população natural de C. speciosa situada em um fragmento grande e não perturbado.

b.) Verificar as consequiências genéticas da fragmentação de populações naturais de $C$. speciosa, através de 2 abordagens:

b.1.) Verificando as possíveis alterações dos parâmetros genéticos que ocorreriam, caso uma população grande e não perturbada fosse fragmentada, simulandose nesta população efeitos fundadores potenciais;

b.2.) Verificando as possíveis alterações dos parâmetros genéticos que ocorreram, em quatro populações, situadas em fragmentos de distintos tamanhos e graus de perturbação. 


\section{HIPÓTESES}

As hipóteses testadas são:

a.) As espécies raras, tais como a paineira, apresentam altas taxas de diversidade genética.

Predição: para manutenção da diversidade genética de suas populações, a espécie deve apresentar altas taxas de cruzamento e ausência de estrutura familiar no fragmento grande e não perturbado.

b.) A fragmentação florestal afeta a estrutura genética de populações naturais de C. speciosa em poucas gerações.

Predição: esta alteração provoca a perda da variabilidade genética que se reflete nos diferentes parâmetros genéticos. 


\section{REVISÃO BIBLIOGRÁFICA}

\subsection{A Espécie: Chorisia speciosa St Hil.}

Chorisia speciosa St. Hil. é uma espécie arbórea caducifolia, de grande porte, pertencente à família Bombacaceae. As folhas são alternas e digitadas, com 4 a 7 folíolos, flores hermafroditas grandes, de coloração rósea, dispostas em racemos axilares e terminais. O fruto é uma cápsula oblonga, deiscente, de coloração parda quando maduro. As sementes são oleaginosas, leves, de coloração preta, envoltas por pêlos branco-amarelados (paina), que auxiliam a dispersão pelo vento. Cada fruto possui em média de 120 a 200 sementes e produz cerca de $12 \mathrm{~g}$ de paina. A produção média por árvore é de 300 a 700 frutos (Pio Corrêa \& Penna, 1978; Carvalho, 1994; Lorenzi, 1992).

É conhecida por diversas sinonímias no Brasil: paineira, árvore-de-lã, barriga d'água, paina-de-seda, paineira-branca, paineira-rosa, paineira-de-seda. $\mathrm{Na}$ Argentina é conhecida por “ palo botilla” e no Paraguai, "samu'u” (Carvalho,1994).

No Estado de São Paulo, o florescimento se dá nos meses de dezembro a maio e a presença de frutos é detectada a partir de julho, estendendo-se a dispersão de sementes até meados de setembro. Em plantio, as primeiras flores e frutos aparecem entre 5 e 8 anos de idade (Carvalho,1994 e Salgado \& Ciaramello,1990).

Borges et al. (1986), em um estudo de biologia reprodutiva observaram que a autopolinização não produziu frutos; a polinização aberta produziu $3 \%$ dos frutos e a polinização cruzada manual produziu cerca de $85 \%$ dos frutos. Gibbs \& Bianchi (1992) estudaram o evento de pós-polinização de muitas árvores cultivadas na Estação Experimental Central do Instituto Agronômico e observaram que ocorre a formação de tubo polínico e penetração do óvulo, tanto para flores auto-polinizadas quanto para aquelas de polinização cruzada, porém $100 \%$ das flores auto-polinizadas são abortadas posteriormente. Este fenômeno é conhecido por auto-incompatibilidade tardia, e já foi detectado em algumas espécies arbóreas, tais como: Melaleuca capitata e Theobroma cacao. 
As flores apresentam características comuns à Síndrome de Ornitofilia, descritas por Faegri \& Pijl (1976). Morellato (1991) afirma que os prováveis polinizadores seriam morcegos ou beija-flores; já Castillo (1986) cita como possíveis polinizadores borboletas e mariposas. Entretanto não existe trabalho específico sobre a polinização e a literatura apenas confirma que se trata de uma espécie, tendendo à polinização cruzada feita por animais (Carvalho,1994).

Castillo (1986) observou que as sementes da espécie são dispersas pelo vento (anemocoria) a distâncias superiores a $160 \mathrm{~m}$ e que a maior densidade de sementes é observada nas vizinhanças da matriz.

Existem indícios de que a germinação de sementes situadas próximas às matrizes seja dificultada pela ocorrência de predação por um percevejo do gênero Dysdercus. Tal fato já foi observado em campo, na Estação Ecológica de Ibicatu (Elza Guimarães, comunicação pessoal), em muitos indivíduos situados no Parque da ESALQ e na Mata do Engenho Central, todas áreas situadas no município de Piracicaba (informação pessoal). Um inseto do mesmo gênero foi observado predando sementes de Ceiba pentandra, em uma população natural situada na Ilha de Barro Colorado (Murawski \& Hamrick,1992). Esta é uma espécie de Bombacaceae, cujas características botânicas assemelha-se à $C$. speciosa.

Em relação ao grupo ecológico quanto à sucessão secundária, a espécie é considerada secundária tardia, segundo a classificação de Budowski (1965), se regenerando a partir do banco de plântulas em clareiras pequenas. Carvalho (1994) afirma que a paineira é uma espécie de crescimento rápido a moderado, estabelece-se a pleno sol e tolera sombreamento no estádio de plântula.

Joly \& Craford (1982) constataram que a paineira apresenta mecanismos fisiológicos específicos que a tornam tolerante ao encharcamento, aparecendo com freqüência em zonas ripárias.

Sua área de ocorrência é ampla e abrange principalmente as Florestas Mesófilas Semidecíduas nos Estados de São Paulo, Minas Gerais, Goiás, Mato Grosso do Sul, Paraná, Santa Catarina e Rio Grande do Sul. Fora do Brasil, ocorre na Argentina 
(nordeste) e Paraguai (centro e leste). Além disso, é cultivada em regiões tropicais e subtropicais do hemisfério norte, até as Antilhas (Lorenzi,1992 e Carvalho,1994).

No passado, a paineira foi alvo de interesse comercial, sendo indicado o uso de sua madeira para caixotaria em geral e pasta celulósica. A paina, caracterizada como uma fibra leve e elástica, foi eleita como o principal produto econômico da espécie. Por apresentar propriedades anti-alégicas, ser isolante contra ruídos, não absorver umidade e não apodrecer em contato com água do mar foi indicada para os mais variados empregos em estofagem e revestimento, tais como: colchões, travesseiros e salva-vidas. Na década de 30 , chegou a ter boas cotações no mercado, sendo utilizada, tanto internamente quanto exportada para Europa (Wahnschaffe, 1931, Ramalho, 1972 e Carvalho, 1994).

Ramalho (1972) ressaltou também a importância comercial das sementes que, por concentrar maiores teores de óleo que as sementes do algodão (15 a 20\%), seriam potencialmente úteis para fabricação de óleo industrial ou para alimentação.

Entretanto, seu uso comercial não se efetivou e atualmente a paineira tem apenas valor ornamental. Apresenta também grande importância ecológica, sendo atrativa para fauna. Suas sementes e folhas são consumidas por pássaros, macacos e pequenos mamíferos como a cotia e o veado (Sr. Adolpho Dario, comunicação pessoal) e, portanto, pode ser útil em plantios de recuperação de áreas degradadas.

Por ser uma espécie de baixo valor econômico, foi pouco estudada quanto à tecnologia de produção de mudas e plantações. Mas, tal fato possibilitou que suas populações se conservassem mesmo em fragmentos pequenos e perturbados, o que favorece os estudos nestes remanescentes.

Diversos levantamentos fitossociológicos em florestas mesófilas semidecíduas confirmam sua ocorrência, como mostra a Tabela 1: 
Tabela 1: Ocorrência de Chorisia speciosa em florestas mesófilas semidecíduas do interior do Estado de São Paulo, baseado em levantamentos fitossociológicos.

\begin{tabular}{lccc}
\hline \multicolumn{1}{c}{ Local } & $\begin{array}{c}\text { Área da } \\
\text { Mata (ha) }\end{array}$ & $\begin{array}{c}\mathbf{N}^{\mathbf{0}} \text { de Ind.na } \\
\text { amostra (1ha) }\end{array}$ & Fonte \\
\hline $\begin{array}{l}\text { Fazenda São Luis- } \\
\text { Tarumã/SP }\end{array}$ & 60 & 01 & Durigan,1994 \\
\hline $\begin{array}{l}\text { Mata Ciliar do Rio } \\
\text { Jacaré Pepira-Brotas/SP }\end{array}$ & 40 & 04 & Salis, 1990 \\
\hline $\begin{array}{l}\text { Fazenda São José-Rio } \\
\text { Claro/SP }\end{array}$ & 580 & 07 & Pagano,1985 \\
\hline $\begin{array}{l}\text { Mata Ciliar do Rio } \\
\text { Passa Cinco/SP }\end{array}$ & 278 & 01 & Rodrigues, 1991 \\
\hline $\begin{array}{l}\text { Mata da Pedreira- } \\
\text { Piracicaba/SP }\end{array}$ & - & 02 & Catarino,1989 \\
\hline $\begin{array}{l}\text { Reserva Estadual de } \\
\text { Bauru/SP }\end{array}$ & 287 & 20 & Cavassan,1982 \\
\hline
\end{tabular}

Cavassan (1982) observou que C. speciosa apresentou os maiores diâmetros, o que lhe confere o maior valor de dominância relativa e dominância por área dentre todos indivíduos amostrados na Estação Ecológica de Bauru. Cavassan (1982) e Pagano (1985) consideram-na uma espécie comum, devido aos resultados dos levantamentos fitossociológicos nos dois locais estudados pelos autores. Entretanto a pequena área amostrada nestes estudos (menos de 1 ha) não é suficiente para se inferir a real densidade da espécie localmente.

Em 1991, na Estação Ecológica de Bauru (287 ha), foi feito um levantamento expedito, que consistiu na contagem do número de árvores florescendo. Foram identificados 92 indivíduos de C. speciosa (Sr. Adolpho Dario, comunicação pessoal). Neste caso, a densidade estimada para esta população seria de 1 indivíduo a cada 2 ha, podendo ser enquadrada como uma espécie de baixa densidade. 


\subsection{Estudos de Variaçāo Genética em Populações Naturais}

Nos últimos anos, a proteção da diversidade genética de espécies, tornou-se prioridade inerente aos planos da conservação, sendo o objetivo a longo prazo manter a viabilidade evolutivas destas. A variação genética fornece a matéria-prima para as mudanças evolutivas, influindo nas performances fisiológica e demográfica das populações (Weir, 1990; Huenneke, 1991). A genética de populações tornou-se um campo de grande interesse, pois tem por fim descrever a variação genética em populações e estudar os mecanismos de manutenção dessa variação (Nei, 1987)

A organização dos níveis de variação genética entre e dentro de populações é referenciada como estrutura genética e é decorrente de fatores tais como: sistema reprodutivo, níveis de endogamia, seleção natural, fluxo gênico e deriva genética. Tais fatores podem explicar o comportamento de alelos nas populações (vários autores cit. por Reis, 1996).

As medidas mais simples de variação são as contagens de genótipos; a partir destes obtém-se outros parâmetros de simples estimativa, como número de alelos por loco (A) e as freqüências alélicas. Para analisar a variação interpopulacional são necessárias funções mais complexas de freqüências, tal como a diversidade gênica (Weir,1990).

Weir (1990) esclarece que a análise de dados genéticos deve ser baseada em algum modelo ou teoria. O modelo clássico que embasa a genética de populações é chamado de Teorema de Hardy-Weinberg (EHW), que presume que uma população de tamanho infinito, onde os indivíduos se cruzam aleatoreamente e que não sofre ação de forças perturbadoras (mutação, seleção, migração) estabelece frequiências genotípicas binomiais que não irão se alterar nas gerações subseqüentes. Os desvios das proporções esperadas pelo EHW significam que uma ou mais das pressuposições do modelo foi violada (Futuyma, 1992). 
A partir deste modelo é possível estimar a diversidade gênica, que é definida como um menos a soma das frequiências alélicas ao quadrado e é esperada ser a mesma que a freqüência de heterozigotos segundo o EHW.

A possibilidade de contar o número de locos com variação, verificar número de alelos, distinguir homozigotos de heterozigotos tornou-se efetiva com a codificação dos locos de proteínas, especialmente as enzimas. A técnica mais comum para distinguir diferentes formas genéticas (alozimas) de uma enzima é a eletroforese em gel (Futuyma,1992). Esta técnica consiste na colocação de extratos de tecidos de diversos indivíduos num gel poroso, através do qual é aplicado um potencial elétrico. A diferenciação na composição de aminoácidos e nas cargas elétricas conferem às enzimas movimentação, de modo que tendem a se separar no gel. Suas posições exatas no gel são encontradas através de sistemas específicos de coloração, formando certos padrões (zimogramas) passíveis de interpretação (Alfenas et al,1991 e Futuyma, 1992).

Hamrick \& Godt (1990), com base na literatura de 653 estudos de aloenzimas, observaram os dados genéticos de 449 taxas, que envolviam plantas herbáceas, arbóreas e arbustivas, visando relacionar os níveis de diversidade com a ecologia das espécies. Em média, as plantas apresentaram $50 \%$ dos locos polimórficos, uma heterosigozidade média esperada de 0,149 e o número de alelos por loco variou de 1,5 a 3,0. Verificaram que para as espécies arbóreas tropicais, a maior parte da diversidade genética encontra-se dentro de populações e que os dados revelam variações expressivas nos níveis de diversidade genética, na porcentagem de locos polimórficos e no número de alelos/loco. Concluíram que o sistema reprodutivo e a distribuição geográfica foram os fatores que mais contribuíram para a variação dos dados.

Hamrick et al (1993) consideraram que espécies com baixa densidade de indivíduos adultos teriam maior heterogeneidade genética espacial devido à dispersão de sementes, se comparadas com as espécies de alta densidade. Este fato é mais freqüente em espécies com dispersão de sementes restrita, onde as plântulas têm probabilidade maior de serem recrutadas nas proximidades de suas matrizes. 
Gandara (1996) destaca a importância do conhecimento da estrutura genética espacial para o estabelecimento de estratégias de amostragem de populações naturais, tanto para a conservação genética quanto para fins de melhoramento, possibilitando a formação de amostras significativas.

Para o estudo de locos alozímicos pressupõe-se que os mesmos sejam representativos do genoma e que são neutros, porque não estão diretamente sujeitos às forças seletivas. Reis (1996) apresenta uma revisão detalhada sobre o assunto.

\subsection{Fragmentação Florestal e suas Conseqüiências Genéticas}

No período de 100 a 200 anos a fragmentação de habitats, resultado de ações antrópicas, tem afetado muitos ecossistemas, por exemplo as florestas. O desmatamento de grandes áreas florestais para ocupações agrícolas, acarretou um outro modelo de paisagem composta de pequenas ilhas de floresta com certo grau de isolamento e formadas por pequenas populações (Young et al, 1993, Ballal et al 1994).

As predições iniciais sobre as consequiências genéticas da fragmentação de habitats enfocam o tamanho populacional reduzido e o isolamento populacional. Os estudos mais recentes discutem sobretudo aspectos da variação genética, níveis de endogamia, fluxo gênico e divergência interpopulacional (Young et al, 1996).

As alterações decorrentes da fragmentação contribuem para a erosão da variação genética e aumento da divergência genética entre populações, através dos seguintes eventos: i) aumento da deriva genética; ii) aumento da endogamia; iii) redução do fluxo gênico e iv) aumento da probabilidade de extinção local. Tais efeitos, apresentam implicações em relação a persistência da espécie. No curto prazo, a perda da heterozigosidade pode reduzir a aptidão individual da espécie, inviabilizando o remanescente populacional. No longo prazo, a redução da riqueza alélica deve limitar a habilidade das espécies a responderem as mudanças devidas a 
ação de forças seletivas (Young et al, 1996; Ellstrand \& Ellan, 1993, Charlesworth \& Charlesworth, 1987).

Em síntese, a fragmentação de habitats pode causar perda de variação genética por duas vias. Primeiro, a redução do tamanho populacional cria gargalos genéticos ("bottlenecks"), porque os indivíduos que ficam contêm apenas uma pequena amostra do "pool" gênico original. Em segundo lugar, como conseqüência, a pequena população remanescente, caso permaneça isolada por muitas gerações, terá contínua perda de alelos devido à deriva genética aleatórea.

Quando as populações são pequenas e isoladas umas das outras, a deriva genética terá influência dominante na estrutura genética. Se as populações tornam-se pequenas por longo tempo, os efeitos da amostragem são acumulativos. Em grandes populações tem-se pouco efeito de deriva. Em populações pequenas (menos de 100 indivíduos) as freqüências gênicas podem sofrer grandes flutuações em diferentes gerações, ocasionando a perda de alelos (Barret \& Kohn, 1991; Ellstrand \& Ellan,1993; Young et al, 1993).

Dada uma estrutura de população estável e assumindo um modelo de fluxo gênico de ilhas, a divergência genética interpopulacional aumentará devido à deriva, particularmente quando o tamanho populacional $\left(\mathrm{N}_{\mathrm{e}}\right)$ e o fluxo gênico são $\mathrm{N}_{\mathrm{e}} . \mathrm{m}<1$ (onde $m$ é a fração de migrantes por geração). Em contraste, apenas uma pequena quantidade de fluxo gênico (aproximadamente 1 indivíduo por geração) é requerida para reduzir a perda de alelos (Templeton, 1990; Young et al, 1996)).

Ellstrand \& Ellan (1993) reforçam que o fluxo gênico é considerado benéfico por previnir a depressão endogâmica e a depleção da variação genética em pequenas populações. Para a maioria das espécies perenes, o aumento de fluxo gênico em apenas duas décadas é suficiente para anular o efeito da deriva e da endogamia. A transferência de poucos genótipos de sucesso de uma geração para outra pode ser suficiente para manter o fluxo gênico na magnitude de ordem histórica e natural. 
A deriva genética muda a distribuição da variação genética de duas formas: i) diminui a variação dentro de populações refletida pela perda de heterozigosidade e de alelos e ii) aumenta a diferenciação entre populações. A diminuição da heterozigosidade pode estar refletida diretamente na redução de genes nos remanescentes pequenos ou pela erosão da heterozigosidade quando a endogamia acompanha a fragmentação (Barret \& Kohn,1991; Ellstrand \& Ellan,1993, Ballal et al, 1994)

Dados provenientes de estudos com aloenzimas sugerem que uma redução do tamanho populacional e isolamento das populações causam redução da variação genética (Billington, 1991; Pollans \& Allard, 1989; Saunders et al, 1991; Wilcove, 1987). Este efeito foi observado em estudos com as espécies herbáceas Salvia pratensis, Scabiosa columbaria e Gentiana pneumonanthe e a arbórea Eucalyptus albens. Os dados destas espécies sugerem que a perda genética verificada deve-se mais ao efeito de gargalo genético do que à deriva genética (Young et al, 1996) .

As predições teóricas indicam que as consequiências da deriva genética dependem do número de gerações que ocorreram nos remanescentes desde a fragmentação. Por exemplo, as espécies de ciclo de vida curto, tais como as herbáceas, mostram rapidamente grande perda de variação oriunda da deriva. Quando se têm poucas gerações, caso das espécies de ciclo de vida longo (arbóreas), os resultados observados devem-se ao efeito de gargalo genético (Young et al, 1996).

A endogamia é o cruzamento entre indivíduos aparentados e tem como conseqüência genética a homozigose dentro de populações. Em plantas, a endogamia ocorre por autofecundação e/ou aumento de cruzamentos entre indivíduos aparentados. A autofecundação é o extremo da endogamia e é evitada em plantas por mecanismos de auto-incompatibilidade ou por dioicia. A endogamia biparental é mais freqüente quando populações são pequenas ou quando exibem estrutura 
genética espacial. Esta estrutura é desenvolvida quando a dispersão de pólen e sementes é restrita (Ellstrand \& Ellan, 1993).

A perda de vigor decorrente da endogamia é conhecida como depressão endogâmica. A endogamia acarreta uma diminuição dos níveis de variação genética resultando numa baixa taxa de recrutamento e potencial risco de extinção (Hamrick \& Loveless, 1986).

A redução drástica do número de indivíduos de uma espécie em um certo local num determinado tempo é designado de gargalo ("Bottlenecks") . O gargalo contribui para a perda de alelos, especialmente os raros, e isto é muito mais efetivo do que a perda de heterozigosidade (Barret \& Kohn,1991).

Os autores citados, com base no trabalho de Nei (1975), salientam que a quantidade da redução da heterozigosidade média por loco não depende apenas do tamanho do gargalo, mas também da taxa de cruzamento e crescimento da população. Caso esta cresça rapidamente a redução da heterozigosidade é mínima, mesmo que o número de fundadores seja pequeno. Em contraste, a perda do número médio de alelos por loco é profundamente afetado pelo tamanho do gargalo. Em geral a perda de alelos excede muito a perda da heterozigosidade média, embora com o tempo a perda de variação pode se tornar significativa.

Muitas espécies arbóreas possuem meios efetivos de dispersão de genes e com isso mantêm altos níveis de variação genética dentro de populações com pouca diferenciação genética entre populações (Hamrick et al, 1979; Hamrick, 1982; Loveless \& Hamrick, 1987; Hamrick \& Godt, 1990).

Entretanto, diversidade genética e estrutura podem ser alteradas se a fragmentação florestal modificar os padrões de dispersão de pólen e sementes (Foré $e t$ al, 1992).

A fragmentação de habitats também pode colaborar para modificações no sistema de cruzamento, alterando a composição dos agentes polinizadores ou mesmo em seus comportamentos individuais. Sendo assim, estas mudanças também podem se refletir nos parâmetros relativos ao sistema de cruzamento. 


\section{MATERIAL E MÉTODOS}

\subsection{Caracterização dos Locais de Estudo}

Foram localizadas quatro áreas de estudo e levantadas 4 populações naturais de $C$. speciosa, um fragmento grande e não perturbado, que será considerado neste trabalho como área primária ou de referência e três fragmentos pequenos e perturbados situados em um raio de $30 \mathrm{~km}$ da área de referência.

Como área de referência foi eleita a Estação Ecológica de Bauru-RE-7 (Reserva), pertencente ao Instituto Florestal, que se localiza ao norte do município de Bauru, dista três $\mathrm{km}$ da rodovia Bauru-Iacanga (SP 321) na altura do $\mathrm{km} \mathrm{352,} \mathrm{nas}$ seguintes coordenadas: $22^{\circ} 19^{\prime} \mathrm{S}$ e $49^{\circ} 04^{\prime} \mathrm{W}$ e possui uma área de 287,28 ha. A vegetação é caracterizada como Floresta Mesófila Semidecídua (Cavassan, 1982) e encontra-se atualmente cercada por pastagens.

O critério para seleção de tal área, se deve ao fato de ser uma unidade de conservação, protegida pelo Estado e que a mais de 30 anos não sofre qualquer modalidade de alteração (fogo, caça ou extração). Quando adquirida pelo Estado, em 1961, havia trechos desprovidos de vegetação que foram recuperados mediante a introdução de espécies pioneiras e controle de capim. Detalhes das medidas de recuperação estão descritas em Nogueira (1990). Atualmente a fisionomia destes trechos se equipara às áreas não desmatadas, onde encontra-se a população levantada neste trabalho.

Anteriormente ao ano de 1961, esta mata pertencia a uma fazenda de café e não se sabe qual exploração ocorria. Em relação a outras maneiras de perturbação, se têm relatos de que em 1942 houve fogo no local, fato que pode ser evidenciado também pela presença de carvão em pontos isolados (Cavassan, 1982).

Para selecionar os fragmentos pequenos e perturbados foram utilizados os seguintes critérios: i) que a área tivesse evidências de perturbação (caça, fogo e/ou extração), ii) que a área fosse representativamente menor que a Reserva (pelo menos $1 / 3$ 
de seu tamanho), iii) que o fragmento fosse situado na região da Reserva (num raio de no máximo $30 \mathrm{~km}$ ) e iv) que houvesse ocorrência de pelo menos 10 indivíduos de $C$. speciosa no fragmento. A partir destes critérios, 3 fragmentos foram selecionados, a saber:

1. Fazenda Santa Terezinha (Santa), situa-se no Bairro Areia Branca, município de Piratininga, possui 25 ha e dista $27 \mathrm{~km}$ da Reserva. Tem mais de 50 anos de fragmentação. Há 5 anos atrás pegou fogo, mas apresenta sinais de recuperação (indivíduos de porte grande e espécies em regeneração), porém a incidência de cipós ainda é alta, sobretudo na borda da mata. No entorno encontram-se pastagens e num raio de $3 \mathrm{~km}$ outros fragmentos do mesmo porte.

2. Fazenda Laranja Azeda (Laranja), localiza-se no bairro Brasília Paulista, município de Piratininga, possui 23 ha e encontra-se a $29 \mathrm{~km}$ da Reserva e a $2 \mathrm{~km}$ do fragmento Santa. Possui mais de 50 anos de fragmentação. Não há sinal de fogo e extração, mas ocorre invasão de gado. Em seu entorno predominam pastagens. Existem dois fragmentos pequenos (10 ha) em um raio de $200 \mathrm{~m}$.

3. Fazenda Shangrilá (Shangrilá), localiza-se no bairro Val-de-Palmas, no município de Bauru, sua área é de $50 \mathrm{ha}$. Dista $5 \mathrm{~km}$ da Reserva e $17 \mathrm{~km}$ dos fragmentos Santa e Laranja. Possui mais de 50 anos de fragmentação. Em seu entorno encontram-se cultivo de citros e abacaxi. Existe uma ferrovia que corta o fragmento. Em seu interior há evidências de extração recente de peroba e algumas áreas com evidência de fogo, além de alta invasão de cipós. Não está totalmente isolado, pois a $1500 \mathrm{~m}$ existe outro fragmento do mesmo porte.

As informações sobre o histórico dos fragmentos foram obtidas através de entrevista com a engenheiro agrônomo Ernani Bevenutti, que trabalha no DEPRN de Bauru/SP.

As quatro áreas descritas estão a uma altitude média de $570 \mathrm{~m}$. O clima, segundo a classificação de Koeppen é $C w a$, subtropical de monção com inverno moderado e seco e verão úmido. A precipitação pluviométrica média anual é 1281,08 $\mathrm{mm}(\mathrm{CV}=21,52 \%)$ e a temperatura média anual é de $21,37^{\circ} \mathrm{C}(\mathrm{CV}=10,81 \%)$ (Cavassan, 1982) 


\subsection{Levantamento das Populações, Coleta de Materiais e Produção de Mudas}

Esta etapa foi executada da seguinte maneira:

1. Em julho de 1991 foram colhidas sementes da população situada na Reserva, que se armazenaram em câmara fria $\left(5^{\circ} \mathrm{C}\right.$ - $40 \%$ UR) até 1994 , quando foram semeadas.

2. Em dezembro de 1994 foi feita a semeadura para obtenção de progênies relativas à população da Reserva. No período posterior a 15 dias procedeu-se à repicagem de 20 indivíduos por progênie, num total de 30 progênies. As mudas foram mantidas em sombrite $50 \%$ durante 2 semanas após a repicagem. A seguir foi iniciado um programa mensal de adubação, com fórmula de nitrogenado+micronutrientes, que foi intensificado (duas vezes por mês) no período em que se fizeram as análises laboratoriais.

3. Em julho de 1995 foram realizados o mapeamento e a coleta de ramos da população da Reserva. Os ramos foram utilizados para produção de mudas de matrizes através de enxertia. Estes foram tratados com solução de Benlate, embrulhados em jornal e acondicionados em saco plástico. A enxertia executou-se uma semana após as estacas terem sido coletadas, totalizando 10 enxertos para cada matriz. As mudas resultantes, mantidas em casa de vegetação, receberam quinzenalmente adubo nitrogenado+micronutrientes. O mapeamento valeu-se do auxílio de bússola e trena, obtendo-se as coordenadas das árvores, as distâncias entre elas e as respectivas circunferências a altura do peito (CAPs). A marcação foi feita com placas de alumínio e pregos galvanizados. Todos os indivíduos adultos encontrados na área foram coletados. As árvores estavam em fase de brotação e não apresentavam qualquer indício de frutos, mesmo no chão da mata não havia quaisquer sinais deles, indicando que neste ano a população não frutificou.

4. Em fevereiro de 1997 foram coletadas folhas e tomado o CAP de árvores adultas e jovens situadas nos 3 fragmentos: Santa, Laranja e Shangrilá. Os espécimes jovens apresentaram-se com porte semi-arbóreo (altura média 2,0 m), diâmetro inferior 
ao peito (DAP) inferior a $28 \mathrm{~cm}$ e não atingiam o dossel (provavelmente ainda não alcançaram idade reprodutiva) sendo assim representam indivíduos recrutados após a fragmentação. A amostragem adulta reuniu árvores de grande porte, atingindo o dossel (DAP > $38 \mathrm{~cm})$. Como a fragmentação se deu há mais de 50 anos, existe possibilidade de a população adulta também conter indivíduos originados após a fragmentação, pois a C. speciosa possui crescimento rápido. Em suma, a amostragem nestes fragmentos consistiu em conjunto de indivíduos que foram originados pré-fragmentação (adultos) e pós-fragmentação (jovens). $\mathrm{O}$ material foi acondicionado em sacos plásticos e transportado para o laboratório para análises eletroforéticas. Este material permaneceu uma semana em geladeira, período em que se procedeu as análises laboratoriais.

\subsection{Eletroforese de Isoenzimas}

\subsubsection{Testes preliminares}

O desenvolvimento do protocolo para eletroforese de isoenzimas envolveu uma série de testes no período de fevereiro a julho de 1995.

A primeira extração, feita com a solução 1 (Alfenas et al, 1990), apresentou problemas, pois o extrato das folhas viscoso prejudicava a embebição do papel de filtro (“wick"). Dando prosseguimento à corrida eletroforética, as bandas apareciam com rastro ou não apareciam. Segundo a literatura consultada (Soltis et al, 1983 e Kephart, 1990), o fato denotava degradação das enzimas devido à solução de extração inadequado. Assim foram testados várias soluções de extração propostos por: Alfenas et al (1991), Soltis et al (1983), Moraes (1992) e Paiva (1992). A solução empregada para a extração de enzimas de tecidos vegetais que apresentou melhor resultado foi baseada na solução 1 (Alfenas et al ,1990), modificada pela ausência de L-ácido ascórbico, bissulfito de sódio, borato de sódio e PEG-2000, conforme detalhado abaixo: 
1. Solução de extração para o volume de $100 \mathrm{ml}$, utilizado no protocolo de C.speciosa .

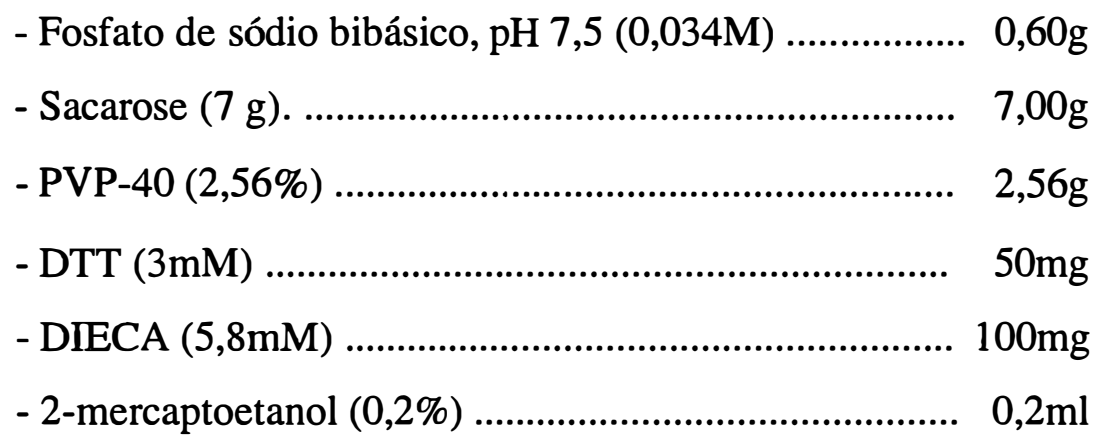

Definida a solução de extração, procederam-se testes rápidos, objetivando a melhoria dos padrões enzimáticos (zinogramas) e a determinação da metodologia exata para eletroforese de isoenzimas. Foram eles: modo de armazenamento, métodos de maceração, uso de centrifugação, tipo de folha e fase da planta (adulta ou jovem).

\subsubsection{Extração das isoenzimas}

As análises de eletroforese de isoenzimas foram realizadas a partir de tecidos foliares saudáveis, de mudas enxertadas (idade: 3 meses), mudas obtidas a partir de sementes (idade: 9 meses) e tecidos foliares de plantas adultas colhidos nos fragmentos. Os tecidos foliares eram preparados no dia anterior à corrida, ou seja eram lavados, secos e classificados, envolvidos em saco plástico e acondicionados na geladeira.

A extração consistiu na maceração das folhas com nitrogênio líquido e acréscimo de 5 a 7 gotas da solução de extração descrita anteriormente. 


\subsubsection{Preparo do tampão de gel e tampão de eletrodo}

Os tampões testados foram: citrato de morfolina, histidina e tris-citrato (Alfenas et al., 1991; soluções 7, 8,10 e 12). O melhor resultado foi obtido através do tampão:

Eletrodo: ácido cítrico 0,04M, titulado com N-(3 aminopropil) morfolina até $\mathrm{pH} 6,1$.

Gel: diluição de 1:20 do tampão de eletrodo.

O gel utilizado foi de penetrose de amido, com concentração de $13 \%$.

O mesmo sistema gel/eletrodo foi utilizado para os 6 sistemas isoenzimáticos estudados.

\subsubsection{Sistemas isoenzimáticos testados}

Foram testados os seguintes sistemas:

- Leucina Aminopeptidase (LAP - E.C. 3.4.11.1)

- Alfa-Esterase (ALFA - EST - E.C. 3.1.1.1)

- Glutamato Desidrogenase (GDH-E.C.1.4.1.3)

- Shiquimato Desidrogenase (SKDH-E.C.1.1.1.25)

- Malato Desidrogenase (MDH-E.C.1.1.1.37)

- Isocitrato Desidrogenase (IDH-E.C.1.1.1.42)

- Fosfatase Ácida (ACP-E.C.3.1.3.2)

- Álcool Desidrogenase (ADH-E.C.1.1.1.1)

- Peroxidase (PER-E.C.1.11.1.7)

- Fosfoglucose Isomerase ( PGI- E.C.5.3.1.9)

- Fosfoglucomutase (PGM E.C.2.7.5.1)

- Glutamato-Oxaloacetato Transaminase (GOT E.C.2.6.1.1)

- Glucosè-6-Fosfato- Desidrogenase (G6PDH-E.C.1.1.1.49) 
- Glucose Desidrogenase (GLUDH-E.C.1.1.1.47)

- Fosfogluconato Desidrogenase (6PGDH-E.C.1.1.1.44)

Os sistemas que apresentaram separação nítida de bandas, boa definição e ausência de rastro e, portanto, selecionados para o estudo, foram: PGI, PGM, MDH, SKDH, PER e LAP. Os protocolos são detalhados a seguir:

$$
\begin{aligned}
& \text { - PGI: }
\end{aligned}
$$

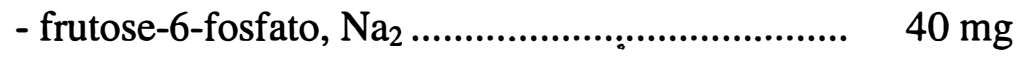

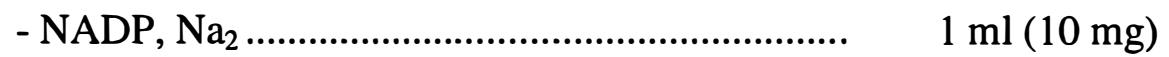

$$
\begin{aligned}
& \text { - MTT …………………………………..... } 1 \mathrm{ml}(10 \mathrm{mg}) \\
& \text { - PMS ….......................................................... } 1 \mathrm{ml}(1 \mathrm{mg})
\end{aligned}
$$

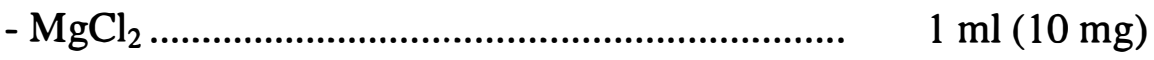

$$
\begin{aligned}
& \text { - glucose-6-fosfato desidrogenase ....................... } 0,02 \mathrm{ml} \\
& \text { - Tris- } \mathrm{HCl} 0,1 \mathrm{M}, \mathrm{pH} 8,0 \ldots \ldots \ldots \ldots \ldots \ldots \ldots \ldots \ldots \ldots \ldots \ldots . . . \quad 50 \mathrm{ml}
\end{aligned}
$$

Adicionar o G6PDH por último e incubar o gel no escuro por $45 \mathrm{~min}$, à temperatura de $30^{\circ} \mathrm{C}$.

$$
\begin{aligned}
& \text { - PGM: }
\end{aligned}
$$

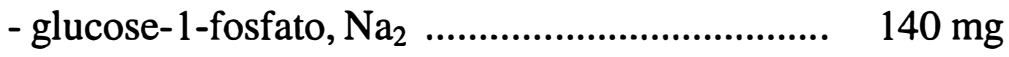

$$
\begin{aligned}
& \text { - EDTA …………………………….............. } 25 \mathrm{mg}
\end{aligned}
$$

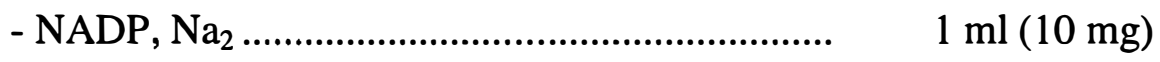

$$
\begin{aligned}
& \text { - MTT …............................................................ } 1 \mathrm{ml}(10 \mathrm{mg})
\end{aligned}
$$

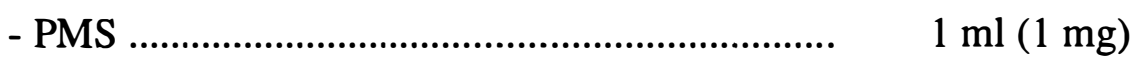

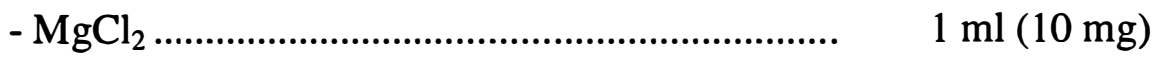

$$
\begin{aligned}
& \text { - glucose-6-fosfato desidrogenase ........................ 0,02 ml } \\
& \text { - Tris-HCl 0,1M, pH 8,5 ...................................... } 50 \mathrm{ml}
\end{aligned}
$$


Adicionar o G6PDH por último e incubar o gel no escuro por $45 \mathrm{~min}$, à temperatura de $30^{\circ} \mathrm{C}$.

\section{-MDH:}

- DL- ácido málico 0,5M, pH 8,0 .................... 04 ml

- MTT ............................................................ $1 \mathrm{ml}(10 \mathrm{mg})$

- NAD ....................................................... $1 \mathrm{ml}(10 \mathrm{mg})$

- PMS ........................................................ $1 \mathrm{ml}(10 \mathrm{mg})$

- tampão Tris-HCl 0,1M, pH 8,5 .................................50 ml

Adicionar todos os reagentes no Tris, cobrir o gel com a solução e incubar por $40 \mathrm{~min}$, à temperatura de $30^{\circ} \mathrm{C}$.

\section{- SKDH:}

- ácido xiquímico $70 \mathrm{mg}$

- MTT $1 \mathrm{ml}(10 \mathrm{mg})$

- NADP, $\mathrm{Na}_{2}$ $1 \mathrm{ml}(10 \mathrm{mg})$

- PMS $1 \mathrm{ml}(10 \mathrm{mg})$

- Tris- $\mathrm{HCl} 0,1 \mathrm{M}, \mathrm{pH} 8,0$ $50 \mathrm{ml}$

Adicionar todos os reagentes no Tris, cobrir o gel com a solução e incubar por 24 horas à temperatura de $30^{\circ} \mathrm{C}$.

\section{- PER:}

- O-Dianisidina $30 \mathrm{mg}$

- Etanol $25 \mathrm{ml}$

- Tampão acetato de sódio e 0,2M, pH 5,0 ........ 25 ml

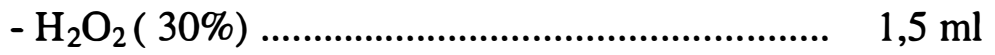

Agitar o etanol e a dianisidina, adicionar o acetato e incubar por 30 min à temperatura de $30^{\circ} \mathrm{C}$. Adicionar $1,5 \mathrm{ml} \mathrm{de} \mathrm{H}_{2} \mathrm{O}_{2}(30 \%)$. 


\section{- LAP:}

- L- leucina ........................................................ $30 \mathrm{mg}$

- fast black ......................................................... $50 \mathrm{mg}$

- tampão tris-maleato pH 5,4 _.............................................20 ml

- água destilada ..................................................... $50 \mathrm{ml}$

Diluir a leucina e o fast black em $2 \mathrm{ml}$ de metanol, adicionar o tampão e incubar por 24 horas à temperatura de $30^{\circ} \mathrm{C}$.

As receitas dos sistemas enzimáticos adaptadas para C. speciosa, a partir de Alfenas et al (1991).

\subsubsection{Condições da corrida}

A migração das isoenzimas se deu em gel horizontal, mantido em refrigerador a $4^{\circ} \mathrm{C}$. Durante a corrida permanecia uma corrente de 8 a $10 \mathrm{~mA}$ no gel (voltagem: $\pm 200 \mathrm{~V}$ ) nos primeiros 30 minutos, quando então os "wicks" eram retirados e a corrente no gel era aumentada para $25 \mathrm{~mA}$ (voltagem $: \pm 300 \mathrm{~V}$ ).

O tempo de corrida foi aproximadamente 8 horas, quando o marcador de bromofenol atingia de 7,5 a $8,0 \mathrm{~cm}$ de migração. Completada esta etapa, o gel foi cortados em cinco fatias, a primeira foi descartada e as subsequientes utilizadas para coloração. 


\subsubsection{Leitura dos zimogramas}

Todo material foi fotografado em preto e branco, para posterior interpretação, as bandas foram desenhadas em filmes plásticos com canetas de retroprojetor, de modo a se preservar suas dimensões originais. Além disso, utilizou-se uma amostra de referência, que foi colocada em cada gel para auxiliar a identificação correta dos alelos.

O sistema isoenzimático Peroxidase apresentou 2 locos legíveis com diferentes tempos de revelação; neste caso a leitura do loco 2 foi feita no final da corrida, diretamente no gel. Este loco, por ser monômero e com 2 alelos, foi de fácil leitura.

O loco que controlou a enzima de maior distância de migração, a partir da origem, foi denominado de loco 1 (exemplos: MDH-1, LAP-1 etc). Os alelos foram identificados de acordo com a distância de migração, sendo aquele com maior distância designado de alelo 1 . Os demais alelos em cada loco foram identificados de acordo com a distância em que as respectivas bandas se posicionavam em relação ao alelo 1, podendo ser 2,3 ou 4 . Os locos mal definidos foram descartados.

\subsection{Metodologia Utilizada para Fragmentação da População da Reserva}

A metodologia desenvolvida para verificar as implicações genéticas de um gargalo ("Bottlenecks") na população da Reserva, consistiu no reagrupamento dos dados em diferentes categorias de tamanho populacional. Este remanejamento teve como critério agrupar os indivíduos que estão mais próximos espacialmente, ou seja os subgrupos formados representam no campo subpopulações contínuas. Os dados rearranjados foram novamente submetidos às análises estatísticas feitas pelo programa BIOSYS (Swofford \& Selander, 1989). 
As categorias simulam diferentes intensidades de corte de árvores da população da Reserva, que possui um total de 53 árvores, são estas:

-Categoria I: simulou-se o corte de $75 \%$ das árvores. Os dados foram reagrupados formando-se 4 subpopulações, cada uma com 13 ou 14 árvores, ou seja cada subpopulação representa $25 \%$ da população original. Esta categoria foi designada de Fr$25 \%$. (Figura 1)

-Categoria II: simulou-se o corte de 50\% das árvores. Os dados foram reagrupados formando-se 2 subgrupos, com 26 e 27 árvores cada. Esta categoria foi designeda de Fr-50\%. (Figura 2)

-Categoria III: simulou-se o desbaste seletivo das árvores, assim todos os indivíduos com DAP superior a $60 \mathrm{~cm}$ foram eliminados das análises. Esta categoria designou-se $\mathrm{Cs} \geq 60$. (Figura 3 ) 


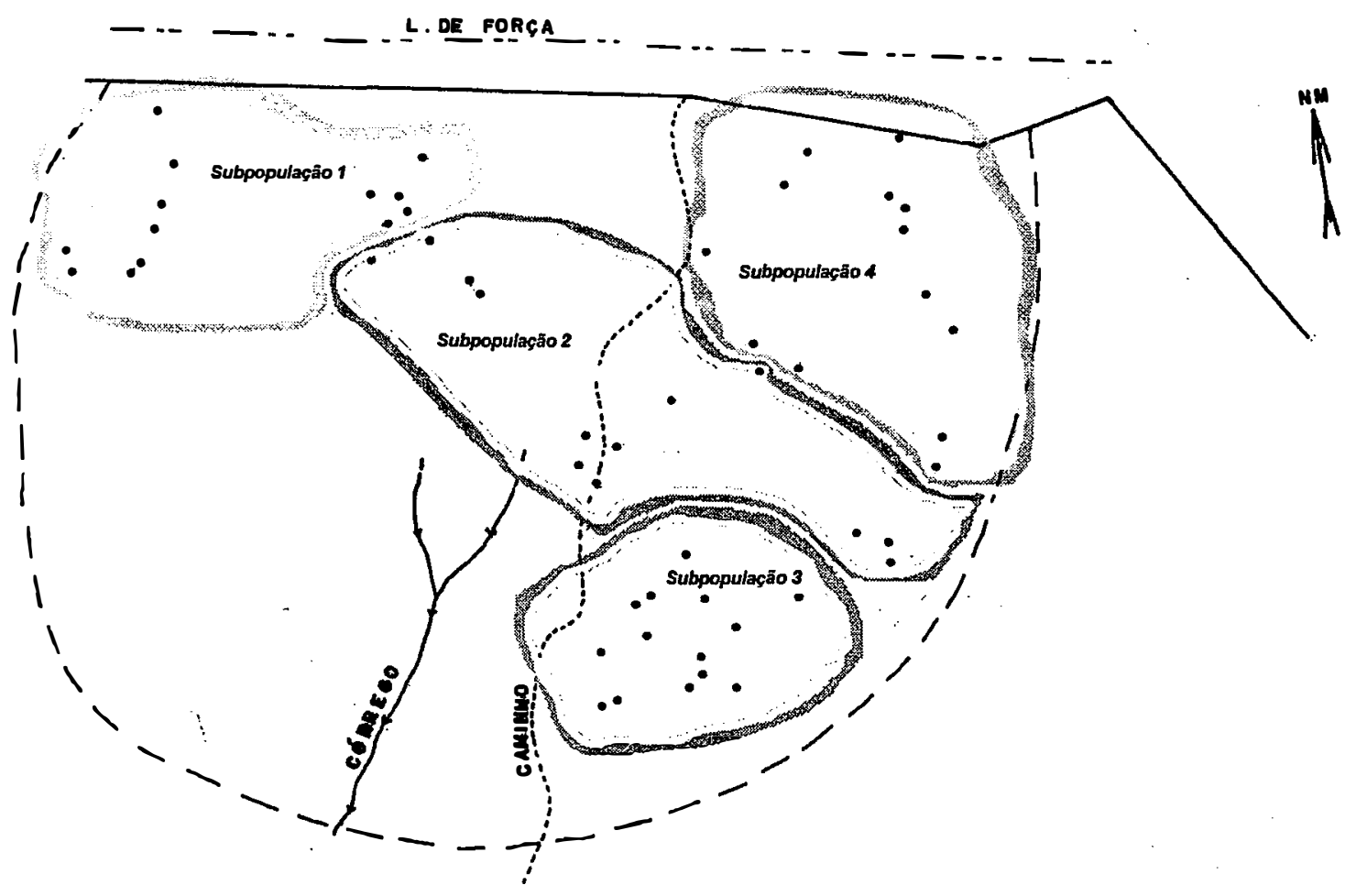

Fígura 1. Distribuição espacial da categoria I com 4 subpopulações: Subpopulação $1=13$ árvores, Subpopulação $2=13$ árvores, Subpopulação $3=14$ árvores, Subpopulação $4=13$ árvores, simulando o corte de $75 \%$ das árvores. 


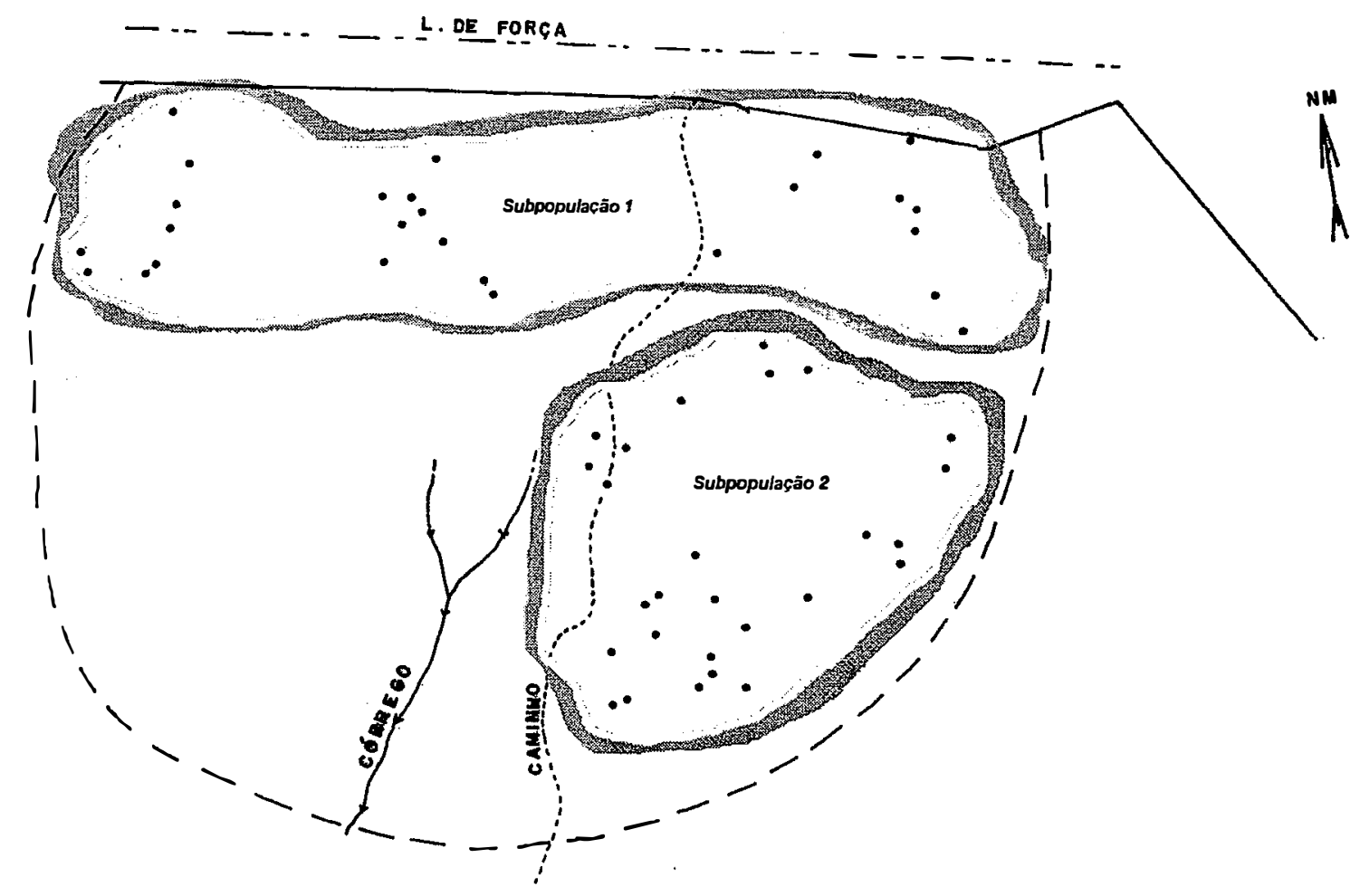

ESTACAOECOLÓGICA DE BAURU-SP

FAZENDA SÃO LUIZ,

POPULACAO AMOSTRADADE C. speciosa F

AREA TOTAL DARESERVA $=287,00, \mathrm{ha}$,

AREA ANOSTRADA =,$\quad 5000 \mathrm{ha}$,

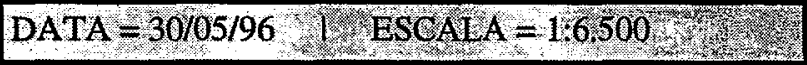

Figura 2. Distribuição espacial da categoria II com 2 subpopulações: Subpopulação $1=26$ árvores, Subpopulação $2=27$ árvores, simulando o corte de 50\% da população original. 


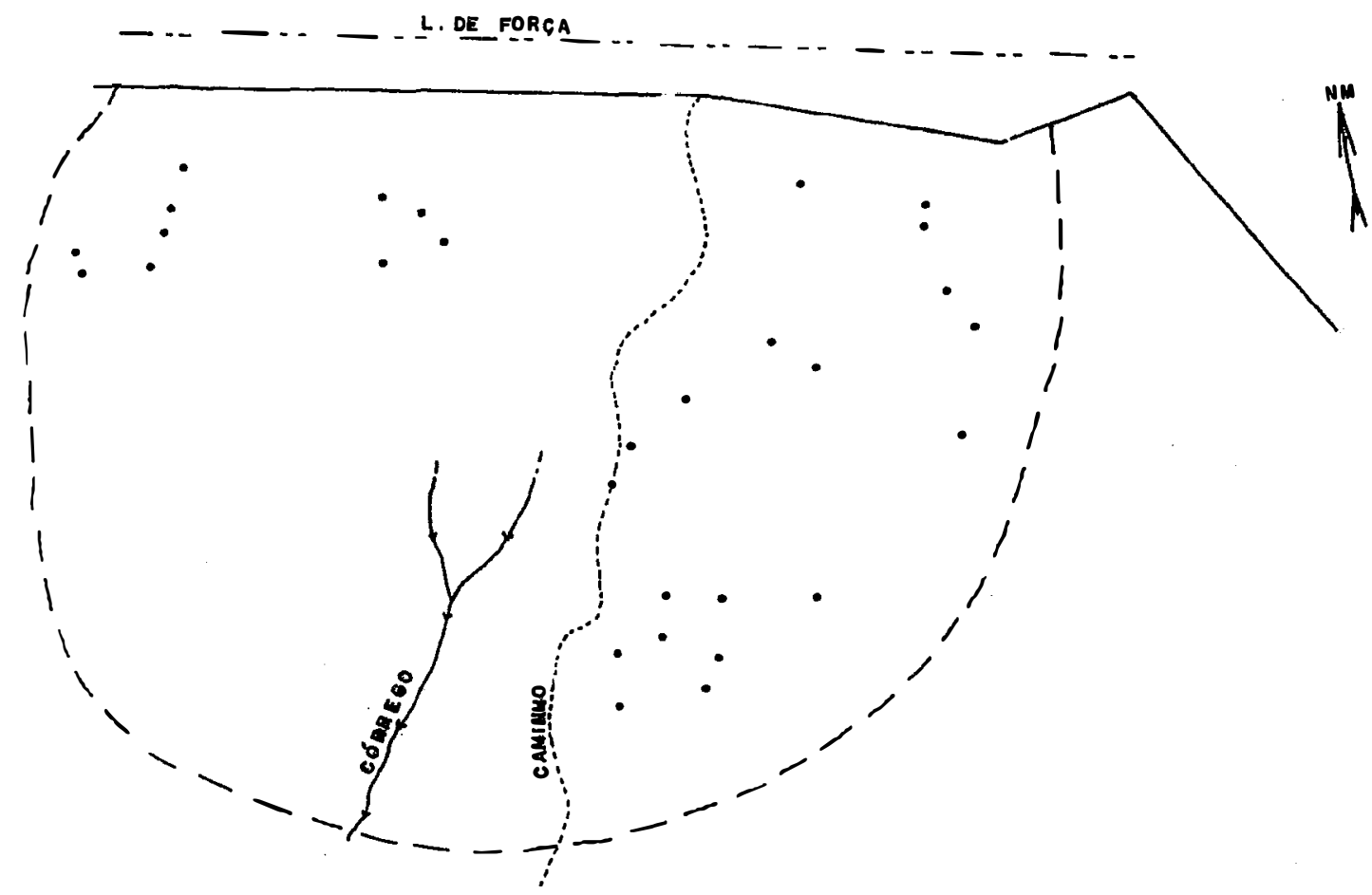

ESTAÇ̃̃O ECOLOGGICA DE BAURU-SP

FAZZENDA SÁOLUIZ

3.

POPULACÃO AMOSTRADA DE C speclosa

AREA TOTAL DA RESERVA $=287,00 \mathrm{ha}$

AREA AMOSTRADA =

AREA AMOSTRADA =

50,00 ha

DATA $=30 / 05 / 96 \quad$ ESCAL $A=1,6.500$

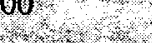

Figura 3. Distribuição espacial da categoria III com 1 subpopulação $=29$ árvores, simulando o corte das árvores com DAP $>60 \mathrm{~cm}$. 


\subsection{Metodologia Estatística}

\subsubsection{Caracterização da Variação Genética}

Para estimar os parâmetros que medem a diversidade genética foi utilizado o programa BIOSYS (Swofford \& Selander, 1989), que fornece estimativas das freqüências alélicas e genotípicas; a heterozigosidade média observada e esperada por loco em cada população $\left(\hat{\mathrm{H}}_{\mathrm{o}}, \hat{\mathrm{H}}_{\mathrm{e}}\right)$; número médio de alelos por loco $(\mathrm{A})$; a porcentagem de locos polimórficos (P), as estatísticas $F$ de Wright $(1965,1978)$ por loco e para a população $\left(\hat{F_{i s}}, \hat{F_{i t}}\right.$ e $\left.\hat{F}_{s t}\right)$, calcula os desvios das freqüências genotípicas em relação ao equilíbrio de Hardy-Weinberg e calcula a distância genética de Nei (1972) entre populações.

Estes parâmetros forma estimados para populações de árvores adultas situadas nos diferentes fragmentos e para as famílias obtidas em uma população que representa um fragmento grande e não perturbado. Através deste programa foram analisadas as populações situadas nas 4 áreas : Reserva, Santa, Laranja e Shangrilá e as subpopulações artificiais originárias da população da Reserva (Fr-25\%, Fr-50\% e Cs $\geq$ $60)$.

A diversidade gênica ou heterozigosidade esperada $\left(\mathrm{H}_{e}\right)$, conforme Nei (1973), refere-se ao nível de heterozigosidade de uma população obtido a partir de freqüências alélicas desta. Este valor equivale à quantidade de heterozigotos esperada, segundo as pressuposições do Teorema de Hardy-Weinberg. Esta medida pode representar a variação, tanto em populações de espécies alógamas quanto autógamas.

A heterozigosidade observada é calculada diretamente da amostra a partir das frequiências genotípicas, podendo ser estimada para um ou mais locos (Brown \& Weir, 1983).

A porcentagem de locos polimórficos (P) avalia o grau de polimorfismo encontrado na amostra. Designa-se loco polimórfico aquele cuja frequiência do alelo mais comum é igual ou menor que 0,99 ou 0,95 (Futuyma, 1992). 
O número médio de alelos por loco (A) é uma estatística que enfatiza a riqueza alélica. Representa uma quantidade definida e espera-se ser grande quando a amplitude do polimorfismo for grande. Possui forte dependência do tamanho amostral (Nei,1987).

O índice de fixação ou coeficiente de endogamia $(\hat{F})$ é obtido pela relação entre frequiências observadas $\left(\hat{\mathrm{H}}_{\mathrm{o}}\right.$ e esperadas $\left(\hat{\mathrm{H}}_{\mathrm{e}}\right)$ de heterozigotos, e portanto mede a fração de redução da heterozigosidade em relação ao esperado pelo Equilíbrio de HardyWeinberg (E.H.W.). Valores de $\hat{F}$ iguais a zero indicam que a população está em E.H.W. e valores significativamente maiores ou menores que zero excesso de homozigotos ou heterozigotos, respectivamente (Wright, 1951, 1965).

Quando há subdivisão de população, ou alguma estrutura hierárquica, o índice de fixação passa a ser representado por $\hat{F}_{i s}$ que é o índice de fixação médio entre indivíduos dentro da população ou subpopulação; $\hat{F}_{i t}$ que é o índice de fixação total para a espécie e $\hat{F}_{s t}$ que é uma medida de distância genética e define a divergência entre populações em termos de freqüência gênica (Wright, 1951).

Para testar se os valores de $\hat{F}$ foram significativamente diferentes de 0 (zero) utilizaram-se duas estatísticas $x^{2}$; i) para testar significâncias do $\hat{F}_{i s}$ e $\hat{F}_{i t}$, o teste de Workman \& Niswander (1970) e ii) para testar significâncias do $\hat{F}_{s t}$ o teste Li \& Horvitz (1953).

O programa BIOSYS calcula o desvio da distribuição dos genótipos observados, dos esperados de acordo com as pressuposições do equilíbrio de HardyWeinberg, fazendo uso de três testes: i) $x^{2}$ utilizando-se todos os genótipos individualizados (não agrupado), ii) $x^{2}$ agrupando-se genótipos em 3 classes (classe 1: número de homozigotos para o alelo mais comum, classe 2: número de heterozigotos entre o alelo mais comum e mais raro e classe 3: número de homozigotos raros e outros heterozigotos.) e iii) teste exato de Fisher. O critério para a seleção do teste apropriado foi a verificação das freqüências genotípicas esperadas, que deveriam ser maiores que 5 (cinco), ou seja, de acordo com Gomes (1990), a freqüência esperada não deve ser menor 
que 1 e em poucos casos menor que 5. Quando estas regras não funcionam para os testes de $x^{2}$ utiliza-se o teste exato de Fisher.

\subsubsection{Determinação da Taxa de Cruzamento}

Para estimativa da taxa de cruzamento, foram utilizados as frequiências gênicas e genotípicas relativas à população situada na Reserva, segundo a metodologia proposta por Ritland \& Jain (1981), que se baseiam em estimativas de máxima verossimilhança. Foram analisadas 26 famílias obtidas a partir de sementes coletadas de 26 árvores e constituídas por 20 indivíduos cada.

Para tanto foi utilizado o programa "Multilocus" (MLTR), desenvolvido por Ritland (1996), o qual estima os seguintes parâmetros:

- taxa de cruzamento multilocos para população e famílias, $\left(\hat{t}_{\mathrm{m}}\right)$

- taxa de cruzamento para cada loco, $\left(\hat{t}_{\mathrm{s}}\right)$

- frequiências alélicas de pólen (p) e óvulo

- variâncias das estimativas acima, usando o método de Bootstrap, onde as plântulas dentro das famílias são unidades de reamostragem, obtendo-se então os desvios padrões a 95\% de intervalo de confiança e, com isso, a significância dos valores das taxas de cruzamento.

- inferência de genótipos maternais

O programa se baseia nos seguintes pressupostos:

- Todos os genótipos maternais cruzam na mesma taxa a partir de um conjunto de pólen homogêneo na população;

- Alelos de diferentes locos segregam independentemente;

- Segregação dos alelos em plantas maternais heterozigotas é estritamente mendeliana em uma razão de 1:1, tanto para pólen, quanto para óvulo;

- Os marcadores genéticos não são afetados por seleção e mutação entre o tempo de cruzamento e a amostragem das progênies. 


\subsubsection{Estrutura genética espacial}

A autocorrelação espacial verifica se os genótipos apresentam distribuição aleatória ou estruturada, ou seja, neste último caso se as árvores que estão próximas podem ser mais semelhantes ou completamente diferentes (Sokal \& Oden, 1978).

Para investigar a estrutura genética espacial foi feita a análise de Autocorrelação Espacial, utilizando-se os genótipos individuais dos locos polimórficos de cada matriz. Para isto, utilizou-se o programa "Autocorr" desenvolvido por John S. Heywood. Os critérios matemáticos e a utilização do programa podem ser vistos de forma mais detalhada em Sokal \& Oden (1978), sendo que uma revisão do assunto se encontra em Gandara (1996).

O programa oferece 5 ponderações para o cálculo do índice I de Moran, que quantifica a similaridade genética de pares de indivíduos adjacentes em relação à amostra da população como um todo. Este índice pode assumir valores entre +1 (autocorrelação positiva completa, ou seja os indivíduos pareados são idênticos), -1 (autocorrelação negativa completa, ou seja, os indivíduos pareados são completamente diferentes) e quando o valor é próximo a 0 (zero) significa a aleatoriedade na distribuição dos genótipos. Foram feitos testes de significância para verificar se os valores de I foram diferentes de zero (teste $\mathrm{z}$ ).

Neste trabalho, foram utilizadas as comparações de vizinhos mais próximos, conexão de Gabriel e todas as comparações dentro de uma classe de distância especificada (autocorrelogramas). 


\section{RESULTADOS E DISCUSSÃO}

Este item é dividido em 2 partes:

-Estrutura genética da população situada na Estação Ecológica de Bauru (Reserva). Esta representa uma população não perturbada, em um fragmento grande e bem conservado. Nesta parte serão discutidos além dos índices de diversidade genética, as taxas de cruzamento e a existência de autocorrelação espacial.

-Estrutura genética de populações fragmentadas. Nesta parte serão feitos 2 modelos de análises: i) análise de subpopulações artificiais criadas a partir da população da Reserva e ii) análise comparativa dos índices de diversidade genética de 4 fragmentos, além do fragmento da Reserva, mais 3 fragmentos florestais pequenos e perturbados.

\subsection{Estrutura genética da população situada na Estação Ecológica de Bauru}

\subsubsection{Distribuição Espacial}

A área amostrada abrangeu 50 hectares, nela foram encontrados 56 indivíduos adultos de C. speciosa, cujo DAP variou entre 35 a $134 \mathrm{~cm}$. Destes, 53 árvores foram usadas nas análises estatístico-genéticas. A distribuição espacial das árvores sugere uma tendência a agregação (figura 4).

Considerando a informação de que a área total da Reserva (287 ha) possui 92 árvores adultas ( $\mathrm{Sr}$ Adopho Dario - responsável técnico pela Reserva de Bauru, comunicação pessoal) estima-se a densidade 0,321 árvores por hectare. A densidade estimada na área amostrada (50 ha) é 1 indivíduo por hectare. 


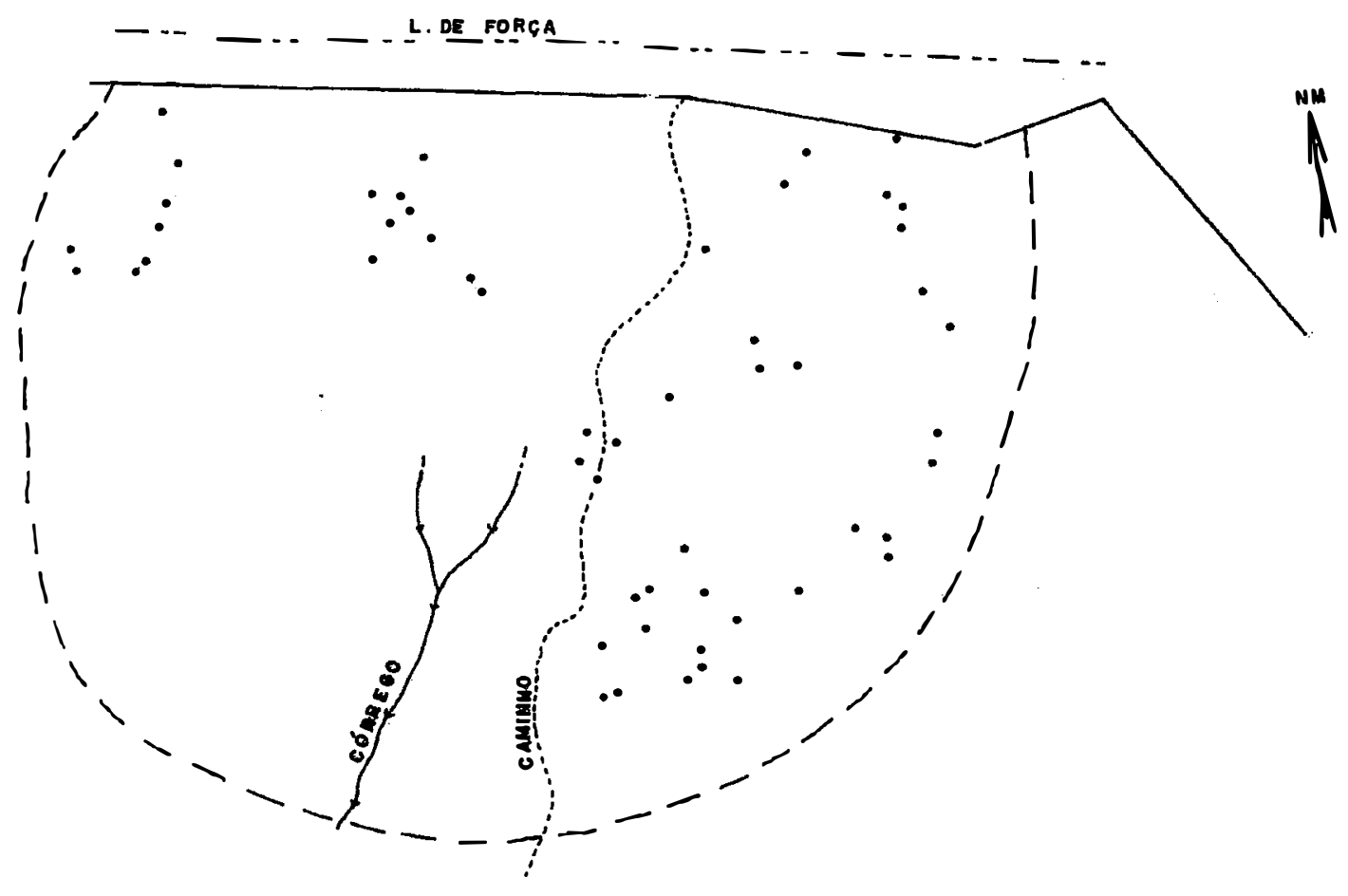

ESTAÇÃO ECOLÓGICA DE BAURU-SP

EAZENDA SÃOLUTZ

PORULACAO AMOSTRADA DECG spectóso (1)

AREA TOTALDARESERVA $=28700 \mathrm{ha}$

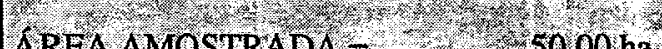

AREA AMOSTRAOA =

DATA $=30 / 05 / 96 \quad / \quad$ ESCALA $=1: 6.500$

Figura 4. Localização dos 53 indivíduos adultos de $C$. speciosa na área de estudo. 


\subsubsection{Análises Laboratoriais}

Em relação aos testes preliminares, os seguintes resultados foram encontrados:

- a espécie não tolerou armazenamento em freezer ou em nitrogênio líquido das folhas e extratos originários das mudas;

- extratos de folhas de árvores adultas toleram no máximo 3 dias de armazenamento em freezer $-80^{\circ}$;

- as folhas das árvores toleram 10 dias de armazenamento em geladeira;

- a maceração mais adequada foi com nitrogênio líquido;

- a centrifugação do extrato facilita a embebição do "wick", porém o resultado final não se diferencia das amostras não submetidas à centrifugação;

- as folhas em início de brotação (folhas tenras, de coloração verde clara e com $2 \mathrm{~cm}$ de comprimento) não apresentam resolução de bandas e são rapidamente oxidadas quando maceradas;

- as folhas das árvores adultas, quando inseridas no mesmo gel das folhas das mudas, prejudicam a resolução destas últimas.

\subsubsection{Interpretação Genética dos Zimogramas}

Foi encontrado o seguinte padrão de distribuição para os zimogramas:

- Fosfoglucose isomerase (PGI): apresentou 2 regiões de atividade, sendo a mais catódica com péssima resolução e a mais anódica, PGI-1, com enzimas dímeras e 4 alelos, foi interpretada.

- Fosfoglucomutase (PGM): mostrou 2 regiões de atividade. A banda mais catódica foi descartada devido à sobreposição de bandas que gerava muitas dúvidas para leitura. O loco legível, PGM-1, com enzimas monômeras e 3 alelos. 
- Malato desidrogenase (MDH): revelou 4 regiões de atividade, sendo 2 locos monomórficos (MDH-1 e MDH-2), uma região heterodimérica (entre MDH-2 e MDH-3) e um loco polimórfico (MDH-3). Este loco com enzimas diméricas e 3 alelos.

- Xiquimato desidrogenase (SKDH): com 1 região de atividade, com enzima monomérica e 3 alelos (SKDH-1).

- Peroxidase (PER): com 2 regiões de atividade nítidas, uma anódica (PER-2) e outra catódica (PER-1) e entre estas, uma região indistinta com várias bandas. PER-1 e PER-2 possuem enzimas monoméricas e 2 alelos.

- Leucina aminopeptidase (LAP): apresentou uma região de atividade (LAP-1), com enzima monomérica e 2 alelos.

Estas interpretações constam da Figura 5 e são consistentes com os padrões encontrados em outras espécies, principalmente no que se refere à estrutura das enzimas, número de locos e número de alelos por loco.

No total foram analisados 9 locos, sendo 2 monomórficos, na população da Reserva e 8 locos, com 2 monomórficos para análise conjunta dos 4 fragmentos. Neste último caso a enzima LAP foi descartada por não ter tido boa resolução para as amostras dos 3 fragmentos (Santa, Laranja e Shangrilá). 

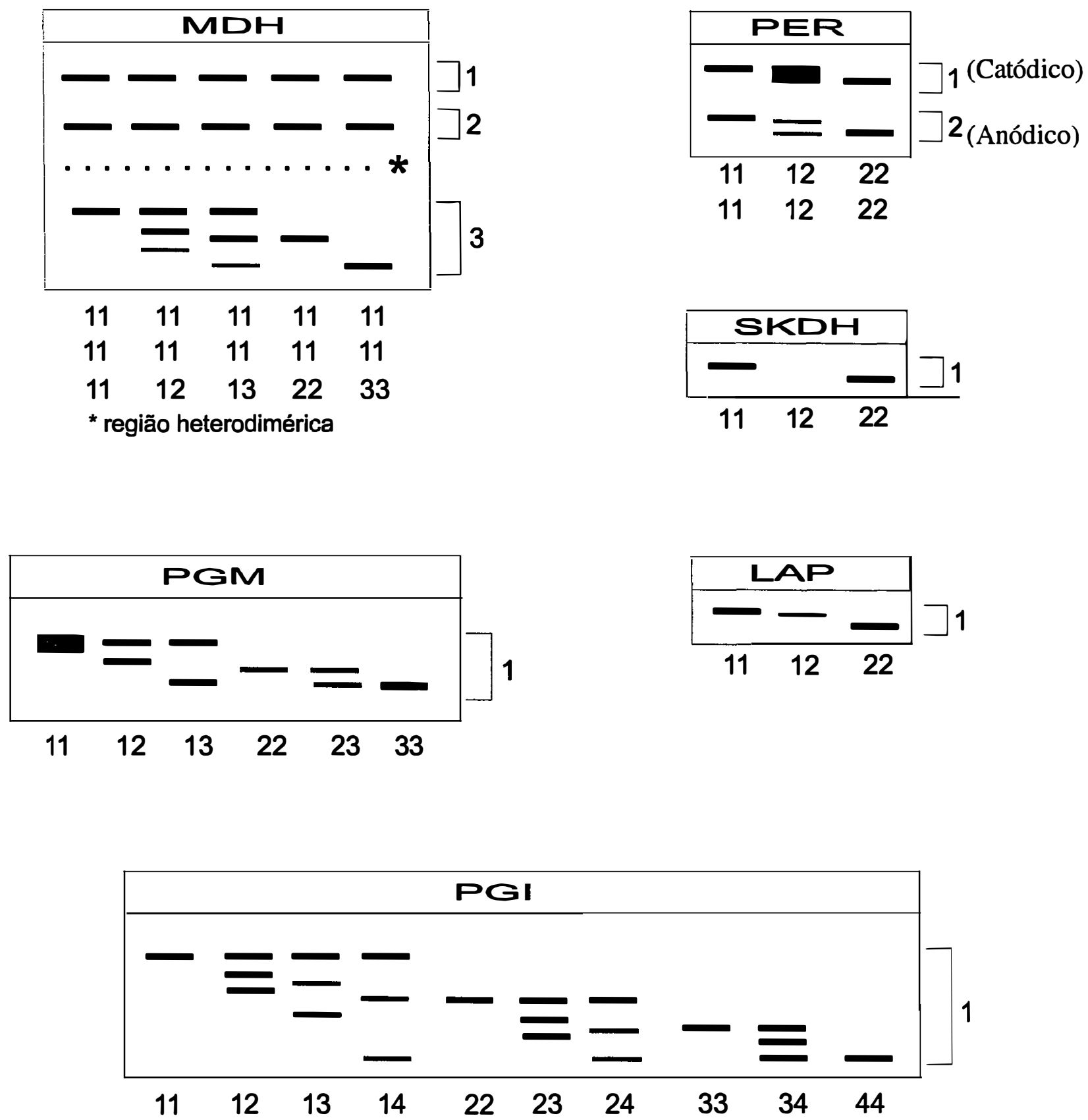

Figura 5. Esquema dos zimogramas dos padrões eletroforéticos oriundos de uma população natural de $C$. speciosa, para 9 locos e 6 sistemas enzimáticos.

N.o 69.216

U SP - Campus de Piracicaba DIVISĀO DE BIBLIOTECA

E DOCUMENTAÇÃO 


\subsubsection{Análise para Variação Genética}

Foram analisados ao todo 9 locos isoenzimáticos, onde 2 (MDH-1 e MDH-2) apresentaram-se monomórficos, tanto para adultos quanto para famílias e 7 locos mostraram-se polimórficos para todas as amostras. Foram encontrados 20 alelos, sendo estes observados tanto nos adultos quanto nas famílias (tabela 2). Tal fato pode estar indicando a possibilidadede não ter ocorrido fluxo gênico de outros alelos de fora da amostragem das progênies, no evento reprodutivo estudado.

As proporções das frequiências alélicas firmaram-se equivalentes para adultos e famílias, ou seja, estes valores não foram discrepantes. Por exemplo, o alelo 4 da PGI1 mostrou-se raro tanto para adultos, quanto nas famílias; os alelos 1 da PGI-1 e o alelo 1 da MDH-3 se mostraram freqüentes nos adultos e nas famílias (tabela 2).

Conforme mostra a tabela 2, a heterozigosidade média observada nos adultos e nas famílias da população de $C$. speciosa foi respectivamente $0,245( \pm 0,068)$ e 0,202 $( \pm 0,063)$ e a heterozigosidade média esperada foi $0,284( \pm 0,074)$ e $0,266( \pm 0,073)$. As estimativas não diferiram estatisticamente. Existe uma tendência de a heterozigosidade alcançar maiores valores em adultos, que sugere mecanismo seletivo atuando em favor dos heterozigotos. Este fato foi observado em outros trabalhos tais como: Hamrick et al (1993) estudando 3 espécies arbóreas tropicais, Alvarez-Buylla \& Garay (1994) observaram tal fato em populações de Cecropia obtusifolia, Gandara (1996) estudando Cedrela fissilis e Lepsch-Cunha (1996) estudando 2 espécies de Couratari.

$\mathrm{O}$ valore médio de $F_{i s}$ em indivíduos adultos e famílias indica esta tendência, pois o valor obtido para as progênies $(0,239)$ foi significativo e maior que aquele encontrado para os adultos $(0,130)$. $\mathrm{O}$ excesso de homozigotos é significativo somente para as progênies, sugerindo endogamia presente no evento reprodutivo estudado. Murawski et al (1990)também observaram para 2 espécies de Bombacaceae os valores de $F_{i s}$ superiores para as progênies. Murawski (1996), citando diversos autores verifica esta tendência para outras espécies arbóreas tropicais. 
Tabela 2. Freqüências alélicas e índices de diversidade genética para adultos e famílias de uma população natural $C$. speciosa situada na Reserva, baseadas em 9 locos e seis sistemas enzimáticos (os números entre parênteses referem-se aos desvios padrões).

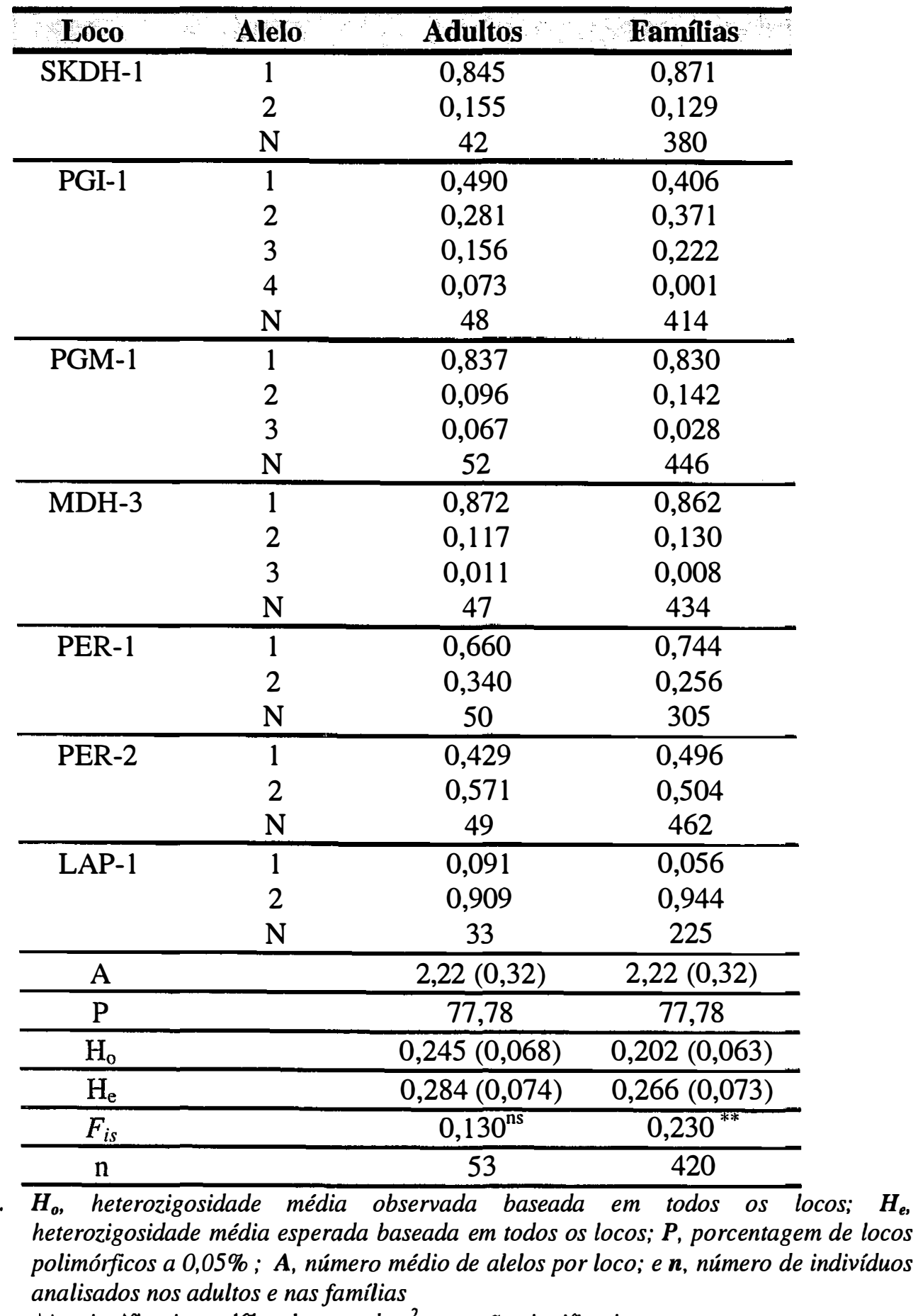

2. ** - significativo a $1 \%$ pelo teste de $x^{2} ; n s$ - não significativo. 
A tabela 3 compara os valores estimados dos parâmetros genéticos: porcentagem de locos polimórficos $(\mathrm{P})$, número médio de alelos por loco $(\mathrm{A}) \mathrm{e}$ heterozigosidade média esperada $\left(\mathrm{H}_{\mathrm{e}}\right)$ de 4 espécies de Bombacaceae incluindo $C$. speciosa.

Tabela 3. Estimativa de parâmetros genéticos relativos a algumas espécies arbóreas que pertencem à família Bombacaceae.

\begin{tabular}{|c|c|c|c|c|}
\hline Espécie & $\mathbf{P}$ & $\mathbf{A}$ & $\mathrm{H}_{\mathrm{e}}$ & 7ै Densidade \\
\hline $\begin{array}{c}\text { Quararibea } \\
\text { asterolepis }^{\text {e } 2}\end{array}$ & 64 & 1,99 & 0,256 & $2 \mathrm{ind} / \mathrm{ha}$ \\
\hline $\begin{array}{c}\text { Cavallinesia } \\
\text { platanifolia }^{1,2} \text { e }^{3}\end{array}$ & 31 & - & 0,123 & $0,10 \mathrm{ind} / \mathrm{ha}$ \\
\hline Ceiba pentandra ${ }^{2 e 4}$ & 30,8 & 2,4 & 0,106 & $0,24 \mathrm{ind} / \mathrm{ha}$ \\
\hline Chorisia speciosa & 77 & 2,2 & 0,284 & $1 \mathrm{ind} / \mathrm{ha}$ \\
\hline
\end{tabular}

1- Murawski et al (1990)

2- Murawski \& Hamrick (1991)

3- Murawski \& Hamrick (1992a)

4- Murawski \& Hamrick (1992b)

Os valores de $\mathrm{P}$ em $C$. speciosa foram superiores às três espécies comparadas e mais próximo do valor encontrado para $Q$. asterolepis. O valor de A equivalente nos três casos. A heterozigosidade esperada de $C$. speciosa foi superior as três espécies comparadas, sendo mais próximo de $Q$. asterolepis. Esta tabela mostra uma maior similaridade entre os parâmetros de $C$. speciosa e $Q$. asterolepis. As duas espécies mais raras apresentaram praticamente a metade dos valores de $\mathrm{P}$ e $\mathrm{H}_{\mathrm{e}}$ encontrado para $C \cdot$ speciosa. Em termos de densidade, C. speciosa situa-se numa classe intermediária entre as Bombacaceae mais raras (C. platanifolia e $C$. pentandra) e a mais comum $(Q$. asterolepis). 
A heterozigosidade esperada desta população de $C$. speciosa pode ser considerada alta quando comparada a outras espécies vegetais. Murawski \& Hamrick (1991) encontraram para as espécies tropicais um valor médio equivalente a 0,146 , nas espécies comuns 0,136 e nas espécies raras este valor foi 0,157. Este último número variou entre 0,062 e 0,205. Hamrick \& Godt (1990) encontraram para as espécies polinizadas por animais e com dispersão pelo vento um valor médio de 0,123 .

A heterozigosidade média esperada está mais próxima dos valores encontrados por Paiva et al (1994), que obtiveram 0,241 para Hevea brasiliensis, Loveless \& Hamrick (1987), estudando 8 espécies arbóreas tropicais, encontraram 0,240 de heterozigosidade; Gandara (1996) encontrou para Cedrela fissilis 0,243; LepschCunha (1996) encontrou valores superiores para Couratari guinensis e Couratari multiflora, respectivamente 0,429 e 0,436; O’Malley \& Bawa (1987) em Pithecellobium pedicelare, uma espécie arbórea de baixa densidade, polinizada por animais e dispersa pelo vento, encontrou 0,358. A heterozigozidade média esperada potencial em $C$. speciosa (que apresentou em média 2 alelos/loco) é de 0,500 , mostrando que o valor encontrado atingiu pouco mais que a metade do precedente.

A tabela 4 mostra os desvios do Equilíbrio de Hardy- Weinberg (EHW) para adultos e famílias, utilizando-se comparativamente, quando possível, os três testes: $x^{2}$ agrupado, $x^{2}$ não agrupado e Teste Exato de Fisher. 


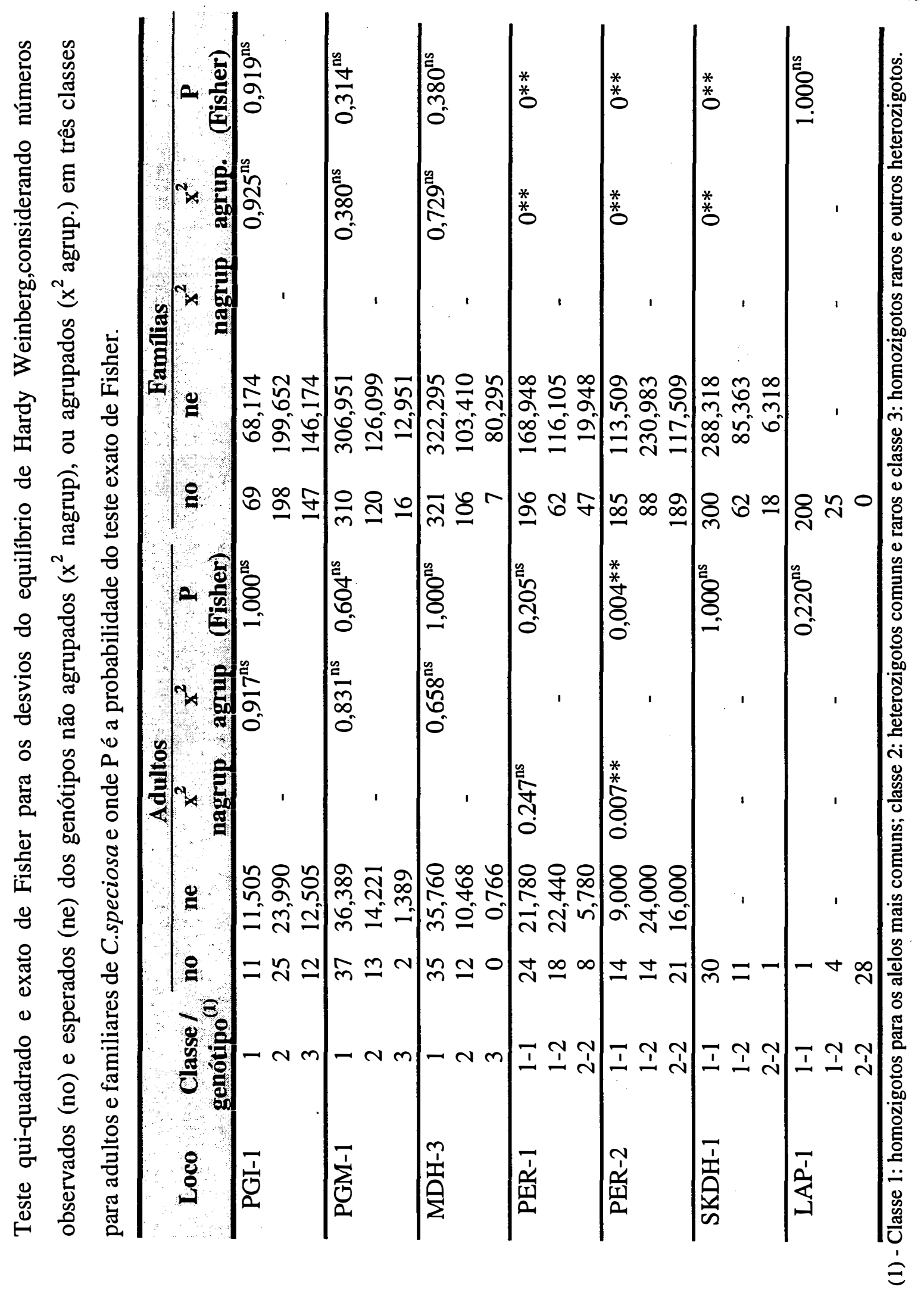

$\frac{\pi}{8}$ 
Na população adulta de $C$. speciosa ocorreu a rejeição da hipótese nula do EHW em apenas um loco (PER-2). Nas famílias verificou-se a rejeição desta hipótese em três locos (PER-1, PER-2 e SKDH-1), sendo que todos os desvios encontrados foram por excessos de homozigotos, indicando a presença de endogamia nesta população.

Este resultado sugere que a população adulta está em equilíbrio de panmixia, mas que as famílias originárias do ciclo reprodutivo analisado não estão oriundas de cruzamentos aleatórios. Gandara (1996), Reis (1996), Moraes (1997) também encontraram esta tendência para as espécies Cedrela fissilis, Euterpe edulis e Cryptocarya moschata, respectivamente. Esta tendência não foi verificada para 2 espécies de Couratari, que segundo Lepsch-Cunha (1996) apresentaram maiores desvios de panmixia para os adultos em relação as famílias.

Uma hipótese possível para explicar o ocorrido em C. speciosa, é que a população adulta representa uma amostragem de árvores originadas de diversos ciclos reprodutivos, sendo que a heterogeneidade de gerações caracteriza a população em equilíbrio de panmixia. Em contraste, as famílias representam a amostra de 1 evento reprodutivo acontecido em 1991, de indivíduos jovens que ainda não sofrem efeito da seleção natural.

Portanto, a tendência de a população adulta estar mais próxima do E.H.W. pode ser consequiência da seleção em favor de heterozigotos, eliminando o efeito de endogamia observado nas progênies.

\subsubsection{Taxa de Cruzamento}

Conforme mostra a tabela 5, a estimativa da taxa de cruzamento uniloco média $\left(t_{s}\right)$ de 0,768 e a taxa de cruzamento multiloco média $\left(t_{m}\right)$ de 0,881 , sugerindo a ocorrência de endogamia no evento reprodutivo estudado (ano de 1991). 
Tabela 5. Estimativas da taxa de cruzamento multiloco $\left(\mathrm{t}_{\mathrm{m}}\right)$ para cada família, média referente a 26 famílias e taxa de cruzamento uniloco média ( $\mathrm{t}_{\mathrm{s}}$ ) para uma população natural de $C$. speciosa situada na Reserva Estadual de Bauru. O valor entra parênteses corresponde ao desvio padrão da média.

\begin{tabular}{cccc}
\hline Tamilia & $\mathbf{t}_{\mathbf{m}}$ & Família & $\mathbf{t}_{\mathbf{m}}$ \\
\hline 1 & $1,05(0,50)$ & 14 & $1,27(0,35)$ \\
2 & $1,08(0,46)$ & 15 & $1,06(0,44)$ \\
3 & $1,37(0,30)$ & 16 & $0,92(0,54)$ \\
4 & $1,07(0,44)$ & 17 & $1,80(0,30)$ \\
5 & $1,58(0,34)$ & 18 & $1,09(0,47)$ \\
6 & $1,13(0,30)$ & 19 & $1,21(0,41)$ \\
7 & $1,46(0,50)$ & 20 & $1,33(0,51)$ \\
8 & $0,56(0,30)$ & 21 & $0,79(0,79)$ \\
9 & $0,93(0,50)$ & 22 & $1,15(0,26)$ \\
10 & $1,45(0,37)$ & 23 & $1,14(0,39)$ \\
11 & $0,88(0,49)$ & 24 & $0,78(0,29)$ \\
12 & $1,51(0,35)$ & 25 & $0,54(0,40)$ \\
13 & $1,27(0,35)$ & 26 & $0,86(0,44)$ \\
\hline $\mathrm{t}_{\mathrm{m}}$ & $0,881(0,036)$ & & \\
\hline $\mathrm{t}_{\mathrm{s}}$ & $0,768(0,048)$ & & \\
\hline $\mathrm{t}_{\mathrm{m}}-\mathrm{t}_{\mathrm{s}}$ & $0,113(0,027)$ & & \\
\hline
\end{tabular}

A comparação entre a taxa de cruzamento multiloco e uniloco média possibilita a caracterização de cruzamentos entre aparentados e autofecundação, conforme discutem Ritland \& El-Kassaby (1985). A taxa de cruzamento entre indivíduos aparentados foi 0,113 (tm - ts) e a taxa de autofecundação foi 0,232 (1 - $\left.\mathrm{t}_{\mathrm{m}}\right)$.

As Bombacaceas estudadas Ceiba pentandra (Murawski \& Hamrick, 1992b) e Cavanillesia platanifolia (Murawski et al, 1990) mostraram respectivamente: i) 0,689 $\left(t_{m}\right)$ e $0,659\left(t_{s}\right)$;ii) em 1987; 0,52( $\left(t_{s}\right)$ e $0,57\left(t_{m}\right)$ e em 1988, 0,44 (ts $t_{s}$ e $0,35\left(t_{m}\right)$. As duas 
espécies apresentaram muitas progênies provenientes de autofecundação e foram caracterizadas como sendo de cruzamento misto. Já na espécie Quararibea asterolepis (Murawski et al, 1990) observaram-se as taxas 0,97( $\left.\mathrm{t}_{\mathrm{s}}\right)$ e 1,008 $\left(\mathrm{t}_{\mathrm{m}}\right)$, sendo classificada como espécie totalmente alógama.

Os resultados obtidos aqui, permitem indicar que C.speciosa parece comportar-se como as duas primeiras Bombacaceaes citadas acima, podendo também ser caracterizada como espécie de cruzamento misto.

$\mathrm{O}$ teste de qui quadrado para verificar aderência ao modelo multilocos mostrou valores significativos para 4 locos (PGI-1, PGM-1, PER-1 e PER-2) num total de 7 locos estudados. Ritland \& El-Kassaby (1985) mencionam que os desvios deste equilíbrio não prejudicam a obtenção das estimativas e pode estar indicando a ocorrência de fatores adicionais ao processo, como por exemplo cruzamentos preferenciais. Deve-se notar que, na nova versão do programa MLRT - 1996, o autor não considera estas estimativas para proceder as análises.

\subsubsection{Estrutura Genética Espacial}

Os resultados relativos aos índices I de Moran, para o vizinho mais próximo e para conexão de Gabriel, estão na tabela 6. Observa-se que não há indicação de estruturação espacial, visto que somente o alelo 1 do sistema enzimático MDH-3 apresentou um valor significativo do indice I de Moran (0,390 e 0,261). 
Tabela 6. Coeficientes de autocorrelação espacial (índice I de Moran) de uma população natural de Chorisia speciosa, para dois métodos de pareamento de indivíduos: vizinho mais próximo ( $\left.\mathrm{I}_{\mathrm{vmp}}\right)$ e conexão de Gabriel $\left(\mathrm{I}_{\mathrm{G}}\right)$, distância média entre indivíduos pareados e número de comparações.

\begin{tabular}{cccc}
\hline Loco & Alelo & $\mathbf{I}_{\text {vmp }}$ & $\mathbf{I}_{\mathbf{G}}$ \\
\hline LAP-1 & 1 & $-0,135(0,1632)$ & $0,024(0,1090)$ \\
\hline PGI-1 & 1 & $0,049(0,1610)$ & $0,208(0,1090)$ \\
& 2 & $-0,084(0,1632)$ & $-0,088(0,1090)$ \\
& 3 & $0,082(0,1632)$ & $-0,054(0,1090)$ \\
\hline MDH-3 & 1 & $0,390(0,1632)^{*}$ & $0,261(0,1090)^{*}$ \\
\hline PER-1 & 1 & $0,128(0,1632)$ & $0,188(0,1090)$ \\
& & & \\
\hline PER-2 & 1 & $0,103(0,1632)$ & $-0,009(0,1090)$ \\
\hline PGM-1 & 1 & $0,042(0,1632)$ & $-0,089(0,1090)$ \\
& 2 & $-0,154(0,1632)$ & $-0,172(0,1090)$ \\
\hline SKDH-1 & 1 & $0,051(0,1632)$ & $-0,047(0,1090)$ \\
\hline número de & & 37 & 80 \\
comparações & & & \\
\hline
\end{tabular}

Na tabela 7 observam-se os índices I de Moran para 9 classes de distância e 6 locos analisados. Dos 81 valores encontrados, apenas 6 mostraram-se significativos (7,4\%), sendo evidente uma flutuação aleatória entre valores positivos e negativos próximos a zero. Esta tendência a zero é ratificada, conforme mostram os correlogramas (figuras 6, 7 e 8). Com exceção ao alelo 1 do sistema enzimático MDH-3 que apresenta uma flutuação de valores positivos e negativos, onde em quatro classes de distância este valor é significativamente diferente de zero. Porém, o correlograma da média (figura 8) confirma que os índices I de Moran para as diferentes classes de distância são iguais a zero. 


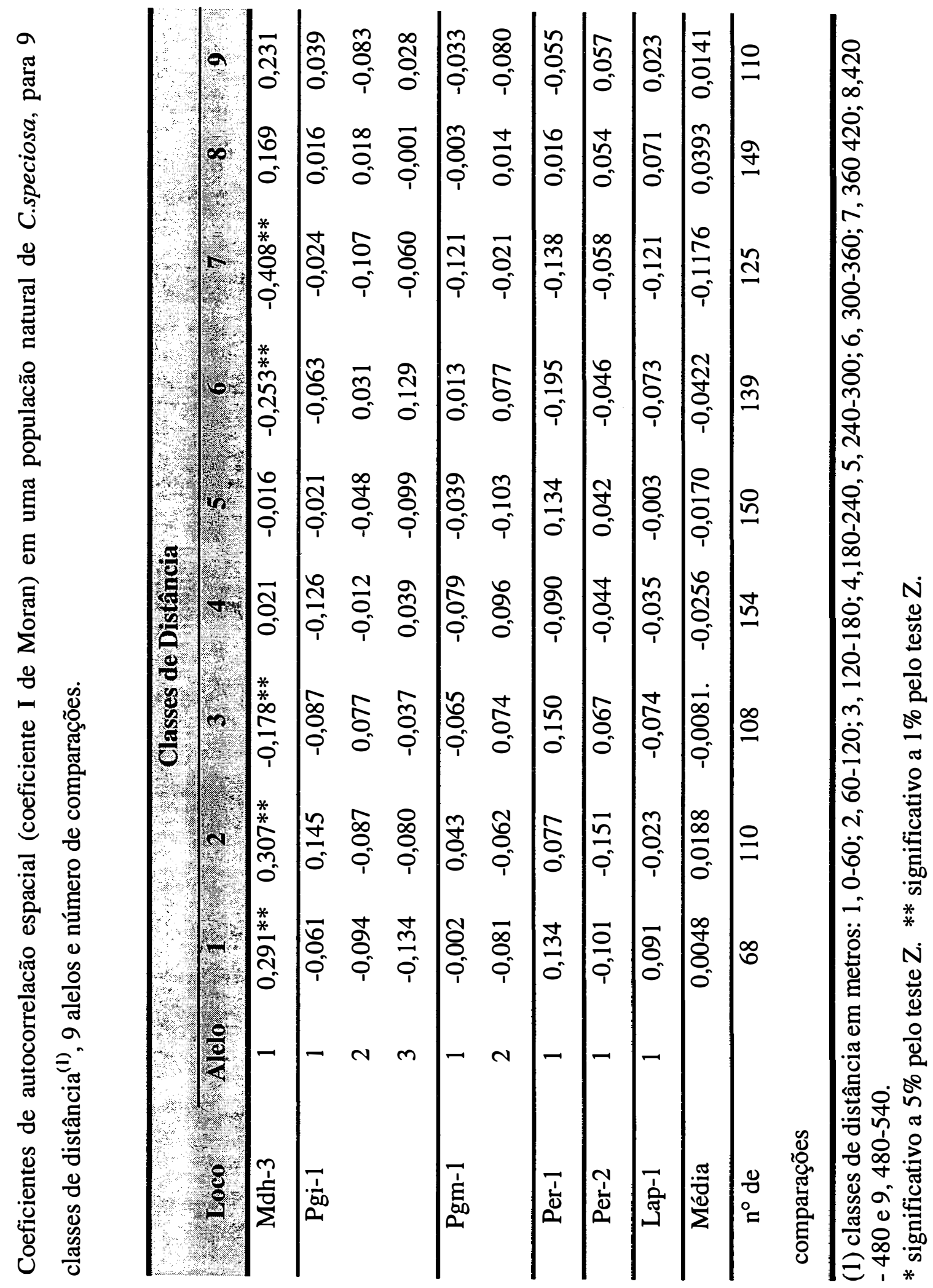

$\frac{5}{8}$ 


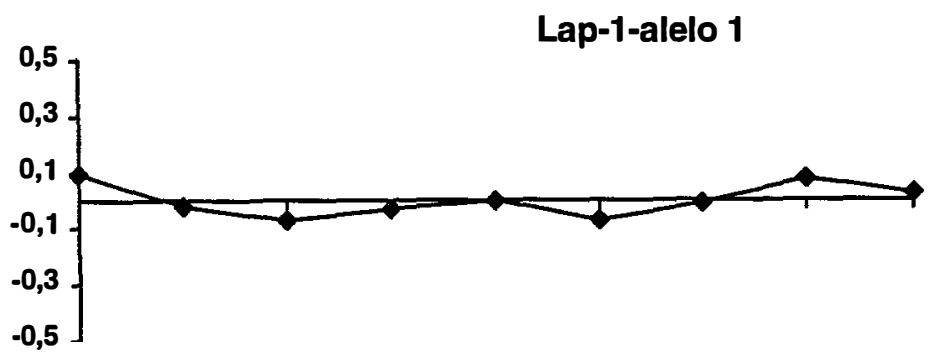

Mdh-3 alelo1

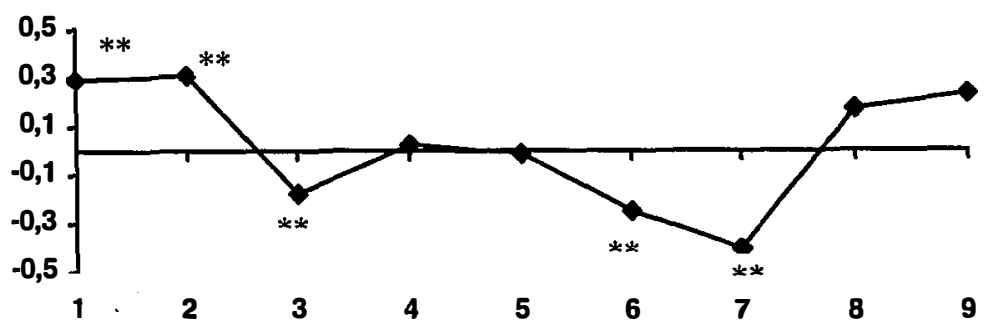

Figura 6. Correlogramas para: Lap-1 alelo 1 e Mdh-3 alelo 1, para 9 classes de distância (eixo $x$ ) e os índices I de Moran (eixo y), em uma população natural de $C$. speciosa (* significativo a $1 \% ; * *$ significativo a $5 \%$ ) 
Pgi-1 alelo 1

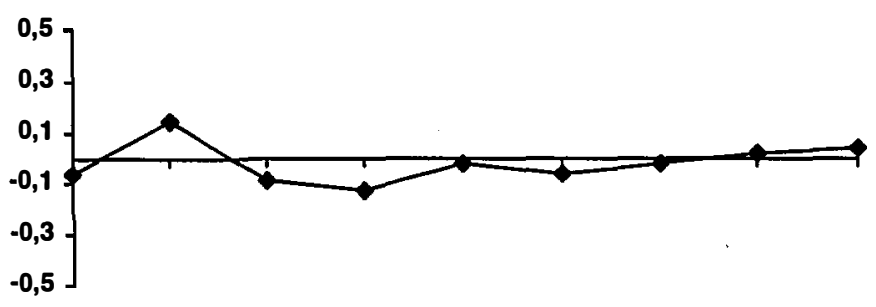

Pgi-1 alelo2

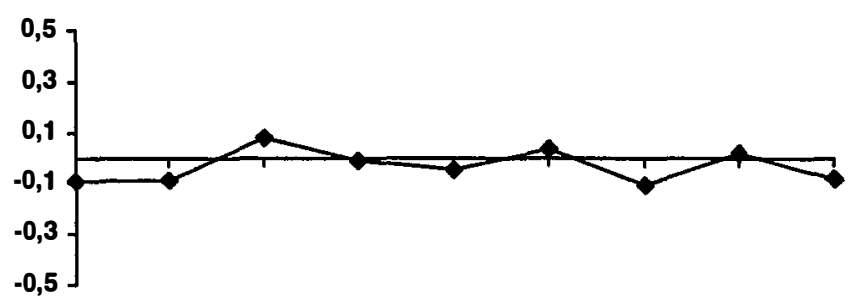

Pgi-1 alelo 3

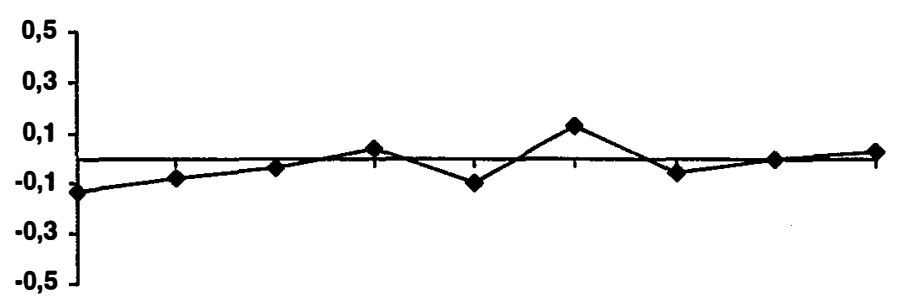

Pgm-1 alelo 1

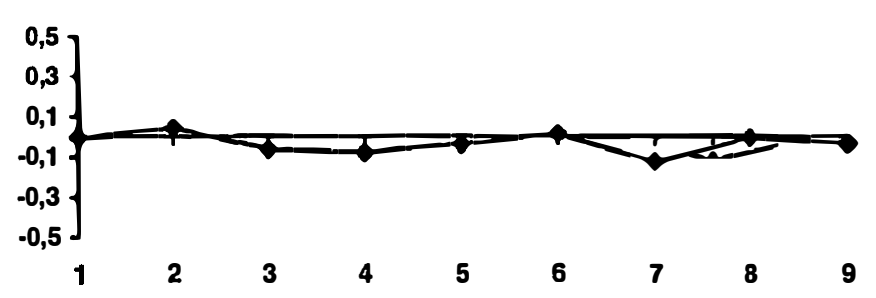

Figura 7. Correlogramas para: Pgi-1 alelo 1, Pgi-1 alelo 2, Pgi-1 alelo 3 e Pgm-1 alelo 1, para 9 classes de distância (eixo $x$ ) e índices I de Moran (eixo y), em uma população natural de $C$. speciosa. 
Pgm-1 alelo 2

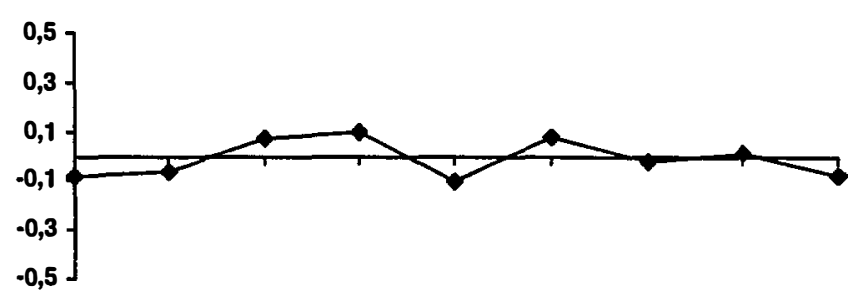

Po-1 alelo 1

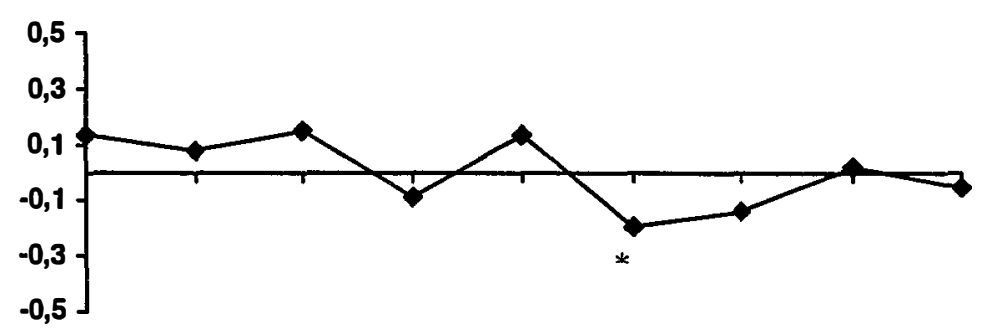

Po-2 alelo 1

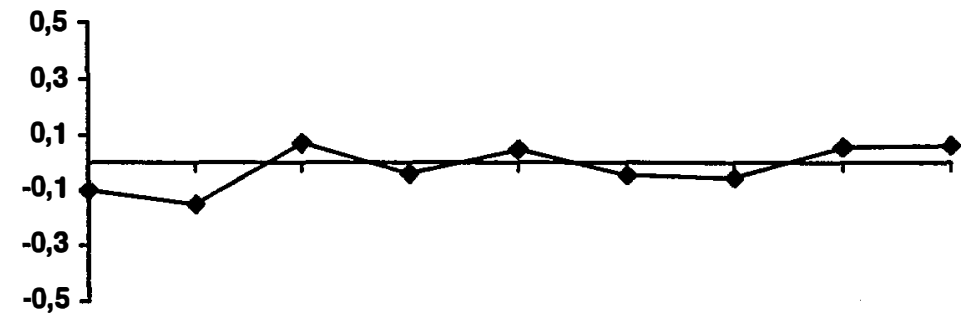

Média

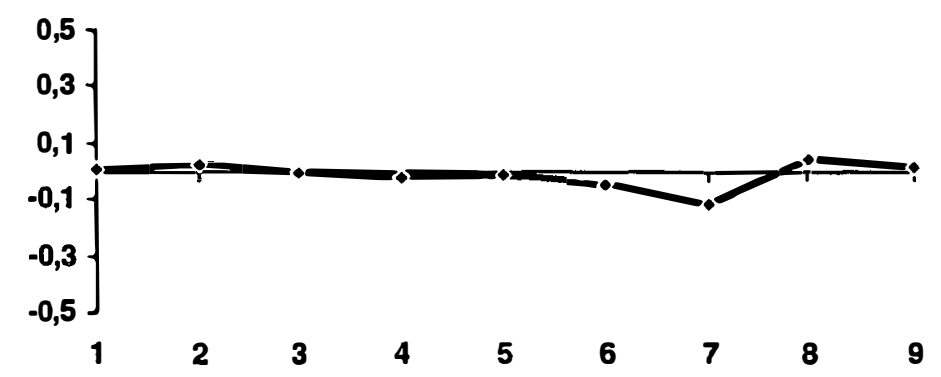

Figura 8. Correlogramas para: Pgm-1 alelo 2, Po-1 alelo 1, Po-2 alelo 1 e Média para 9 classes de distância (eixo $x$ ) e índices I de Moran (eixo $y$ ), em uma população natural de $C$. speciosa 
Analisando-se os três métodos de ponderações, os resultados sugerem que esta população não se encontra subdividí-la em agrupamentos de indivíduos relacionados geneticamente. Dentre os 9 alelos analisados, apenas um mostrou-se com significância, portanto, caso a estrutura esteja presente, ela é fraca ou ocorre em um nível que não foi possível ser detectado por esta metodologia.

O principal fator que concorre para a não formação de estruturação espacial é o fluxo gênico intra populacional, que quando é extenso evita divergências locais nas frequiências gênicas. Em $C$. speciosa o fluxo gênico via sementes pode ser considerado longo, pois atinge distâncias da ordem de 160 m (Castillo, 1986). Além disso, esta espécie parece apresentar predação de sementes pós-dispersão pelo percevejo Dysdercus. Estes aspectos podem estar contribuindo para a distribuição aleatória dos genótipos, além do fluxo gênico via pólen poder ser longo.

O padrão obtido pelo sistema $\mathrm{MDH}-3$ (figura 6) deste sistema indica um grau leve de estruturação, de forma que as árvores mais próximas (até $120 \mathrm{~m}$ ) sejam semelhantes ou aparentadas, nas classes intermediárias (120 a 360 m) os indivíduos não têm proximidade genética ou a distribuição é aleatória $(I=0)$ e nas classes mais distantes (> $420 \mathrm{~m}$ ) é possível se encontrar indivíduos mais semelhantes geneticamente. Porém tal conclusão exige cautela, pois a maioria dos alelos não demonstra isto e o resultado do sistema enzimático MDH-3 pode estar refletindo algum desvio na amostragem.

Para as espécies tropicais existem poucos dados sobre estrutura genética espacial. As populações adultas das espécies arbóreas Psychotria nervosa (Dewey \& Heywood, 1988), Platypodium elegans (Hamrick et al, 1993), Cedrela fissilis (Gandara, 1996) também apresentaram ausência de estrutura genética espacial.

Hamrick et al (1993) afirmam que somente nas espécies cuja dispersão de sementes é restrita e forma agregados de plântulas e geralmente a dispersão é por animais, como por exemplo morcego, tal qual Piper sp, é que pode haver forte estruturação espacial. 


\subsection{Estrutura Genética em Populações Fragmentadas}

\subsubsection{Estrutura Genética de Subpopulações Artificiais Originadas da Estação Ecológica de Bauru (Reserva)}

Os resultados destas análises sugerem as possíveis conseqüências genéticas, caso a população da Reserva fosse submetida a um efeito de fundador.

A tabela 8 mostra os índices de diversidade genética estimados para cada categoria de fragmentação.

Tabela 8. Índices de diversidade genética de subpopulações (Sp) criadas artificialmente pela simulação de fragmentação da população da Reserva em 3 categorias: Fr-25\%: permanência de 25\% das árvores no local (4 repetições: Sp-1, Sp-2 Sp-3 e Sp-4); Fr-50\%, permanência de 50\% de árvores no local (2 repetições: $\mathrm{Sp}-5$ e $\mathrm{Sp}-6)$; $\mathrm{Cs} \geq \mathbf{6 0}(\mathrm{Sp}-7)$, corte seletivo das árvores com DAP igual ou superior a $60 \mathrm{~cm}$ e PO, permanência de todas as árvores da população original situada na Reserva. Os valores entre parentes são os desvios padrões.

\begin{tabular}{|c|c|c|c|c|c|c|c|c|}
\hline \multirow{2}{*}{ कर } & \multirow[b]{2}{*}{ PO } & \multirow{2}{*}{$\frac{}{4} \mathrm{Sp}-1$} & \multicolumn{2}{|c|}{ Fr-25\% } & \multirow{2}{*}{$\frac{6-6}{\operatorname{Sp}=4}$} & \multicolumn{2}{|c|}{ Tr $50 \%$} & \multirow{2}{*}{ 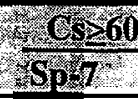 } \\
\hline & & & $S p=2$ & $\mathrm{Sp}-3$ & & $\mathrm{Sp}-5$ & $\mathrm{Sp}-6$ & \\
\hline A & $\begin{array}{c}2,22 \\
(0,32) \\
\end{array}$ & $\begin{array}{c}1.78 \\
(0,32) \\
\end{array}$ & $\begin{array}{c}2.22 \\
(0,32) \\
\end{array}$ & $\begin{array}{c}2,00 \\
(0,29) \\
\end{array}$ & $\begin{array}{c}2,11 \\
(0,31)\end{array}$ & $\begin{array}{c}2,22 \\
(0,32) \\
\end{array}$ & $\begin{array}{c}2,22 \\
(0,32)\end{array}$ & $\begin{array}{c}2,11 \\
(0,31)\end{array}$ \\
\hline $\mathbf{P}$ & 77,78 & 55,56 & 77,78 & 77,78 & 77,78 & 77,78 & 77,78 & 77,78 \\
\hline $\mathrm{H}_{\mathrm{o}}$ & $\begin{array}{c}0,245 \\
(0,068) \\
\end{array}$ & $\begin{array}{c}0,226 \\
(0,103) \\
\end{array}$ & $\begin{array}{c}0,263 \\
(0,070) \\
\end{array}$ & $\begin{array}{c}0,243 \\
(0,061)\end{array}$ & $\begin{array}{c}0,240 \\
(0,079)\end{array}$ & $\begin{array}{c}0,253 \\
(0,070)\end{array}$ & $\begin{array}{c}0,248 \\
(0,066)\end{array}$ & $\begin{array}{c}0,236 \\
(0,067)\end{array}$ \\
\hline $\mathrm{H}_{\mathrm{e}}$ & $\begin{array}{c}0,284 \\
(0,074) \\
\end{array}$ & $\begin{array}{c}0,277 \\
(0,093) \\
\end{array}$ & $\begin{array}{c}0277 \\
(0,076) \\
\end{array}$ & $\begin{array}{c}0,277 \\
(0,075) \\
\end{array}$ & $\begin{array}{c}0,296 \\
(0,070)\end{array}$ & $\begin{array}{c}0,286 \\
(0,070)\end{array}$ & $\begin{array}{c}0,286 \\
(0,074)\end{array}$ & $\begin{array}{c}0,294 \\
(0,075)\end{array}$ \\
\hline $\mathbf{n}$ & 20 & 16 & 20 & 18 & 19 & 19 & 20 & 19 \\
\hline$F_{\text {is }}$ & $0,130^{\text {ns }}$ & $0,004^{\mathrm{ns}}$ & $0,181^{\mathrm{ns}}$ & $0,083^{\mathrm{ns}}$ & $0,189^{\text {ns }}$ & $0,089^{n s}$ & $0,156^{\mathrm{ns}}$ & $0,197^{\mathrm{ns}}$ \\
\hline $\mathrm{N}$ & 52 & 13 & 13 & 14 & 13 & 26 & 27 & 29 \\
\hline
\end{tabular}

$H_{o}$, heterozigosidade observada baseada em todos os locos; $H_{e}$, heterozigosidade esperada baseada em todos os locos; $\boldsymbol{P}$, porcentagem de locos polimórficos a $0,05 \% ; \boldsymbol{A}$, número médio de alelos por loco; $\boldsymbol{n}$, número total de alelos; $F$ coeficiente médio de endogamia; $N$, tamanho médio da amostra por loco. 
Em relação aos índices de diversidade, não houve diferença significativa entre os valores estimados para as diferentes subpopulações. Aparentemente, Sp-1 mostrou os menores valores de $\mathrm{A}, \mathrm{P}, \mathrm{H}_{0}$ e $\mathrm{H}_{\mathrm{e}}$, respectivamente 1,$78 ; 55,56 \% ; 0,226$ e 0,227 sugerindo que esta subpopulação deve comportar menores níveis de diversidade genética comparada as outras.

Em contraste, a subpopulação 2 (Sp-2) apresentou os maiores valores de $\mathrm{H}_{0} \mathrm{e}$ $\mathrm{H}_{\mathrm{e}}$, respectivamente: 0,$263 ; 0,321$ e manteve os 20 alelos observados na população original, sugerindo que este remanescente conservou a diversidade genética da população original.

Os coeficientes médios de endogamia $(F)$ apresentaram uma flutuação entre as diferentes categorias, porém nenhum dos valores foi significativo, o que demonstra que as subpopulações tem a mesma característica de panminia observada na PO.

Os índices de diversidade estimados para todas as subpopulações criadas, refletiram pouco as perdas genéticas, comparadas a população original.

Segundo Futuyma (1992) e Barret \& Kohn (1991), a perda efetiva de alelos concentra-se naqueles de caráter mais raro e que contribuem com pouco peso para estimar as heterozigosidades.

Maruyama \& Fuerst (1985) afirmam que as populações que sofrem restrição repentina de seu tamanho apresentam perda de alelos mais rapidamente que a perda da heterozigosidade gênica, principalmente os alelos raros.

Para melhor caracterizar as diferenças entre subpopulações, foi construída a tabela 9 , que fornece as frequiências alélicas, número de alelos perdidos e fixados para cada subpopulação. 
Tabela 9. Frequiências alélicas, número de alelos perdidos e número de alelos fixados de subpopulações criadas artificialmente e agrupadas em 3 categorias: Fr-25\%: permanência de 25\% das árvores no local (4 repetições: Sp-1, Sp-2 Sp-3 e Sp-4); Fr-50\%, permanência de 50\% de árvores no local (2 repetições: Sp-5 e Sp-6); Cs $\geq \mathbf{6 0}$ (Sp-7), corte seletivo das árvores com DAP igual ou superior a $60 \mathrm{~cm}$ e PO, permanência de todas as árvores da população original situada na Reserva.

\begin{tabular}{|c|c|c|c|c|c|c|c|c|c|}
\hline \multirow{2}{*}{ Enzima } & \multirow[b]{2}{*}{ Alelo } & \multirow[b]{2}{*}{ Po } & \multicolumn{4}{|c|}{ Dr -25\% } & \multicolumn{2}{|c|}{$\operatorname{Tr}-50 \%$} & \multirow{2}{*}{$\begin{array}{l}C_{S}>60 \\
S_{p}=7\end{array}$} \\
\hline & & & $5 \mathrm{~s}-1$ & $\mathrm{Sp} 2$ & $\mathrm{Sp}-3$ & $\mathrm{Sp}$ & $\mathrm{Sp} 5$ & S15 6 & \\
\hline \multirow[t]{2}{*}{ SKDH-1 } & 1 & 0,845 & 1,000 & 0,750 & 0,909 & 0,727 & 0,795 & 0,900 & 0,761 \\
\hline & 2 & 0,155 & - & 0,250 & 0,091 & 0,273 & 0,200 & 0,100 & 0,239 \\
\hline \multirow[t]{4}{*}{ PGI-1 } & 1 & 490 & 0,462 & 0,500 & 0,462 & 0,550 & 0,500 & 0,480 & 0,538 \\
\hline & 2 & 281 & 0,231 & 0,292 & 0,346 & 0,250 & 0,239 & 0,320 & 0,250 \\
\hline & 3 & 0,156 & 0,154 & 0,167 & 0,154 & 0,150 & 0,152 & 0,160 & 0,135 \\
\hline & 4 & 0,073 & 0,154 & 0,042 & 0,038 & 0,050 & 0,109 & 0,040 & 0,077 \\
\hline \multirow[t]{3}{*}{ PGM-1 } & 1 & 0,837 & 0,923 & 0,708 & 0,893 & 0,808 & 0,846 & 0,827 & 0,804 \\
\hline & 2 & 0,096 & 0,077 & 0,167 & 0,107 & 0,038 & 0,058 & 0,135 & 0,107 \\
\hline & 3 & 0,067 & - & 0,125 & - & 0,154 & 0,096 & 0,038 & 0,089 \\
\hline \multirow[t]{3}{*}{ MDH-3 } & 1 & 0,872 & 0,917 & 0,885 & 0,857 & 0,813 & 0,875 & 0,870 & 0,904 \\
\hline & 2 & 0,117 & 0,083 & 0,077 & 0,143 & 0,188 & 0,125 & 0,111 & 0,060 \\
\hline & 3 & 0,011 & - & 0,038 & - & - & - & 0,019 & - \\
\hline \multirow[t]{2}{*}{ PER-1 } & 1 & 0,660 & 0,538 & 0,542 & 0,731 & 0,833 & 0,740 & 0,580 & 0,635 \\
\hline & 2 & 0,340 & 0,462 & 0,458 & 0,269 & 0,167 & 0,260 & 0,420 & 0,365 \\
\hline \multirow[t]{2}{*}{ PER-2 } & 1 & 0,429 & 0,583 & 0,250 & 0,542 & 0,346 & 0,440 & 0,417 & 0,420 \\
\hline & 2 & 0,571 & 0,417 & 0,750 & 0,458 & 0,654 & 0,560 & 0,583 & 0,580 \\
\hline \multirow[t]{2}{*}{ LAP-1 } & 1 & 0,091 & & 0,125 & 0,083 & 0,100 & 0,100 & 0,083 & 0,118 \\
\hline & 2 & 0,909 & 1,000 & 0,875 & 0,917 & 0,900 & 0,900 & 0,917 & 0,882 \\
\hline $\begin{array}{l}\text { alelos } \\
\text { perdidos }\end{array}$ & & & 4 & 0 & 2 & 1 & 1 & 0 & 1 \\
\hline $\begin{array}{l}\text { locos } \\
\text { fixados }\end{array}$ & & & 2 & 0 & 0 & 0 & 0 & 0 & 0 \\
\hline
\end{tabular}


Os alelos comuns sofreram pequenas oscilações em suas frequiências entre as diferentes subpopulações. As maiores oscilações de freqüências alélicas são observadas para os alelos raros, por exemplo, alelo 2 da enzima SKDH-1, alelo 4 da enzima PGI-1, alelo 3 da enzima PGM-1. Isto indica uma maior susceptibilidade a perda destes tipos de alelos.

Foram perdidos alelos em todas as subpopulações, exceto na Sp-2 e Sp-6. Nas subpopulações: Sp-1, Sp-3 e Sp-4 perderam-se respectivamente 4, 2 e 1 alelos; na Sp-5 e Sp-7 perdeu-se 1 alelo. Os alelos perdidos pertencem invariavelmente a uma classe de alelos raros (Mdh-3, alelo 3) ou medianamente raros (Skdh-1, alelo 2).

Esta perda poderia ser entendida como significativa, quando constata-se que em uma das subpopulações houve perda de $20 \%$ dos alelos (Sp-1). Além disso, estes resultados têm por base 7 locos, considerando-se que o genoma possui milhares de locos, a perda real de alelos deve alcançar magnetudes expressivas.

A perda drástica de variação genética também pode ser evidenciada na fixação de locos. Observa-se que na Sp-1 fixaram-se 2 locos (Skdh-1 e Lap-1), além daqueles já fixados na população original (Mdh-1 e Mdh-2).

Nei et al (1975) discutem que a quantidade de perda de heterozigosidade devido ao efeito de gargalo depende não sómente do tamanho do gargalo, mas também das taxas de crescimento populacional após o gargalo, enquanto que a perda de alelos depende largamente do tamanho do gargalo. Os dados de $C$. speciosa sugerem que as maiores perdas de alelos ocorreram quando se eliminou $75 \%$ da população.

$\mathrm{Na}$ tabela 10 apresentam-se as estatísticas $F$ de Wright, evidenciando a variação intrapopulacional $\left(F_{i s}\right)$, interpopulacional $\left(F_{s t}\right)$ e total $\left(F_{i t}\right)$ para as 2 categorias de simulação de fragmentação: $\mathrm{Fr}-25 \%$ e $\mathrm{Fr}-50 \%$. 
Tabela 10. Estatísticas $F$ de Wright para cada loco e a média de uma população natrual de $C$. speciosa, referente as categorias de fragmentação Fr-25\% e Fr-50\%, onde $F_{\text {is }}$ é o coeficiente de endogamia médio dentro de cada subpopulação, $F_{s t}$ é a divergência genética entre populações e $F_{i t}$ é o coeficiente de endogamia total para espécie:

\begin{tabular}{|c|c|c|c|c|c|c|}
\hline \multirow{2}{*}{ Locos } & \multicolumn{3}{|c|}{ Fi-25\% } & \multicolumn{3}{|c|}{ Tr-50\% } \\
\hline & $F_{i s}$ & $F_{i t}$ & $F_{s t}$ & $F_{i s}$ & $F^{2} F_{i t}$ & $y$ \\
\hline SKDH-1 & $-0,096^{\mathrm{ns}}$ & $0,011^{\text {ns }}$ & $0,098^{* *}$ & $-0,025^{\text {ns }}$ & $-0,004^{\text {ns }}$ & $0,021^{\text {ns }}$ \\
\hline PGI-1 & $-0,028^{\mathrm{ns}}$ & $-0,019^{n s}$ & $0,009^{n s}$ & $-0,120^{\text {ns }}$ & $-0,027^{\mathrm{ns}}$ & $0,004^{\mathrm{ns}}$ \\
\hline PGM-1 & $0,074^{\mathrm{ns}}$ & $0,119^{\text {ns }}$ & $0,048^{\mathrm{ns}}$ & $0,120^{\mathrm{ns}}$ & $0,127^{\text {ns }}$ & $0,008^{\mathrm{ns}}$ \\
\hline MDH-3 & $-0,160^{\text {ns }}$ & $-0,141^{n s}$ & $0,016^{\mathrm{ns}}$ & $-0,135^{\text {ns }}$ & $-0,135^{\mathrm{ns}}$ & $0,001^{\mathrm{ns}}$ \\
\hline PER-1 & $0,141^{\mathrm{ns}}$ & $0,203^{\mathrm{ns}}$ & $0,071^{\mathrm{ns}}$ & $0,174^{\mathrm{ns}}$ & $0,198^{\text {ns }}$ & $0,029^{\text {ns }}$ \\
\hline PER-2 & $0,366^{* *}$ & $0,415^{* *}$ & $0,077^{*}$ & $0,418^{* *}$ & $0,418^{* *}$ & $0,001^{\text {ns }}$ \\
\hline LAP-1 & $0,245^{\mathrm{ns}}$ & $0,268^{\mathrm{ns}}$ & $0,031^{\mathrm{ns}}$ & $0,299^{*}$ & $0,299^{*}$ & $0,001^{\text {ns }}$ \\
\hline MÉDIA & $0,085^{\text {ns }}$ & $0,129^{\text {ns }}$ & $0,049^{\text {ns }}$ & $0,123^{\text {ns }}$ & $0,131^{\text {ns }}$ & $0,010^{\text {ns }}$ \\
\hline
\end{tabular}

Os resultados de $F_{i t}$ confirmam o valor do coeficiente de endogamia $(F)$ da espécie em torno de 0,130 , as diferenças encontradas devem-se às aproximações intrínsecas no cálculo de cada categoria.

A subdivisão provocou uma diferença pequena entre as subpopulações para as 2 categorias de fragmentação $\left(F_{s t}\right)$, sugerindo a ocorrência de fluxo gênico contínuo na área amostrada o que colabora para a identidade das subpopulações.

Existe análise confirma os resultados obtidos na análise de autocorrelação espacial, mostrando que esta população não apresenta estruturação espacial. 


\subsubsection{Estrutura Genética em Fragmentos Florestais de Diferentes Tamanhos e Níveis de Perturbação}

Neste item serão apresentados os resultados relativos aos parâmetros genéticos de 4 populações naturais de $C$. speciosa situada nos fragmentos florestais: Reserva, Santa, Laranja e Shangrilá, sendo que o primeiro representa o fragmento grande e não perturbado e os demais são pequenos e perturbados. Inclui-se para comparação, uma quinta categoria de análise, onde estão agrupados todos os fragmentos formando uma única população que será chamada de megapopulação (megapop).

\subsubsection{Amostragem de campo e genética}

A amostragem na Reserva foi representada por 53 árvores adultas e nos fragmentos pequenos consistiu em (figura 3):

1. Fazenda Santa Terezinha (Santa): 15 árvores, sendo 5 jovens e 10 adultos

2. Fazenda Laranja Azeda (Laranja): 12 árvores, sendo 5 jovens e 7 adultos

3. Fazenda Shangrilá (Shangrilá): 10 árvores, sendo 3 jovens e 7 adultos

Os adultos nos fragmentos pequenos tiveram DAP, variando entre 38 a 120 cm e os indivíduos jovens tiveram DAP, variando de 10 a $28 \mathrm{~cm}$ e a altura média de $2 \mathrm{~m}$.

Em relação à amostragem genética, foram estudados 8 locos isoenzimáticos, sendo 2 monomórficos (MDH-2 e MDH-1) e 6 polimórficos (PGI-1, PGM-1, PER-2, PER-1, MDH-3, SKD-1). Com exceção da enzima LAP, todas as enzimas reveladas para amostra da população da Reserva o foram também nas outras populações. 


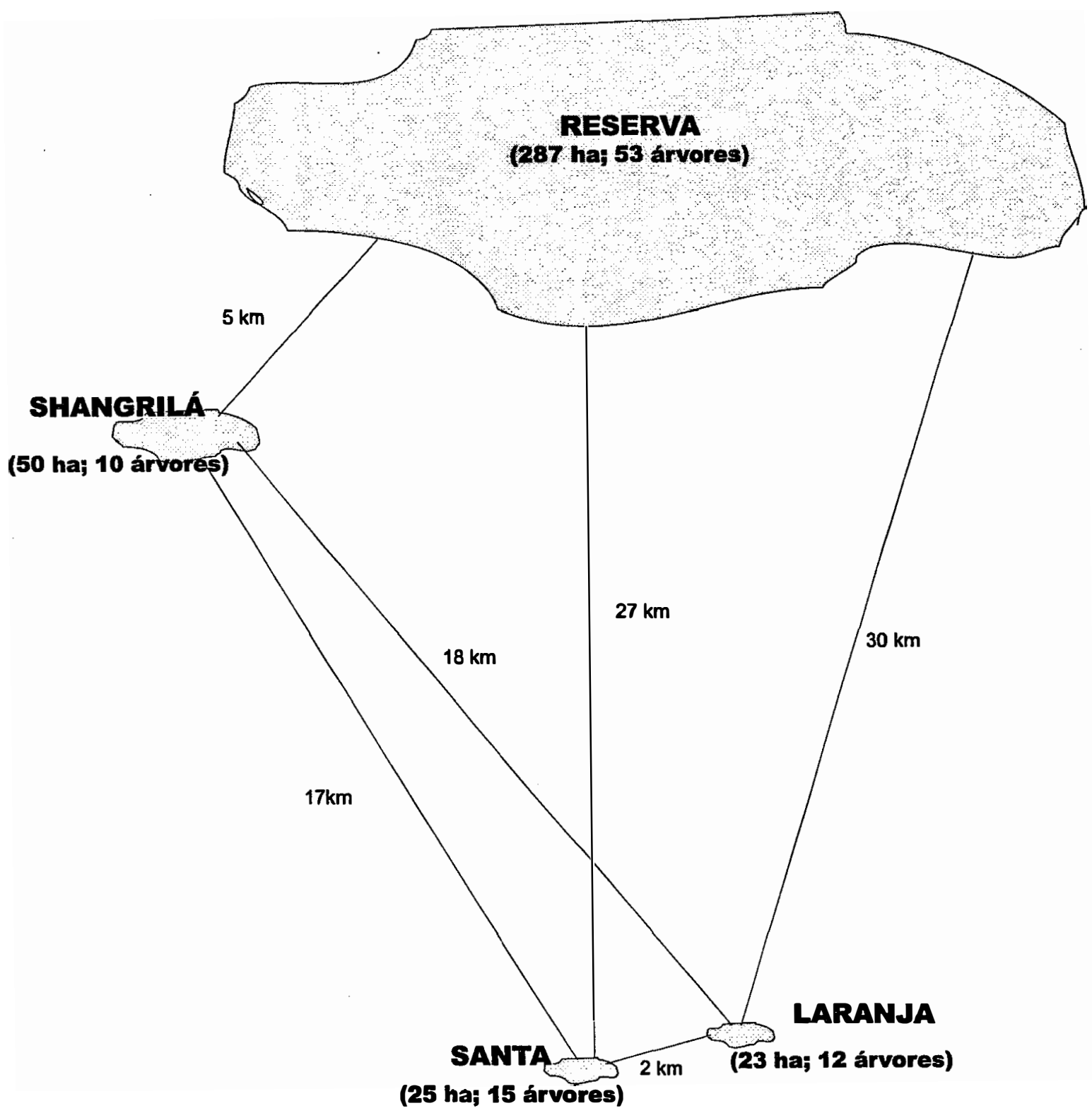

Figura 9. Esquema dos fragmentos amostrados, com suas respectivas áreas, distâncias entre fragmentos e número de indivíduos. 


\subsubsection{Diversidade genética}

A tabela 11 mostra as estimativas das freqüências alélicas e os índices de diversidade para cada população e para a megapopulação.

Tabela 11. Estimativas das frequiências alélicas e índices de diversidade genética de 4 populações naturais de $C$. speciosa procedentes de fragmentos florestais situados na região de Bauru/SP, obtidos através da análise de 8 locos alozímicos. Os valores entre parênteses são os desvios padrões.

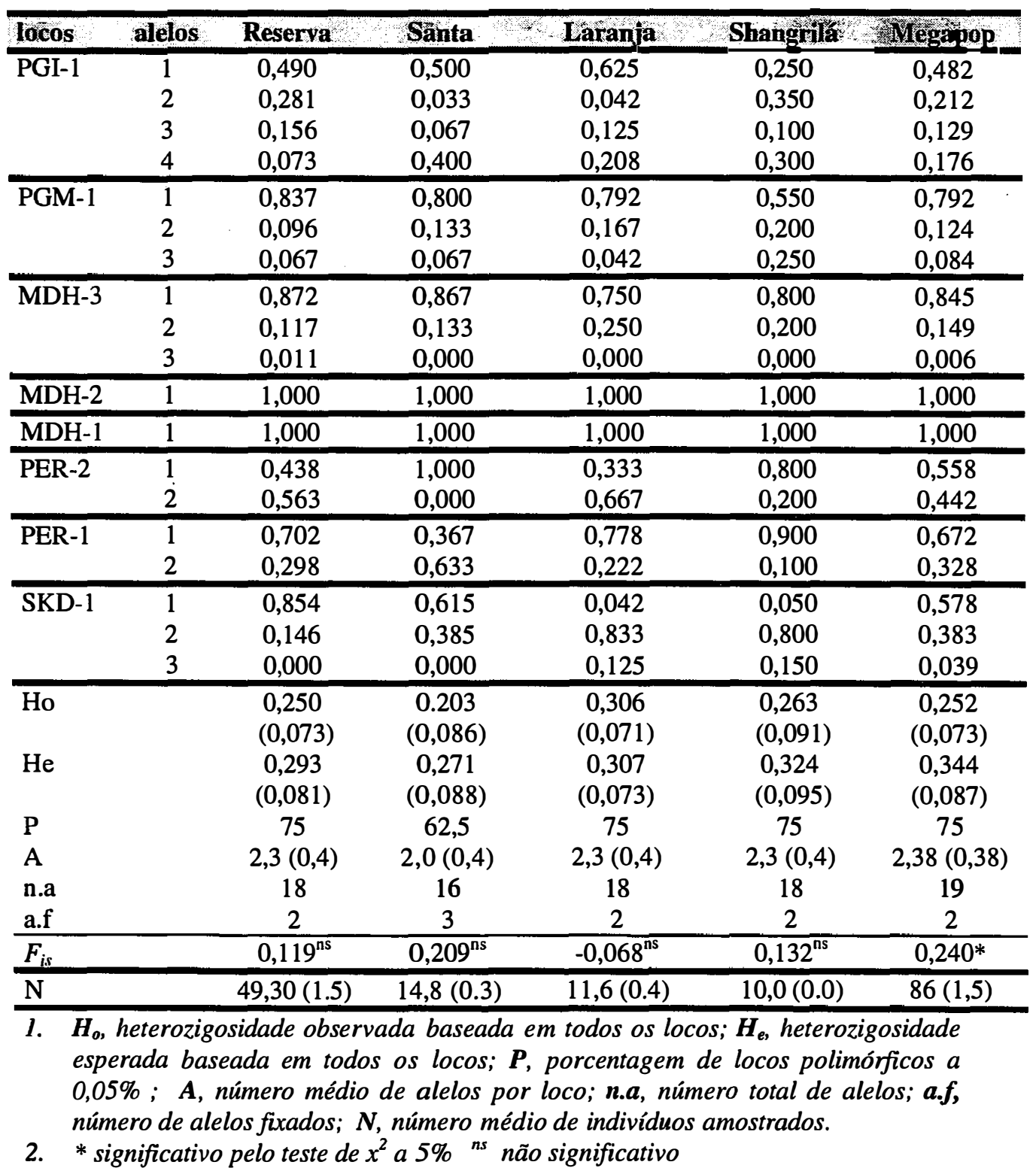


Em relação às freqüências alélicas, foi observada uma divergência na proporção de alelos interpopulações, sendo que estas diferenças são percebidas, tanto para alelos raros quanto para os comuns. Por exemplo, i) o alelo 4 do sistema PGI-1 é raro na Reserva $(0,073)$ e freqüente nos 3 fragmentos (Santa=0,400; Laranja=0,208; Shangrilá=0,300); ii) o alelo 3 do sistema PGM-1 é raro nas populações da Reserva, Santa e Laranja (respectivamente 0,067; 0,067 e 0,042) e tem freqüência alta na população de Shangrilá $(0,250)$; iii) o alelo 1 do sistema SKDH-1 é freqüente nas populações Reserva e Santa (respectivamente 0,854 e 0,615 ) e muito raro nas populações Laranja e Shangrilá $(0,042$ e 0,050).

No item 6.2.1., quando analisaram-se gargalo potencial em subpopulações artificias, as variações foram observadas somente em alelos raros, aqui na flutuação de freqüências é mais aleatória e engloba qualquer classe de alelos.

Existem exemplos, onde o alelo desaparece de uma população para outra, como é o caso do alelo 3 do sistema $\mathrm{MDH}-3$, que possui caráter muito raro na população da Reserva $(0,011)$ e desaparece nos 3 fragmentos observados. Já o alelo 3 do sistema SKD-1 aparece com freqüências não tão baixas nos fragmentos Laranja e Shangrilá (respectivamente 0,125 e 0,150 ) e não foi detectado nas demais populações.

Ocorreu a fixação de um loco do sistema PER-2, na população Santa, sendo que o alelo fixado apresentou nas populações Reserva, Laranja proporções médias $(0,438$ e 0,333$)$ e alta no fragmento Shangrilá $(0,800)$.

Portanto, analisando-se as distribuições alélicas, evidenciam-se os seguintes fenômenos: oscilações aleatórias nas freqüências, perda e fixação de alelos.

Futuyma (1992) define a deriva genética como uma flutuação aleatória das freqüências alélicas que tem como consequiência a perda e/ou a fixação de alelos, sendo este processo decorrente de uma população finita e sua intensidade inversamente proporcional ao tamanho populacional. $\mathrm{O}$ autor ressalta que as maiores probabilidades de perda são inerentes aos alelos raros ou de baixa freqüência e os alelos comuns possuem maior probabilidade de serem fixados. Os dados observados sugerem a ocorrência de deriva genética em conseqüência de uma redução populacional drástica no passado. 
Em relação aos índices de diversidade $\left(\mathrm{H}_{0}, \mathrm{H}_{\mathrm{e}}, \mathrm{P}\right.$ e A) constantes da tabela 9, observa-se que não houve diferenças significativas entre as populações. Comparando-se as estimativas obtidas para a megapopulação com os 4 fragmentos, observa-se que não há perda significativa de heterozigosidades médias $\left(\mathrm{H}_{\mathrm{o}}\right.$ e $\left.\mathrm{H}_{\mathrm{e}}\right)$. Estas podem ser consideradas como valores altos quando comparados a outras espécies tropicais. Tomando como referência os estudos de Hamrick \& Godt (1990) que compilaram estudos alozímicos incluindo 459 vegetais e concluem que em média $50,5 \%$ dos locos são polimórficos e a heterozigosidade média é 0,149 .

Isto mostra que apesar do tamanho reduzido, os fragmentos Laranja, Santa e Shangrilá ainda conservam altos índices de diversidade, que pode estar sendo mantido pela ocorrência de fluxo gênico de outros locais, pois nenhum dos fragmentos está totalmente isolado, conforme esclarecido no item Material e Métodos, os fragmentos encontram-se próximos a outras áreas fragmentadas.

Não obstante as não significâncias, aparentemente o fragmento Santa tende a apresentar os menores valores relativos a $\mathrm{H}_{\mathrm{o}}(0,203), \mathrm{H}_{\mathrm{e}}(0,271)$ e $\mathrm{P}(62,5 \%)$, sendo que ocorreu a fixação de 1 alelo, além daqueles já fixados nos locos MDH-1 e MDH-2 e ocorreu um menor número total de alelos (16 alelos), sugerindo que nesta população detem-se menores níveis de variação genética. Em contraste, a população do fragmento Laranja parece conter maior variação genética.

Inicialmente é mais fácil detectar perda e fixação de alelos, pois estes são mais severamente relacionados com diminuição populacional, a da heterozigosidade é percebida quando se dá um número maior de gerações após a fragmentação (Futuyma,1992). No caso de $C$. speciosa, ocorre que a fragmentação se deu há 50 anos e provavelmente as populações remanescentes estejam representando 1 ou 2 gerações pósfragmentação, talvez isto explique as heterozigosidades se manterem altas ainda.

Considerando o longo tempo de geração das árvores, o número de índivíduos nos fragmentos deve corresponder a um baixíssimo tamanho efetivo, já que em poucas gerações foi possível quantificar a perda genética em termos de distribuição alélica. 
Além disso, quando ocorre redução populacional, mesmo o número de alelos sendo reduzido, o grau de heterozigosidade e a variância genética podem permanecer tão altas quanto a população fonte (megapopulação), e isto é devido aos alelos raros, que possuem maior probabilidade de serem perdidos e contribuem pouco para o nível de heterozigosidade (Futuyma, 1992). Tal predição, foi observada em C. speciosa conforme mostra a tabela 8.

As poucas evidências de perda de heterozigosidade também podem estar relacionadas ao modelo de amostragem feita, já que representa mescla de árvores originadas antes e depois da fragmentação ou seja uma parte amostra a variação que já existia e sofreu um efeito de gargalo. Possivelmente se tivessem sido feitas amostragens de progênies nos fragmentos pequenos ou analisado jovens e adultos separadamente, os resultados de perda de heterozigosidade ficassem mais evidentes.

$O$ índice de fixação $\left(F_{i s}\right)$ obtido para os fragmentos Reserva, Santa, Laranja e Shangrilá não foram significativamente diferentes de zero, sugerindo que estas populações estão em EHW. Mas o índice de fixação da megapopulação foi significativo e positivo $(0,240)$, apontando para uma tendência fraca à homozigose na megapopulação (tabela 11).

Qualquer população de tamanho finito torna-se mais endogâmica com o tempo, reduzindo a proporção de heterozigotos. Neste caso, o endocruzamento faz com que as frequiências gênicas permaneçam as mesmas, mas os genótipos homozigotos têm sua freqüência aumentada. Quando a perda da variação é meramente conseqüência da redução do tamanho populacional, a população permanece em EHW (Futuyma,1992). A amostragem feita praticamente não detectou o excesso de homozigotos, que possivelmente seria observado mais claramente amostrando-se progênies nos fragmentos.

A tabela 12 mostra as estimativas de $\mathrm{P}$ relativas às probabilidades exatas de Fisher para averiguar os desvios do EHW.

Observa-se que no fragmento Reserva $84 \%$ dos locos estão em EHW, no fragmento Santa, Laranja e Shangrilá, respectivamente $40 \%, 100 \%$ e $67 \%$ estão em 
EHW. Quando se analisa uma só população (megapop) apenas 30\% dos locos estão em EHW; este valor pode ser entendido pela não ocorrência de fluxo gênico entre as populações, ou seja elas estão isoladas umas das outras. Mais uma vez, o fragmento Santa se distingue, pois aqui ele apresenta a maioria dos locos com desvios do EHW, sugerindo tendência à homozigose, conforme visto através do $F_{i s}$. Quando a população é finita, mas os cruzamentos são aleatórios, têm-se a manutenção do EHW e da proporção de heterozigotos (Crow \& Kimura, 1970)

Tabela 12. Probabilidades relativas ao teste exato de Fisher (Valores de P) para verificar os desvios do equilíbrio de Hardy-Weinberg, em 4 populações naturais de $C$. speciosa procedentes de fragmentos florestais na região de Bauru/SP, obtidos através da análise de 6 locos alozímicos

\begin{tabular}{cccccc}
\hline locos & Reserva & Santa & Laranja & Shangrila & Megapop \\
\hline PGI-1 & $1,000^{\text {ns }}$ & $0,628^{\text {ns }}$ & $0,199^{\text {ns }}$ & $1,035^{\text {ns }}$ & $1,000^{\text {ns }}$ \\
PGM-1 & $0,604^{\text {ns }}$ & $\left.0,055^{*}\right)$ & $0,373^{\text {ns }}$ & $0,015^{*}$ & $0,002^{* *}$ \\
MDH-3 & $1,000^{\text {ns }}$ & $1,000^{\text {ns }}$ & $0,529^{\text {ns }}$ & $1,000^{\text {ns }}$ & $0,201^{\text {ns }}$ \\
PRX-2 & $0,007^{* *}$ & - & $0,518^{\text {ns }}$ & $0,009^{* *}$ & $0,000^{* *}$ \\
PRX-1 & $0,205^{\text {ns }}$ & $0,033^{*}$ & $1,000^{\text {ns }}$ & $1,000^{\text {ns }}$ & $0,002^{* *}$ \\
SKD-1 & $1,000^{\text {ns }}$ & $0,019^{* *}$ & $1,000^{\text {ns }}$ & $1,000^{\text {ns }}$ & $0,000^{* *}$ \\
\hline
\end{tabular}

* significativo a 5\%; ** significativo a $1 \% ;{ }^{n . s}$ não significativo

Na tabela 13 evidenciam-se as estatísticas $\mathrm{F}$ de Wright das 4 populações. 
Tabela 13. Estatísticas $F$ de Wright para cada loco e a média dos locos, referentes a 4 populações naturais de C.speciosa, procedentes de fragmentos florestais na região de Bauru/SP, obtidos pela análise de 6 locos alozímicos:

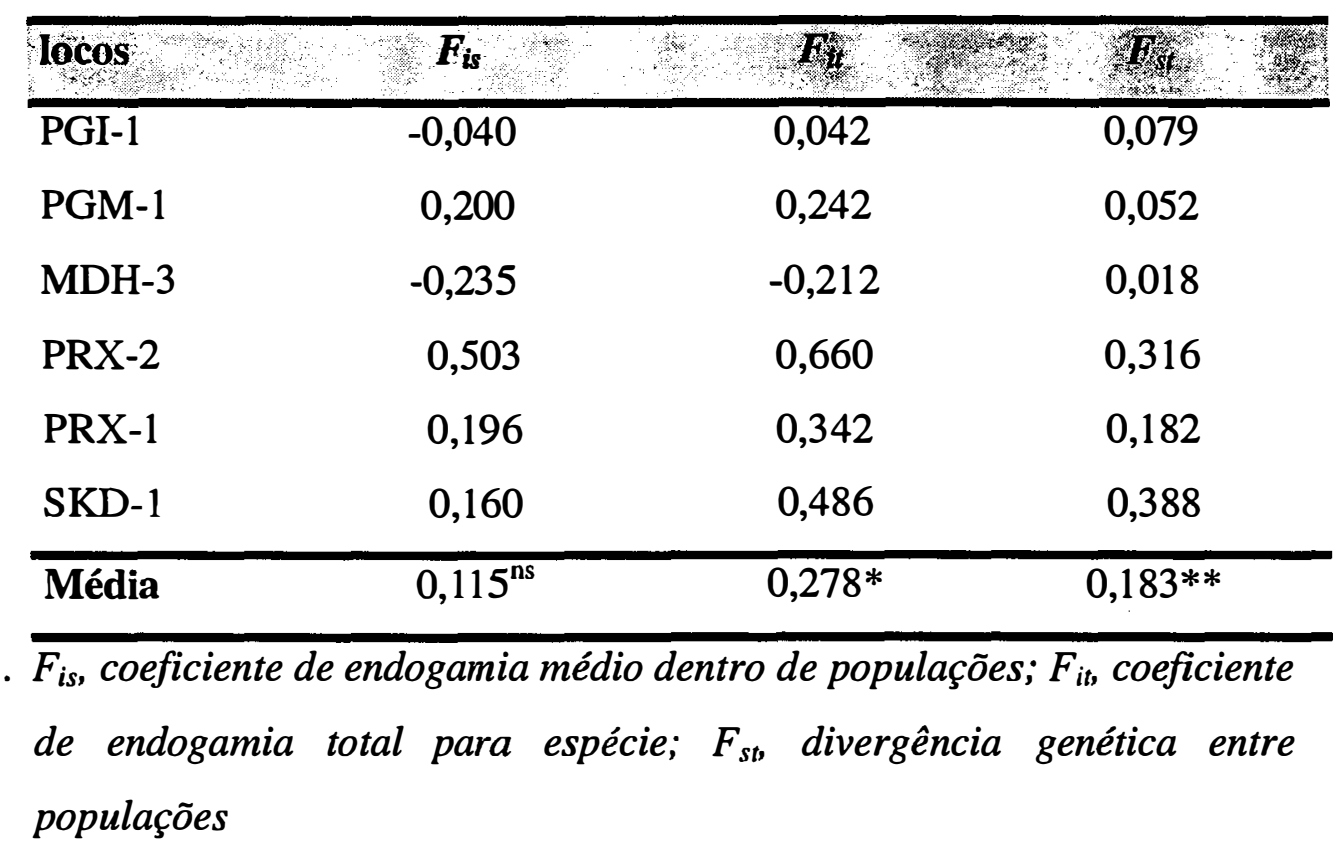

As estimativas $F_{i t}$ e $F_{s t}$ foram significativamente diferentes de zero, o que confirma os níveis de endogamia alto para a espécie (observados pelo $F_{i s}$ das progênies: 0, 239) e uma alta divergência genética entre populações.

Reis (1996), estudou 8 populações de Euterpe edulis situadas em locais distintos e distantes da Floresta Atlântica, dos Estados de Santa Catarina e São Paulo e encontrou valores baixos de $F_{s t}$ (0,031 para adultos e 0,026 para progênies). Hamrick \& Murawski (1991) estudando populações separadas $5 \mathrm{~km}$ uma das outras, concluem que as taxas de cruzamento elevado produz uma uniformidade às populações, ocasionando baixos graus de diferenciação inter-populacional.

Em contraste, Chase et al (1995) estudando populações de Cordia alliodora distantes $1,1 \mathrm{~km}$ encontraram $F_{s t}$ de 0,117 . Murawski \& Bawa (1994) encontraram os valores de $F_{s t}$ para populações de Stemonoprous oblongifolius e Shorea trapezifolia 
respectivamente 0,163 e 0,111, em populações distantes de 10 a $44 \mathrm{~km}$. Hall et al (1996) encontraram para as espécies Pentaclethra macroloba e Carapa guianensis respectivamente $22 \%$ e $5 \%$ de divergência populacional. Todos estes valores são considerados altos e determinam a divergência genética entre populações.

Hall et al (1996) examinaram a diversidade genética de Pithecellobium elegans em 8 populações fragmentadas na Costa Rica e observaram menores níveis de heterozigosidade nas populações menores. Houve uma correlação positiva entre diferenciação dos fragmentos e distância da área da Reserva de La Selva. A heterozigosidade média encontrada foi 0,13 com $35 \%$ de polimorfismo, o $F_{s t}$ entre fragmentos foi 0,101 representando alta divergência interpopulacional . Os autores concluem que as populações pequenas e isoladas não persistirão com o tempo e que os fragmentos situados no entorno da Reserva de La Selva possuem importante valor genético.

Foré et al (1992) estudaram a estrutura genética após a fragmentação em 15 populações de Acer saccharum e relacionaram isolamento dos fragmentos com níveis de diversidade genética. Os autores concluem que a diversidade genética não diferiu entre árvores e indivíduos jovens em todos os locais, a diferença genética entre fragmentos foi mais significativa $\left(\mathrm{G}_{\mathrm{st}}=3 \%\right)$ para as árvores do que para os jovens, que o fluxo gênico foi maior após a fragmentação, possivelmente devido a maior incidência de vento e que a fragmentação neste caso não acarretou isolamento das populações.

Young et al (1993) investigaram o efeito da fragmetação na variação genética de Acer saccharum, comparando 8 populações em florestas contínuas com 8 populações em áreas fragmentadas, situadas no sul de Ottawa e oeste de Ontário (Canadá). Ao contrário das predições teóricas, os autores concluem que para esta espécie o aumento da deriva genética e da endogamia não reduz a variação genética entre indivíduos dentro de populações e entre populações, o $F_{s t}$ foi 0,017 para fragmentos e 0,019 para populações contínuas, o efeito de fundador resultou na perda de 6 alelos nos fragmentos. A manutenção da variação genética nos fragmentos se deve ao número 
limitado de gerações após a fragmentação e que a alta variação observada sugere que deve haver fluxo gênico entre os locais.

As populações estudadas de $C$. speciosa mostraram alta divergência interpopulacional $\left(F_{s t}=0,183\right)$. Este dado corrobora com a hipótese de que está havendo deriva genética nos fragmentos, que foi evidenciada também pela análise das distribuições alélicas. Entretanto, não se observou perda nos níveis de heterozigosidade. A manutenção de altos níveis de heterozigosidade pode ser explicada pela presença de fluxo gêncio intrapopulacional intensa; ou pelo curto período de fragmentação que permitiu a existência de poucas gerações pós-fragmentação, ou pela amostragem insuficiente ( não foram amostradas progênies nos fragmentos pequenos).

Não houve relação entre distância dos fragmentos e níveis de diferenciação, o que pode ser observado através da distância genética de Nei (1972), como mostra a tabela 14. As populações Santa e Laranja estão bem próximas $(2 \mathrm{~km})$ e diferem em $17,5 \%$, em segundo lugar estão as populações de Reserva e Shangrilá, que estão distantes $5 \mathrm{~km}$ e diferem em 16,4\%. A maior semelhança ficou entre as populações Shangrilá e Laranja que diferem em 7,6\% e estão a 18 km de distância.

Tabela 14. Distância genética de Nei (1972) em porcentagem, referentes a 4 populações naturais de C.speciosa, procedentes de fragmentos florestais na região de Bauru/SP, obtidas pela análise de 6 locos alozímicos:

\begin{tabular}{ccccc}
\hline População & Reserva & Santa & Laranja & Shangrilá \\
\hline Reserva & - & - & - & - \\
Santa & $10,4 \%$ & - & - & - \\
Laranja & $12,3 \%$ & $17,5 \%$ & - & - \\
Shangrilá & $16,4 \%$ & $13,5 \%$ & $7,6 \%$ & - \\
\hline
\end{tabular}




\section{CONCLUSÕES}

- A diversidade genética apresentada pelas populações de Chorisia speciosa está em torno da média das populações de espécies arbóreas tropicais já estudadas.

- A taxa de cruzamento obtida para C.speciosa sugere a ocorrência de endogamia no evento reprodutivo estudado proveniente tanto de autofecundação quanto de cruzamento entre indivíduos aparentados.

- A população de Chorisia speciosa situada na Reserva Ecológica de Bauru não apresenta estruturação genética espacial, evidenciando fluxo gênico capaz de prevenir a formação de estrutura.

- A conseqüência genética da fragmentação ficou evidenciada pela potencial perda de alelos raros, detectada quando se analisou efeito de fundador, criado artificialmente na população da Reserva Ecológica de Bauru; e também pela perda, fixação de alelos e oscilação aleatórias das frequiências alélicas observadas nas populações referentes os fragmentos pequenos e perturbados. Estes resultados e o alto nível de divergência genética encontrado para as quatro populações, $\left(F_{s t}=0,183\right)$, sugerem a ocorrência de deriva genética entre as populações estudadas de Chorisia speciosa.

- Os parâmetros que medem diversidade genética $\left(\hat{\mathrm{H}}_{0}, \hat{\mathrm{H}}_{\mathrm{e}}, \hat{\mathrm{P}}, \hat{\mathrm{A}}\right.$ e $\left.\hat{F}\right)$ não refletem a perda de alelos raros. Estes parâmetros não foram bons indicadores de perda genética entre as quatro populações estudadas. Estas perdas ficaram evidentes a partir da análise direta das frequiências alélicas.

- Mesmo o período de fragmentação sendo curto (50 anos), foi possível encontrar níveis de perda genética nas populações estudadas.

- Para ampliar a compreensão dos fenômenos de perda genética que ocorre nos fragmentos pequenos e perturbados, seria importante se trabalhar com senso demográfico ao invés de amostragem e proceder amostras separadas de indivíduos jovens (banco de plântulas da floresta ou através da coleta de sementes e obtenção de progênies) e adultos. Os jovens por serem representantes natos de eventos reprodutivos pós-fragmentação, poderiam refletir melhor as perdas genéticas, através dos parâmetros genéticos convencionais $\left(\hat{\mathrm{H}}_{\mathrm{o}}, \hat{\mathrm{H}}_{\mathrm{e}}, \hat{\mathrm{P}}, \hat{\mathrm{A}} \mathrm{e} \hat{F}\right)$. 


\section{REFERÊNCIAS BIBLIOGRÁFICAS}

ALFENAS, A.C.; PETERS, I.; BRUNE, W. \& PASSADOR, G.C. Eletroforese de proteínas e isoenzimas de fungos e essências florestais. Viçosa-MG, UFV. 1991. $242 \mathrm{p}$.

ALVAREZ-BUYLLA, E.R. \& GARAY, A.A. Population genetic structure of Cecropia obtusifolia, a tropical pioneer species. Evolution, 48(2):437-453. 1994

BALLAL, S.R.; FORÉ, S.A. \& GUITTMAN, S.I. Apparent gene flow and genetics structure of Acer saccharum subpopulations in forest fragments. Can. J. Bot. Vol. 72, 1994. 1311-15.

BARRETT, S.C.H. \& KOHN, J.R. Genetic and evolutionary consequences of small population size in plants: implications for conservation. In: FALK, D.A. \& HOLSINGER, K.E., (eds) Genetics and conservation of rare plants. Center for plant conservation. Oxford University Press, 1991. 3-30.

BAWA, K.S. \& ASHTON, P.S. Conservation of rare trees in tropical rain forests: a genetic perspective. In: HOISINGER, D. e FALK, A. (eds) Genetics and conservation of rare plants. St. Louis, MO. 62-74.

BILLINGTON, H.L. Effect of population size on genetic variation in a dioecious conifer. Conserv. Biol., 5. 115-119. 1991.

BORGES, H.B.N.; LUVIZOTTO, P.R.I.; PENTEADO, S. Biologia floral da paineira. Piracicaba, Departamento de Ciências Florestais - ESALQ, 1986. (não publicado)

BROWN, A.H.D. \& WEIR, B.S. Measuring genetic variability in plant populations. In: Tanksley, S.D. \& Orton, T.J. (eds.) Isozymes in plant genetics and breeding. Part A. Amsterdam, Elsevier. 219-239. 1983

CARVALHO, P.E.R. Espécies florestais brasileiras: recomendações silviculturais, potencialidades e uso da madeira. Colombo - PR, EMBRAPA - CNPF. 1994. 640p. 
CASTILLO, C. A. R. Dispersão anemocórica das sementes de paineira (Chorisia speciosa St. Hil.) na região de Bauru, Estado de São Paulo. Piracicaba, 1986. Mestrado- Escola Superior de Agricultura "Luiz de Queiroz" / USP.

CATARINO, L.M.E. Estudo fisionômico florístico e fitossociologia em matas residuais no município de Piracicaba/SP. Mestrado. Unicanp, 1989. 181 p.

CAVASSAN, O. Levantamento fitossociológico da vegetação arbórea da mata da Reserva Estadual de Bauru utilizando o método dos Quadrantes. Mestrado Instituto de Biociências de Rio Claro. UNESP, 1982. 102 p.

CHARLESWORTH, D. \& CHARLESWORTH, B. Inbreeding depression and its evolutionary consequences. Annu. Rev. Ecol. Syst. 1987. 18: 237-68.

CHASE, M.R.; BOSHIER, D. \& NEVO, E. Conservation implications of population genetic structure of Cordia allidora, a neotropical forest tree species. American Journal of Botany 82: 468-475. 1995.

CROW, J.P. \& KIMURA, M. 1970. An introdution to population genetics theory. Haveper and row (eds.) NY. Cap. 7.

DEWEY, S.E. \& HEYWOOD, J.S. Spatial genetic structure in a population of Psychotria nervosa. I. Distribution of genetypes. Evolution, 42: 834-838. 1988.

DURIGAN, G. Florística, fitossociologia e produção de folhedo em matas ciliares da região oeste do Estado de S. Paulo. Mestrado. Unicamp, 1994. 149 p.

ELLSTRAND, N. C. \& ELAN, D.R. Population genetic consequences of small population size: inplication for plant conservation. Annu. Rev. Ecol. Syst. 1993. 24: $217-42$.

FORÉ, S.A.; HICKEY, R.J.; VANKAT, J.L.; GUTTMAN, S.; SHAEFER, R.. Genetic structure after forest fragmentation: a landscape ecology perspective on Acer saccharum. Can. J. Bot. Vol. 70. 1992. 1659-68.

FUTUYMA, D.J. Biologia evolutiva. Ribeirão Preto, Sociedade Brasileira de Genética. $1992.631 \mathrm{p}$. 
GANDARA, F.B. Diversidade genética, taxa de cruzamento e estrutura espacial dos genótipos em uma população de Cedrela fissilis Vell. (Meliaceae). Piracicaba, 1996, 96 p. (Mestrado-ESALQ/USP).

GIBBS, P.E. \& BIANCHI, M. Post-pollination Events in species of Chorisia speciosa (Bombacaceae) and Tabebuia (Bignoniaceae) with late-acting self-incompatibility. Bot. Acta 106(1993) 64-71.

GOMES, F.P. Curso de Estatística Experimental. USP/ESALQ, $13^{\text {a }}$ ed. 1990.

HALL, P.; WALKER, S. \& BAWA, K.. Effect of forest fragmentation on genetic diversity and mating system in tropical tree. Pithecellobium elegans. Conservation Biology. Vol 10 no 3. June 1996. 757-68.

HAMRICK, J. L. Plant population genetics and evolution. American Journal of Botany, 69(10) 1685-93. 1982.

HAMRICK, J.L. \& GODT, M.J.W.Allozyme diversity in plant species. In: Brown, A.H.D.; Clegg, M.T.; Kahler,A.L. \& Weir, B.S. (eds) Plant Population Genetics, Breeding, and Genetic Resources. Sinauer, Sunderland, Massachusetts: 43-63. 1990.

HAMRICK, J.L.; LINHART, Y.B.; MITTON, J.B. Relation between life history characteristics and electrophoretically detectable genetic variation in plants. Ann. Ver. Ecol. Syst., 10: 173-200. 1979.

HAMRICK, J.L. \& LOVELESS, M.D. Isozyme variation in tropical trees: procedures and preliminary results. Biotropica, 18(3):201-207. 1986.

HAMRICK, J.L.; MURAWSKI, D.A. \& NASON, J.D. The influence of seed dispersal mechanisms on the genetic structure of tropical tree populations. Vegetation, 107/108:281-297. 1993.

HUBBELL, S.P. \& FOSTER, R.B. 1986. Commonness and rarity in a neotropical forest: implications for tropical tree conservation. In: Soulé, M.E. (eds). Conservation Biology. Sinawer Ass. Publ. Sunderland. 584 p. 
HUENNEKE, L.F. Ecological Implications of genetics variation in plant population. In: FALK, D.A. \& HOLSINGER, K.E., eds., Genetics and Conservation of rare plants. Center for plant conservation. Oxford University Press. 1991. 31-44.

JANZEN, D.H. Herbivores and the number of tree species in tropical forests.. American Naturalist, 104: 501-528. 1970.

JOLY, C.A. \& CRAWFORD, R.M. Variation in tolerance and metabolic responses to flivoding in some tropical trees. Journal of Experimental Britany. 33: 135, 799809. 1982.

KAGEYAMA, P.Y. \& GANDARA, F.B. Dinâmica de populações de espécies arbóreas: implicação para o manejo e a conservação. III Simpósio de Ecosistemas da Costa Brasileira - Anais. Academia de Ciências do Estado de São Paulo. 1993.

KEPHART, S.R. Starch gel eletrophoresis of plant isozymes: a comparative analysis of techniques. American Journal of Botany, New York, 77(5): 693-712, 1990.

LEITÃO-FILHO, H.F. Consideração sobre a florística de florestas tropiciais e subtropicias do Brasil. IPEF (35), abril, 1987. 41-46.

LEPSCH-CUNHA, N. Estrutura genética e fenologia de espécies raras de Couratari spp. (Lecythidaceae) na Amazônia Central. Piracicaba, 1996. 147 p. (MestradoESALQ/USP).

LI, C.C. \& HORVITZ, D.G. Some methods of estimating the inbreeding coefficient. American Journal of Human Genetics 5:107-117. 1953.

LORENZI, H. Árvores brasileiras manual de identificação e cultivo de plantas arbóreas nativas do Brasil. Editora Plantarum. Nova Odessa, São Paulo, 1992. 352 p.

LOVELESS, M.D. \& HAMRICK, J.L. Distribución de la variación en especies de árboles tropicales. Rev. Biol. Trop., 35(supl.1):165-175. 1987.

MARUYAMA, T. \& FUERST, P.A. Population bottlenecks and nonequilibrium models in population genetics. II number of alleles in a small population that was formed by a recent bottleneck. Genetics 111: 675-689. November, 1985. 
MORAES, M.L.T. Variabilidade genética por isoenzimas e caracteres quantitativos em duas populações naturais de aroeira Myracrodruon urundeuva F.F. \& M.F. Allemão Anacardiaceae (Syn: Astronium urundeuva (Fr. Allemão) Engler. Piracicaba, 139p. 1992. (Doutorado - Escola Superior de Agricultura "Luiz de Queiroz" - USP).

MORAES, P.L.R. Estrutura genética de população de Cryptocarya moschata NEES e MARTINS Ex NEES (Lauraceae). Tese Doutorado. Rio Claro/SP 1997 (não publicado).

MORELLATO, L.P.C. Estudo da fenologia de árvores e lianas de uma floresta semidecídua no sudeste do Brasil. Campinas, 176p. 1991. (Doutorado - Instituto de Biologia - UNICAMP).

MURAWSKI, D.A. Reproductive biology and genetics of tropical trees from a canopy perspective. Manuscrito, 1995.

MURAWSKI, D.A. \& HAMRICK, J.L. Mating system and phenology of Ceiba pentandra (Bombacaceae) in Central Panama. Journal of Heredity, 83(6):401-404. 1992b.

MURAWSKI, D.A. \& BAWA, K.S. Genetic structure and mating system of stemonoporus oblongifolius (Dipterocarpaceae) in Sri Sank. American Journal of Botany 81: 155-160. 1994.

MURAWSKI, D.A. \& HAMRICK, J.L. The effect of the density of flowering individuals on the mating systems of nine tropical tree species. Heredity, 67: 167174. 1991.

MURAWSKI, D.A. \& HAMRICK, J.L. The mating system of Cavanillesia platanifolia under extremes of flowering-tree density: a test of predictions. Biotropica, 24(1):99-101. 1992a.

MURAWSKI, D.A.; HAMRICK, J.L.; HUBBELL, S.P. \& FOSTER, R.B. Mating systems of two Bombacaceous trees of a neotropical moist forest. Oecologia, 82:501-506. 1990.

- NEI, M. Analysis of gene diversity in subdivided population. Proceding National Academic Science, 70: 3321-323, 1973. 
NEI, M. Genetic distance between populations. American Naturalist. Lancaster, 106:283-92. 1972.

NEI, M. Molecular evolutionary genetics. New York, Columbia University Press, 1987. $512 \mathrm{p}$.

NEI, M. Molecular population genetics and evolution. New York, American Elsewies Pub. Co. 1975. 288p.

NEI, M.; MARUYAMA, T. \& CHAKRABORTY, R.. The Bottlenck effect and genetic variability in population. Evolution 29: 1-10. Mar. 1975.

NOGUEIRA, J.C.B. Regeneração natural de Mata Ciliar na Estação Ecológica de Bauru, 60 Congresso Florestal Brasileiro. Campos do Jordão/SP. 22 a 27 de setembro de 1990. 305-307.

O'MALLEY, D.M. \& BAWA, K.S. Mating system of a tropical rain forest tree species. American Journal of Botany, 74(8): 1143-1149. 1987.

PAGANO, S.N. Estudo florístico, fitossociológico e de ciclagem de nutrientes em mata mesófila semidecídua no município de Rio Claro/SP. Dep. de Bot. do Inst. de Biociências de Rio Claro - UNESP, 1985. 201 p.

PAIVA, J.R. Variabilidade enzimática em populações naturais de seringueira (Hevea brasiliensis (Willd ex Adr. de Juss.) Müell. Arg.). Piracicaba. 144p. 1992. (Doutorado - Escola Superior de Agricultura "Luiz de Queiroz"/USP)

PAIVA, J.R.; KAGEYAMA, P.Y.; VENCOVSKY, R. \& CONTEL, P.B. Genetics of rubber tree (Hevea brasiliensis (Willd. ex Adr. de Juss.) Müll. Arg.) I. Genetic variation in natural populations. Silvae Genetica, 43(5/6):307-312. 1994.

PIO CORRÊA, M.P. \& PENNA, S. Dicionário das plantas úteis do Brasil e das exóticas cultivadas. Volume V. 1978. Rio de Janeiro. Ministério da Agricultura. IBDF. p. 328-29.

POLANS, N.O. \& ALLARD, R.W. Na experimental evaluation of the recovery potential of ryegrass populations from genetic strees resulting from restriction of population size. Evolution, 43. 1320-1324. 1989. 
RAMALHO, R.S. Paineira- Chorisia speciosa St. Hil. Universidade Federal de Viçosa, MG, Brasil. Série Técnica - Boletim 32. 11 p. 1972.

REIS, M.S. Distribuição e dinâmica da variabilidade genética em populações naturais de palmiteiro (Euterpe edulis). 1996. 209 p. (Tese-ESALQ/USP).

RITLAND, K. Multilocus mating system program - MLTR. Version 1.1. 1996. (unpublished).

RITLAND, K. \& JAIN, S. A model for the esttimation of outcrossing rate and gene frequencies using independent loci. Heredity, 47: 35-52. 1981.

RITLAND, K. \& EL-KASSABY, Y.A. 1985. The nature of inbreeding in a seed orchard of Douglas fir as shown by na efficient multilocus model. Theocetical and Applied Genetics 71: 375-384.

RODRIGUES, R.R. Análise de vegetação natural às margens do Rio Passa Cinco, Ipeúna, SP. Biol. Vegetal/UNICAMP, Tese, 1991. 325 p.

SALGADO, A.L.B. \& CIARAMELlO, D. Produção de Frutos e de Paina de Chorisia speciosa St. Hil. B. Cient. Int. Agron. no 20. 1990. Campinas/SP. 24p.

SALIS, S.M. Composição Florística e Estrutura de um remanescente de mata ciliar do Rio Jacaré Pepira - Brotas/SP. Mestrado. Inst. de Biologia. Unicamp, 1990. 111 p.

SAUNDERS, D.A.; HOBBS, R.J. \& MARGULES, C.R. Biological consequences of ecosystem fragmentation: a review. Conservation Biol., 5. 18-32. 1990.

SCHIERHOLZ, T. Dinâmica Biológica de Fragmentos Florestais. Ciência Hoje. Vol. 12, no 71, março 1991. p. 24-9. 1991.

SOKAL, R.R. \& ODEN, N.L. Spatial autocorrelation in biology. 1. Methodology. Biol. J. Linn. Soc. 10: 199-228. 1978.

SOLTIS, D.E.; HAUFLER, C.H.; DARROW, D.C. \& GASTONY, G.L. Starch gel electrophoresis of ferns: a compilation of grinding buffers, gel and electrode buffers, and staining schedules. American Fern Journal, 73(1):9-26. 1983.

SWOFFORD, D.L. \& SELANDER, R.B. Biosys-1. A computer program for the analysis of allelic variation in population genetics and biochemical systematics. Release 1,7 Illino is Natural History Survey,. 1989. 
TEMPLETON, A. R. , SHAW, K. , ROUTMAN, E. \& DAVIS, S. K. The genetics consequences of habitat fragmentation. Ann. Missouri of Bot. Gard. 1990. 77 : 13 $-27$.

VIANA, V.M. Conservação da Biodiversidade de fragmentos de florestas tropicais em paisagens intensivamente cultivadas. In: Anais da Conferência Internacional: "on common ground: interdisciplinary approaches to biodiversity conservation and land use dynamics in the new world". Belo Horizonte. Brasil, 1995. p. 135-154.

WAHNSCHAFFE, A. Paineira branca. Primeiro Volume. São Paulo, setembro de 1931. 129p.

WEIR, B.S. Genetic data analysis: methods for discrete population genetic data. Sunderland, Sinawer Associates, Inc. Publishers, 1990. 377 p.

WILCOVE, D.S. From fragmentation to extinction. Natural Areas J., 7, 23-29. 1987.

WORKMAN, P. \& NISWANDER, J.L. Population studies on southwestern indeis tribes. II Local genetic differentiation in the Papago. Am. J. Hum. Genet., 22: 2449, 1970.

WRIGHT, S. The interpretation of population structure by F-statistics with special regard to systems of mating. Evolution, 19: 395-420, 1965.

WRIGHT, S. Evolution and the genetics of populations. Vol. 4. Variability within and among natural populations Chicago, Univ. of Chicago Press, 1978.

WRIGHT, S. The genetical structure of population. Annals of Eugenics V.15. p. 323354. 1951.

YOUNG, A.; BOYLE, T. \& BROWN, T. The population genetics consequences of habitat fragmentation for plants. Tree vol $11 \mathrm{n}$ o 10 . October 1996. 413-18.

YOUNG, A.G.; MERRIAN, H.G. \& WARWICK, S.I. The effects of forest fragmentation on genetic variation in Acer saccharum Marsh. (sugar maple) population. Heredity 71 (1993) 277-289. 